Portland State University

PDXScholar

7-7-1995

\title{
Synthesis and Characterization of Novel Fluorine Containing Alkylsulfonyls and Sulfonates: Fluorinated Sulfonyl Methanes and Derivatives
}

Nelson R. Holcomb

Portland State University

Follow this and additional works at: https://pdxscholar.library.pdx.edu/open_access_etds

Part of the Chemistry Commons

Let us know how access to this document benefits you.

\section{Recommended Citation}

Holcomb, Nelson R., "Synthesis and Characterization of Novel Fluorine Containing Alkylsulfonyls and Sulfonates : Fluorinated Sulfonyl Methanes and Derivatives" (1995). Dissertations and Theses. Paper 5055.

https://doi.org/10.15760/etd.6931

This Thesis is brought to you for free and open access. It has been accepted for inclusion in Dissertations and Theses by an authorized administrator of PDXScholar. Please contact us if we can make this document more accessible: pdxscholar@pdx.edu. 
THESIS APPROVAL

The abstract and thesis of Nelson R. Holcomb for the Master of Science degree in Chemistry was presented July 7, 1995 and accepted by the thesis committee and the department.

COMMITTEE APPROVALS:
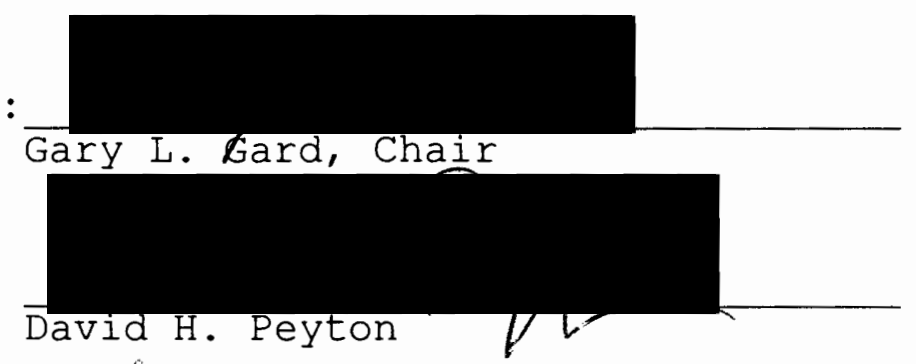

DEPARTMENT APPROVAL:
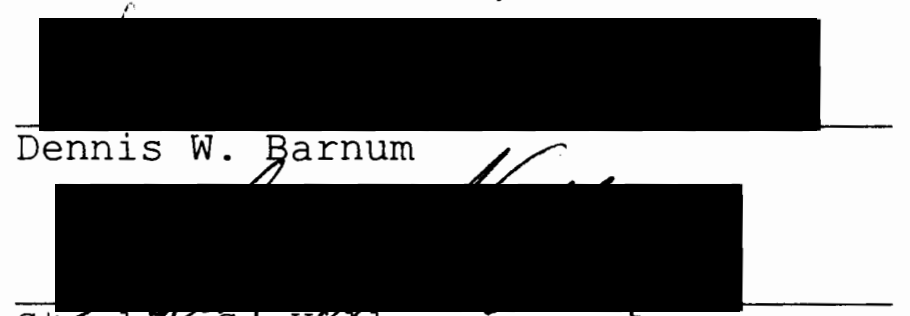

Stanley S: yylman

Representative of the office of Graduate Studies

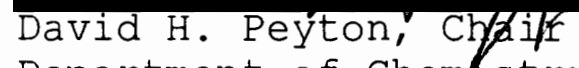

Department of Chemistry

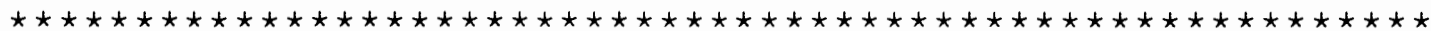

ACCEPTED FOR PORTLAND STATE UNIVERSITY BY THE LIBRARY bys on

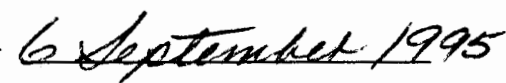


ABSTRACT

An abstract of the thesis of Nelson R. Holcomb for the Master of Science in Chemistry presented July 7, 1995. Title: Synthesis and Characterization of Novel Fluorine Containing Alkylsulfonyls and Sulfonates: Fluorinated Sulfonyl Methanes and Derivatives

A series of salts of the strong fluorocarbon acid bis(trifluoromethylsulfonyl)methane were made: $\left(\mathrm{CF}_{3} \mathrm{SO}_{2}\right)_{2} \mathrm{CHK}, \quad\left(\mathrm{CF}_{3} \mathrm{SO}_{2}\right)_{2} \mathrm{CHLi}, \quad\left[\left(\mathrm{CF}_{3} \mathrm{SO}_{2}\right)_{2} \mathrm{CH}\right]_{2} \mathrm{Ca}$, $\left[\left(\mathrm{CF}_{3} \mathrm{SO}_{2}\right)_{2} \mathrm{CH}\right]_{2} \mathrm{Hg}, \quad\left(\mathrm{CF}_{3} \mathrm{SO}_{2}\right)_{2} \mathrm{CHAg}, \quad\left[\left(\mathrm{CF}_{3} \mathrm{SO}_{2}\right)_{2} \mathrm{CH}\right]_{3} \mathrm{La}$. Their reactivity and use as organic intermediates were investigated. The salts were made from their corresponding carbonates, oxides, or hydrides. The reaction times for the salts is generally short, however the purification process was laborious, involving recrystallization from organic solvents and drying under vacuum. The lithium salt is being evaluated as a solid state battery electrolyte.

Derivatives of bis(trifluoromethylsulfonyl)methane were made by using the salts as nucleophiles in organic reactions. Reactions with $\mathrm{Br}_{2}, \mathrm{CH}_{2}=\mathrm{CH}_{2} \mathrm{CH}_{2} \mathrm{Br}, \mathrm{CH}_{3} \mathrm{CH}_{2} \mathrm{CH}_{2} \mathrm{I}$, and $\mathrm{OCH}_{2} \mathrm{CHCH}_{2} \mathrm{Br}$ were carried out to make: 
bis (trifluormethylsulfonyl) bromomethane,

4, 4-bis(trifluormethylsulfonyl) butene-1,

1,1-bis (trifluormethylsulfonyl)butane, and

4,4-bis(trifluormethylsulfonyl)-1,3-epoxybutane

In addition, work was carried out on the synthesis

of the polymer $-\left(-\mathrm{O}-\mathrm{CH}_{2}-\mathrm{C}\left(\mathrm{CH}_{2} \mathrm{OCF}_{2} \mathrm{CF}_{2} \mathrm{SO}_{2} \mathrm{~F}\right) \mathrm{H}-\right)_{\mathrm{n}}-$ and the corresponding lithium salt. The polymer was treated with aqueous lithium hydroxide in order to convert the $\mathrm{SO}_{2} \mathrm{~F}$ group to a $\mathrm{SO}_{3}{ }^{-} \mathrm{Li}^{+}$group. This salt is being investigated as a solid state ion conducting polymer.

All products were characterized by infrared spectroscopy, mass spectroscopy, ${ }^{1} \mathrm{H}$ and ${ }^{19} \mathrm{~F}$ nuclear magnetic resonance spectroscopy, elemental analysis, and melting points. 
SYNTHESIS AND CHARACTERIZATION OF

NOVEL FLUORINE CONTAINING ALKYLSULFONYLS AND

SULFONATES: FLUORINATED SULFONYL METHANES

AND DERIVATIVES

by

NELSON R. HOLCOMB

A thesis submitted in partial fulfillment of the requirements for the degree of

MASTER OF SCIENCE

in

CHEMISTRY

Portland State University

1995 


\section{ACKNOWLEDGMENTS}

I wish to express my appreciation of my research advisor, Dr. Gary L. Gard; he was a support to my research and that of the research group as a whole and he provided valuable insight to the group as a whole and kept our work moving on. His willingness to proceed after the subject at hand provided the impetus to complete my research.

I would like to thank Dr. Nicolas N. Hamel and Steven A. Ullrich for the time they spent showing me the techniques and methods employed in the laboratory. Dr. Rolf winter provided many innovative ideas and solutions to questions about technique and analogous reactions.

Dr. Fred E. Behr of 3M Company is to be thanked for his generous gift of fluorinated chemical samples.

Dr. David Grainger and his research group at Colorado State University gave invaluable aid in running mass spectra.

My wife Jenene has persevered through this project and provided me with support and encouragement. 
Table of Contents

PAGE

ACKNOWLEDGMENTS $\ldots \ldots \ldots \ldots \ldots \ldots \ldots \ldots \ldots \ldots \ldots \ldots \ldots \ldots \ldots \ldots$

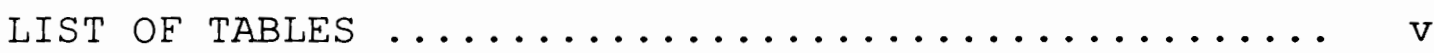

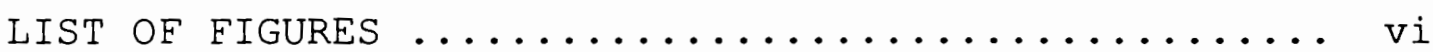
CHAPTER

I INTRODUCTION $\ldots \ldots \ldots \ldots \ldots \ldots \ldots \ldots \ldots \ldots$

I I POLYMER ELECTROLYTES $\ldots \ldots \ldots \ldots \ldots \ldots \ldots \ldots$

IONOMERS $\ldots \ldots \ldots \ldots \ldots \ldots \ldots \ldots \ldots \ldots$

LITHIUM BATTERIES ............. 14

II CHEMISTRY OF $\left(\mathrm{CF}_{3} \mathrm{SO}_{2}\right)_{2} \mathrm{CH}_{2} \ldots \ldots \ldots \ldots \ldots \ldots \ldots \ldots \ldots$

FLUOROCARBON ACIDS $\ldots \ldots \ldots \ldots \ldots \ldots \ldots$

SYNTHESIS OF $\left(\mathrm{CF}_{3} \mathrm{SO}_{2}\right){ }_{2} \mathrm{CH}_{2} \ldots \ldots \ldots \ldots \ldots$

SYNTHESIS OF DERIVATIVES .......... 24

INDUSTRIAL APPLICATIONS $\ldots \ldots \ldots \ldots \ldots 27$

IV EXPERIMENTAL METHODS .............. 29

VACUUM LINES ................ 29

REACTION VESSELS ................. 30

INSTRUMENTATION $\ldots \ldots \ldots \ldots \ldots \ldots \ldots \ldots$

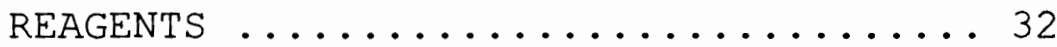

$\mathrm{V}$ TRIFLUOROMETHYLSULFONYL SYSTEMS $\ldots \ldots \ldots \ldots 34$

GENERAL SYNTHESIS ROUTES ............ 34

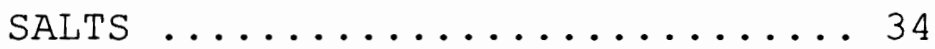

$\alpha$-HALOGEN DISULFONES $\ldots \ldots \ldots \ldots 36$

SUMMARY $\ldots \ldots \ldots \ldots \ldots \ldots \ldots \ldots \ldots \ldots \ldots \ldots \ldots \ldots \ldots \ldots$

INERARED SPECTRA ............. 44

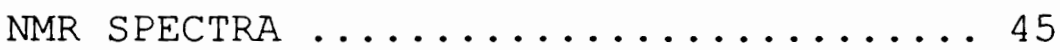

MASS SPECTRA ............... 47

ELEMENTAL ANALYSIS $\ldots \ldots \ldots \ldots \ldots \ldots \ldots$

VI SYNTHESIS OF $\left(\mathrm{CF}_{3} \mathrm{SO}_{2}\right)_{2} \mathrm{CH}_{2}$ SALTS $\ldots \ldots \ldots \ldots \ldots$

SYNTHESIS OF $\left(\mathrm{CF}_{3} \mathrm{SO}_{2}\right){ }_{2} \mathrm{CH}^{-}{ }^{+} \mathrm{K} \ldots \ldots \ldots 56$

SYNTHESIS OF $\left(\mathrm{CF}_{3} \mathrm{SO}_{2}\right)_{2} \mathrm{CH}^{-}{ }^{+} \mathrm{Li} \ldots \ldots \ldots 56$

SYNTHESIS OF $\left[\left(\mathrm{CF}_{3} \mathrm{SO}_{2}\right)_{2} \mathrm{CH}\right]_{2}{ }^{2-}{ }^{2+} \mathrm{Ca} \ldots .57$ 
SYNTHESIS OF $\left[\left(\mathrm{CF}_{3} \mathrm{SO}_{2}\right)_{2} \mathrm{CH}\right]_{2}{ }^{2-}{ }^{2+} \mathrm{Hg} \ldots \ldots 58$ SYNTHESIS OF $\left(\mathrm{CF}_{3} \mathrm{SO}_{2}\right)_{2} \mathrm{CHBr} \ldots \ldots \ldots \ldots 58$ SYNTHESIS $O \mathrm{OF}_{2} \mathrm{Ag}_{2} \mathrm{CO}_{3} \ldots \ldots \ldots \ldots \ldots \ldots$ SYNTHESIS OF $\left(\mathrm{CF}_{3} \mathrm{SO}_{2}\right)_{2} \mathrm{CH}^{-}{ }^{+} \mathrm{Ag} \ldots \ldots \ldots 60$ SYNTHESIS OF $\left[\left(\mathrm{CF}_{3} \mathrm{SO}_{2}\right)_{2} \mathrm{CH}\right]_{3}{ }^{3-}{ }^{3+} \mathrm{La} \ldots .61$ SYNTHESIS OF $\left(\mathrm{CF}_{3} \mathrm{SO}_{2}\right)_{2} \mathrm{CHCH}_{2} \mathrm{CH}=\mathrm{CH}_{2} \ldots \ldots 61$ SYNTHESIS OF $\left(\mathrm{CF}_{3} \mathrm{SO}_{2}\right)_{2} \mathrm{CHCH}_{2} \mathrm{CH}_{2} \mathrm{CH}_{3} \ldots \ldots 62$ SYNTHESIS OF AgF .............6 63 SYNTHESIS OF $\mathrm{FSO}_{2} \mathrm{CF}_{2} \mathrm{CF}_{2} \mathrm{OCH}_{2} \mathrm{CHCH}_{2} \mathrm{O} \quad \ldots .64$ SYNTHESIS OF $\left(\mathrm{CF}_{3} \mathrm{SO}_{2}\right)_{2} \mathrm{CHCH}_{2} \mathrm{CHCH}_{2} \mathrm{O} \quad \ldots \ldots 65$

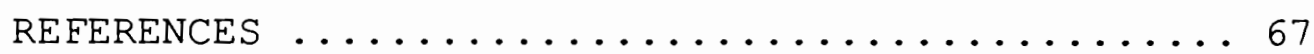

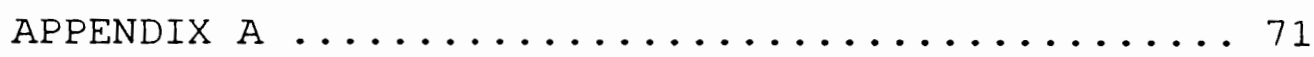
INFRARED SPECTRA $\ldots \ldots \ldots \ldots \ldots \ldots \ldots 71$ 


\section{List of Tables}

TABLE

PAGE

1 POLY (ETHYLENE OXIDE) II SALT COMPLEXES ....... 8

2 A COMPARATIVE LISTING OF OTHER

CONDUCTIVE POLYMERS .................. 8

3 SUMMARY OF COMPOUNDS SYNTHESIZED .......... 41

4 CHARACTERISTIC INFRARED ABSORPTION

FREQUENCIES ..................... 44

5 CHARACTERISTIC NMR RESONANCES ........... 46

6 MASS SPECTRA DATA .................. 48

7 ELEMENTAL ANALYSIS .................. 52 
List of Figures

FIGURE

PAGE

1 STRUCTURE OF UDEL P-1700 AND

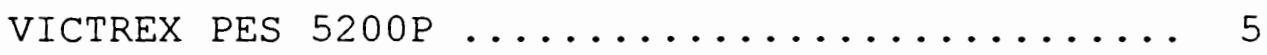

2 STRUCTURE OF THIOPHENOPHANE POLYMER ......... 7

3 NAFION IONOMER ...................... 9

4 ELECTRODE REACTIONS OE A LITHIUM BATTERY ..... 14

5 STRUCTURE OF POLY (ETHYLENE OXIDE) ......... 16

6 STRUCTURE OF ETHYLENEBIS (OXYETHYLENENITRILO)

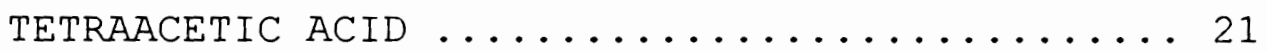

7 STRUCTURE OF $\left(\mathrm{CF}_{3} \mathrm{SO}_{2}\right){ }_{2} \mathrm{CH}_{2}, \quad\left(\mathrm{CF}_{3} \mathrm{SO}_{2}\right){ }_{2} \mathrm{CH}^{-}$ WITH METAL COORDINATED TO OXYGENS AND $\left(\mathrm{CE}_{3} \mathrm{SO}_{2}\right)_{2} \mathrm{CH}^{-}$WITH A METAL-CARBON BOND ........ 22

8 ANALOGOUS STRUCTURES OF HINDERED ALCOHOLS .... 54

9 IR Spectra of $\left.\left[\left(\mathrm{CF}_{3} \mathrm{SO}_{2}\right)_{2} \mathrm{CH}\right)\right]_{2} \mathrm{Hg}$ salt ......... 72

10 IR Spectra of $\left(\mathrm{CF}_{3} \mathrm{SO}_{2}\right)_{2} \mathrm{CHCH}_{2} \mathrm{CH}=\mathrm{CH}_{2} \ldots \ldots \ldots \ldots$

11 IR spectra of $\left(\mathrm{CF}_{3} \mathrm{SO}_{2}\right)_{2} \mathrm{CHBr} \ldots \ldots \ldots \ldots \ldots \ldots$

12 IR Spectra of $\left(\mathrm{CF}_{3} \mathrm{SO}_{2}\right)_{2} \mathrm{CH}_{2} \ldots \ldots \ldots \ldots \ldots$

13 IR Spectra of $\left(\mathrm{CF}_{3} \mathrm{SO}_{2}\right)_{2} \mathrm{CHLi} \ldots \ldots \ldots \ldots \ldots$ 
14 IR Spectra of $\left(\mathrm{CF}_{3} \mathrm{SO}_{2}\right)_{2} \mathrm{CHAg} \ldots \ldots \ldots \ldots \ldots \ldots \ldots$

15 IR Spectra of $\left.\left[\left(\mathrm{CF}_{3} \mathrm{SO}_{2}\right)_{2} \mathrm{CH}\right)\right]_{2} \mathrm{Ca} \ldots \ldots \ldots \ldots \ldots \ldots$

16 IR Spectra of $\left(\mathrm{CF}_{3} \mathrm{SO}_{2}\right)_{2} \mathrm{CHCH}_{2} \mathrm{CH}_{2} \mathrm{CH}_{3} \ldots \ldots \ldots \ldots 79$

17 IR Spectra of $\left(\mathrm{CF}_{3} \mathrm{SO}_{2}\right)_{2} \mathrm{CHCH}_{2} \mathrm{CH}(\mathrm{OH}) \mathrm{CH}_{2} \mathrm{Cl} \ldots \ldots .80$

18 IR Spectra of $\left.\left[\left(\mathrm{CF}_{3} \mathrm{SO}_{2}\right)_{2} \mathrm{CH}\right)\right]_{2} \mathrm{Zn} \ldots \ldots \ldots \ldots \ldots$

19 IR Spectra of $\left.\left[\left(\mathrm{CF}_{3} \mathrm{SO}_{2}\right)_{2} \mathrm{CH}\right)\right]_{3} \mathrm{La} \ldots \ldots \ldots \ldots \ldots .62$

20 IR Spectra of $\left(\mathrm{CF}_{3} \mathrm{SO}_{2}\right)_{2} \mathrm{CBrK} \ldots \ldots \ldots \ldots \ldots \ldots$

21 IR Spectra of $\left.\left(\mathrm{CF}_{3} \mathrm{SO}_{2}\right)_{2} \mathrm{CH}(\mathrm{HgBr})\right] \ldots \ldots \ldots \ldots .64$

22 IR Spectra of $\mathrm{ESO}_{2} \mathrm{CF}_{2} \mathrm{CF}_{2} \mathrm{OCH}_{2} \mathrm{CHCH}_{2} \ldots \ldots \ldots \ldots .65$ 
Chapter 1

\section{Introduction}

The purpose of this work was to investigate the synthesis and uses of the following:

(I) $\left(\mathrm{CF}_{3} \mathrm{SO}_{2}\right)_{2} \mathrm{CH}_{2}$ and its salts

(a) For use as new Li electrolytes.

$$
\begin{aligned}
& \text { (i) }\left(\mathrm{CF}_{3} \mathrm{SO}_{2}\right){ }_{2} \mathrm{CH}^{-} \mathrm{Li}^{+} \text {and } \\
& \text { (ii) }\left(\mathrm{CF}_{3} \mathrm{SO}_{2}\right){ }_{2} \mathrm{CF}^{-} \mathrm{Li}^{+}
\end{aligned}
$$

(b) To study the chemistry of $\left(\mathrm{CF}_{3} \mathrm{SO}_{2}\right)_{2} \mathrm{CH}_{2}$ and its derivatives.

(II) Novel new epoxide monomers for use as Li-polymer electrolytes
,
(a) $\mathrm{CH}_{2} \mathrm{CHCH}_{2} \mathrm{OCF}_{2} \mathrm{CF}_{2} \mathrm{SO}_{2} \mathrm{O}^{-} \mathrm{Li}^{+}$
(b) $\left[\begin{array}{c}\mathrm{O} \\ \mathrm{CH}_{2} \mathrm{CHCH}_{2} \mathrm{C}\left(\mathrm{SO}_{2} \mathrm{CF}_{3}\right)_{2}\end{array}\right]^{-} \mathrm{K}^{+}$

What follows in this thesis is a literature review of (I) polymer electrolytes (Chapter 2), and (II) $\left(\mathrm{CF}_{3} \mathrm{SO}_{2}\right){ }_{2} \mathrm{CH}_{2}$ and its derivatives and uses (Chapter 3). Chapter 4 gives the experimental methods used in this study. Chapter 5 is a discussion of the research results as reported in Chapter 6 , the experimental results. 
Chapter 2

\section{Polymer Electrolytes}

There are two major types of polymer electrolytes which are receiving attention:

I Polymer/lithium salt blends, and

II Polymers containing a pendant ionic salt group.

Both of these electrolyte types can be polylethylene oxide) (PEO) based systems. The use of PEO based polymer systems is motivated by some of the characteristics of the PEO systems: ${ }^{1}$

1. they have little or no crystallinity,

2. they have amorphous regions to aid in conductivity,

3. they show good solvating properties toward lithium,

These characteristics are advantageous to polymer electrolyte performance and have led to the use of PEO 
based systems on a wide scale. Typically PEO is mixed with a salt, containing at least one strong electron withdrawing group, in a suitable organic solvent and cast in glass rings on poly(tetrafluoroethylene) (PTFE) plates or onto PTEE dishes. The main reason for the salt is to lower the crystallinity of the PEO polymers, which would lower the melting point and the glass-transition temperature of the complex; also this would slow the rate of crystallization if any remained in the complex. This is important because conductivity is primarily accomplished through the amorphous phase. ${ }^{2}$

Many oxygen containing polymers exhibit electrical conductivity; the scope of this review will be restricted to a historical review of conductive polymers and a discussion of conductivity in poly (ethylene oxide) derivatives and salt complexes. Some conductivity values are given in Table 1 . This is a small representative group of $\mathrm{PEO} / \mathrm{salt}$ polymer complexes that conduct ions. Most of these complexes are being investigated for use as ion conducting electrolytes in batteries.

There is ongoing research investigating the use of a polymeric solvent in place of other non-aqueous solvents currently used in rechargeable batteries. ${ }^{3}$ one polymer system that has been a focus of research in this laboratory is based on $\mathrm{OCH}_{2} \mathrm{CHCH}_{2} \mathrm{OCF}_{2} \mathrm{CF}_{2} \mathrm{SO}_{2} \mathrm{~F}$. This monomer 
can be polymerized and the $\mathrm{SO}_{2} \mathrm{~F}$ group can be converted to an $-\mathrm{SO}_{3}{ }^{-} \mathrm{Li}^{+}$group. This polymer shows great promise as a surface coating in its $\mathrm{SO}_{2} \mathrm{~F}$ form because of surface enrichment in fluorine. ${ }^{4}$ This enrichment provides a coating that has the surface properties of a fluoropolymer and the durability and adhesion characteristics of a hydrocarbon polymer. This has been shown by $x$-ray photoelectron spectroscopy studies done on $\mathrm{OCH}_{2} \mathrm{CHCH}_{2} \mathrm{OCF}_{2} \mathrm{CF}_{2} \mathrm{SO}_{2} \mathrm{~F}$ copolymerized with the diepoxide $\underset{\mathrm{C}}{\mathrm{CH}_{2} \mathrm{CHCHCH}_{2} \mathrm{CH}_{2} \mathrm{CHOCCHCH}} \underset{2}{\mathrm{CHCHCH}_{2} \mathrm{CH}_{2}}$

It should be noted that the sulfonate group $\left(\mathrm{SO}_{3}{ }^{-} \mathrm{M}^{+}\right)$ can act as a very efficient ion exchange functional group. It is stable toward water and many organic solvents; thus it is therefore suitable for use in many environments that would be hostile to carboxylic acid or phosphoric acid groups. When combined with a perfluorinated polymer, the strength and durability of the ion exchange membrane can be greatly increased.

Proton conducting polymers could be used as a membrane material for modern energy conversion technologies, ie. fuel cells or lithium batteries. Polymers that carry a sulfonic acid substituent can assist the diffusion of protons through the polymer matrix. Sulfonated poly(arylene ether sulfones) with various sulfonation levels have been evaluated as solid polymer 
electrolytes in electrolysers and fuel cells. Commercial products Udel ${ }^{\circledR}$ P-1700 and Victrex ${ }^{\circledR}$ PES $5200 \mathrm{P}$ were sulfonated, by treatment with chlorotrimethylsilane followed by chlorosulfonic acid, incorporating up to 90 molo, yielding polyelectrolytes that have been characterized, the structures of $\mathrm{Udel}^{\circledR} \mathrm{P}-1700$ and Victrex ${ }^{\circledR}$ PES 5200P are shown in Figure 1.

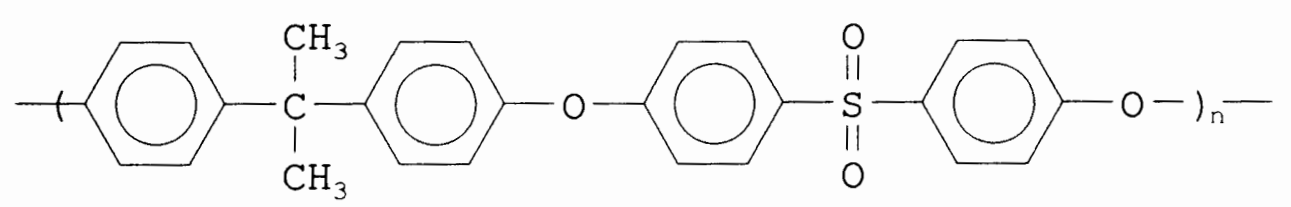

a) Udell P-1700

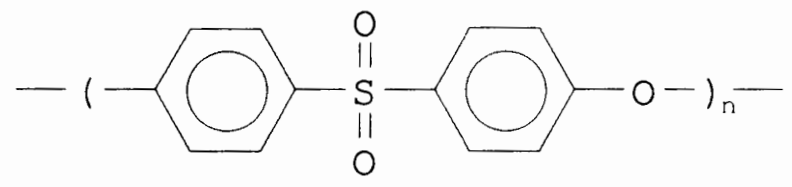

b) Victrex $5200 \mathrm{P}$

Figure 1: Structure of a) Udel ${ }^{\circledR}$ P-1700 and b) Victrex ${ }^{\circledR}$ PES 5200P

The electrochemical properties of these modified materials were similar to those for fluorine-containing polyelectrolytes used in commercial membrane systems for production of high purity of alkali or caustic soda. 5 one advantage that the partially sulfonated poly(arylene sulfones) have is that they can be crosslinked during the membrane processing step, by anodic coupling of the 
activated methylene groups between the sulfones, 6 reducing the amount of water swelling that occurs during use. These sulfonated polymers and others like them are designated as ionomers and will be discussed in the next section of this manuscript.

The use of polymers as ion conductive materials is not new, however the materials that are currently being used are unique as compared to the materials of the past. An interesting material can be produced by having the monomers assembled in a highly ordered packing, the conductivity and optical properties can be tailor-made specific to an application. An illustration of this is a polymer which has an asymmetric orientation of the monomer units, resulting in a phenomenon known as anisotropic electrical conductivity; the electrical conductivity parallel to the aligned polymer chains is greater than that through the film. ${ }^{7}$ Sulfonate monomers that have appropriate alkyl side chain length (octyl to tetradecyl) will form micelles in aqueous solution and these polymers can be cast as lamellar, semicrystalline thin films. $x-$ ray diffraction studies of these polymers show that the most likely arrangement is a head-to-head bilayer type packing. The repeat unit of the semicrystalline polymer corresponds to twice the extended length of the monomer, and each additional methylene unit in the hydrophobic 
alkyl chain adds approximately 2 angstroms to the interlayer spacing. By altering the interlayer spacing, done by controlling the length of the alkyl chain, the conductivity can be tailored to a specific application. This type of polymer can possibly be used in the electronics industry as a synthetic metal or as a resistor in circuits.

There are other polymer systems that conduct electricity without moving ions, and these will be discussed in order to contrast the PEO complexes; some conductivity values for these systems are given in Table 2. Nonconjugated organic polymers are generating interest since some have shown conductivities of $0.1(\Omega \mathrm{cm})^{-1}$. An example of this type of polymer is $\operatorname{poly}((E, E)-[6.2]-$ $(2,5)$ thiophenophane-1,5-diene) which polymerizes to give a polymer (Figure 2) that has bridged thiophene rings pendant to the polymer backbone. Doping by iodine is necessary for electrical conduction, but exposure to iodine vapor is sufficient to saturate the polymer.

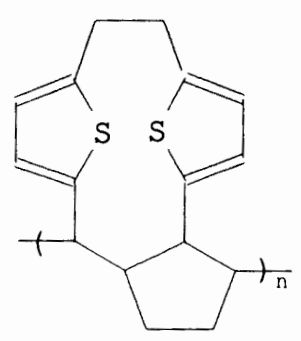

Figure 2: Structure of thiophenophane polymer 
Table 1

PEO Li salt Complexes

\begin{tabular}{|llll|}
\hline Counterion & Ref & $\begin{array}{l}\text { PEO:Li+ } \\
\text { Ratio }\end{array}$ & $\begin{array}{l}\text { Conductivity } \\
\left(\Omega^{-1} \mathrm{Cm}^{-1}\right)\end{array}$ \\
\hline $\mathrm{ClO}_{4}{ }^{-}$ & 8 & $16: 1$ & $2 \times 10^{-4}(373 \mathrm{~K})$ \\
$\mathrm{CF}_{3} \mathrm{SO}_{3}^{-}$ & 9 & $9: 1$ & $4 \times 10^{-4}(373 \mathrm{~K})$ \\
$\mathrm{CH}_{3} \mathrm{COO}^{-}$ & 9 & $5 \times 10^{-4}(403 \mathrm{~K})$ \\
$\mathrm{CF}_{3} \mathrm{COO}^{-}$ & 9 & $9: 1$ & $2.9 \times 10^{-4}(409 \mathrm{~K})$ \\
$\mathrm{CF}_{3} \mathrm{CF}_{2} \mathrm{CF}_{2} \mathrm{COO}^{-}$ & 9 & $9: 1$ & $1.5 \times 10^{-4}(409 \mathrm{~K})$ \\
$\mathrm{OOC}_{(}\left(\mathrm{CF}_{2}\right){ }_{3} \mathrm{COO}^{-}$ & 9 & $9: 1$ & $4.7 \times 10^{-5}(409 \mathrm{~K})$ \\
$\left(\mathrm{CF}_{3} \mathrm{SO}_{3}\right)_{2} \mathrm{~N}^{-}$ & 10 & $8: 1$ & $3.1 \times 10^{-3}(353 \mathrm{~K})$ \\
$\left(\mathrm{CF}_{3} \mathrm{SO}_{3}\right){ }_{3} \mathrm{C}^{-}$ & 11 & $10: 1$ & $2 \times 10^{-3}(353 \mathrm{~K})$ \\
$\mathrm{SCN}^{-}$ & 12 & $5: 1$ & $7 \times 10^{-4}(393 \mathrm{~K})$ \\
$\mathrm{Br}^{-}$ & 12 & $4.5: 1$ & $1 \times 10^{-5}(423 \mathrm{~K})$ \\
$\mathrm{BF}_{4}^{-}$ & 12 & $4.5: 1$ & $1 \times 10^{-5}(293 \mathrm{~K})$ \\
\hline
\end{tabular}

Table 2

A Comparative Listing of other conductive polymers ${ }^{13}$

\begin{tabular}{|c|c|c|}
\hline Polymer & $\begin{array}{l}\text { Dopant } \\
\text { Material }\end{array}$ & $\begin{array}{l}\text { Conductivity } \\
\left(\Omega^{-1} \mathrm{~cm}^{-1}\right)\end{array}$ \\
\hline Polyacetylene & $\begin{array}{ll}\mathrm{I}_{2}, & \mathrm{Br}_{2}, \mathrm{Li}, \\
& \mathrm{Na}, \mathrm{AsF}_{5} \\
\end{array}$ & 10,000 \\
\hline Polypyrrole & $\begin{array}{c}\mathrm{BF}_{4}^{-}, \mathrm{ClO}_{4}^{-}, \\
\text {tosylate }\end{array}$ & $500-7500$ \\
\hline Polythiophene & $\begin{array}{l}\mathrm{BF}_{4}^{-}, \mathrm{ClO}_{4}^{-}, \\
\text {tosylate, } \mathrm{FeCl}_{4}^{-}\end{array}$ & 1000 \\
\hline $\begin{array}{l}\text { Poly }(3-a l k y l \\
\text { thiophene) }\end{array}$ & $\begin{array}{l}\mathrm{BE}_{4}^{-}, \mathrm{ClO}_{4}^{-}, \\
\mathrm{FeCl}_{4}^{-}\end{array}$ & $1000-10,000$ \\
\hline
\end{tabular}




\section{IONOMERS}

Because of the chemical and thermal stability of fluoropolymers, much research has been focused on them. Ionomers are defined as polymers containing low concentrations $\left(10\right.$ to 15 mole $\left.\frac{0}{0}\right)$ of ions, while polymers that have very high concentrations of ions are referred to as polyelectrolytes. Most ionomers are produced by the copolymerization of monomers containing ionic functional groups with ethylene, 14 styrene, 15 monomers of rubber, 16 or tetrafluoroethylene (TFE). 17 Ionomers generally refer to polymers which have their ionic unit on a side chain, while ionenes refer to polymers which have ionic units on their backbone. ${ }^{18}$ Two commercially successful ionomers are Nafion (Figure 3) and Surlyn. Since these two were developed, considerable research has focused on ionomers.

$$
\begin{aligned}
& -\left(\mathrm{CF}_{2} \mathrm{CF}_{2}\right)_{\times}\left(\mathrm{CF}_{2} \mathrm{CF}\right)_{\bar{v}} \\
& \left(\mathrm{OCFCF}_{2}\right)_{\mathrm{n}} \mathrm{O} \mathrm{CF}_{2} \mathrm{CF}_{2} \mathrm{SO}_{3} \mathrm{H} \\
& \mathrm{CF}_{3}
\end{aligned}
$$

Figure 3: Nafion ${ }^{19}$ Ionomer ( $M=H$, alkali metals) 
The perfluorinated ionomer Nafion was produced by DuPont Co. in the 1960's by the following series of six reactions. 20,21 .

$$
\mathrm{F}_{2} \mathrm{C}=\mathrm{CF}_{2}+\mathrm{SO}_{3} \longrightarrow \underset{\substack{\mathrm{F}_{2} \mathrm{C}-\mathrm{P}_{2} \\ \mathrm{O}-\mathrm{SO}_{2}}}{\mathrm{CF}_{2}} \longrightarrow \mathrm{CsF} \mathrm{Cs}^{+-} \mathrm{OCF}_{2} \mathrm{CF}_{2} \mathrm{SO}_{2} \mathrm{~F}
$$

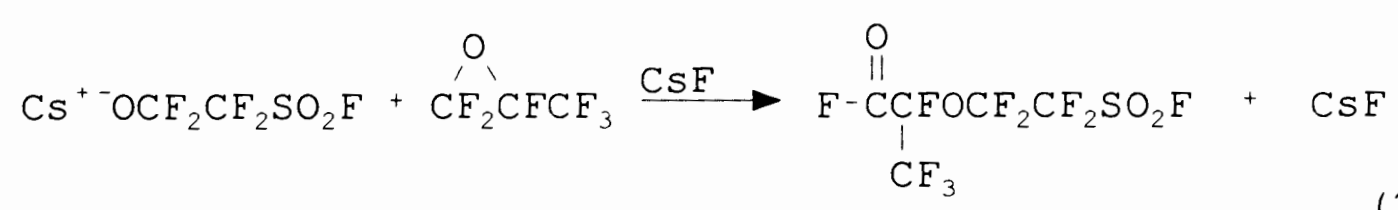

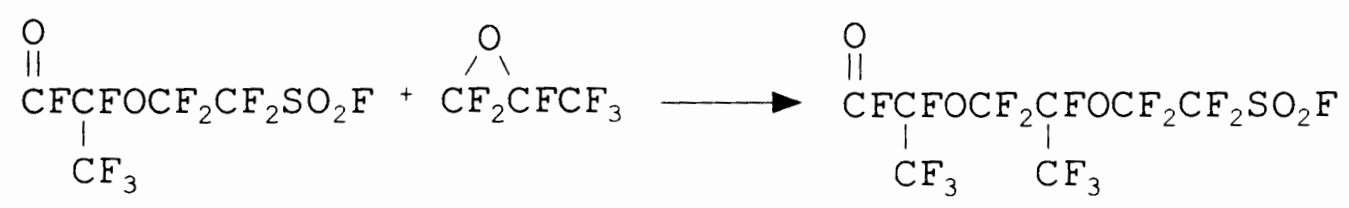

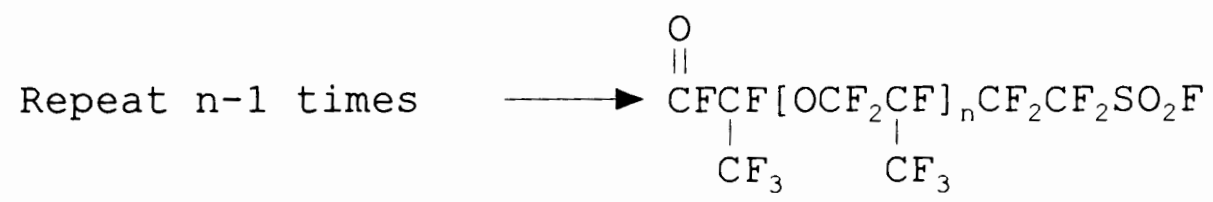

Typically this reaction is repeated six or seven times for Nafion manufacture.

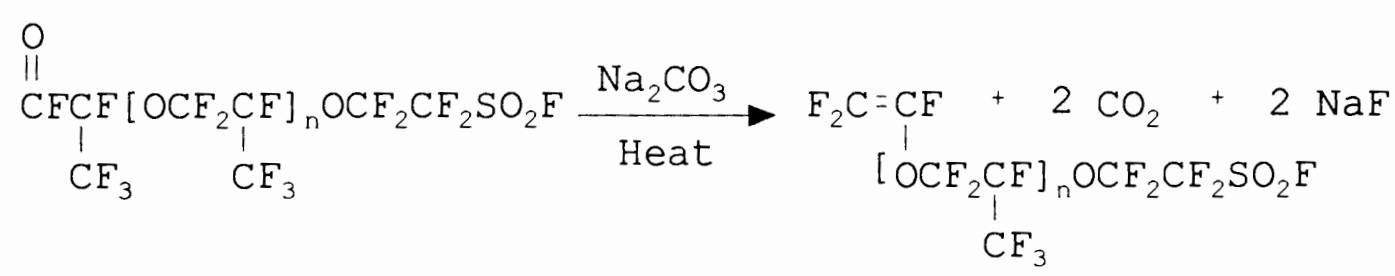

After forming the vinyl ether by heating with sodium carbonate the telomer can be copolymerized with tetrafluoroethylene under free-radical conditions 
producing the sulfonyl fluoride form of Nafion, the sulfonate is formed by treatment with base.

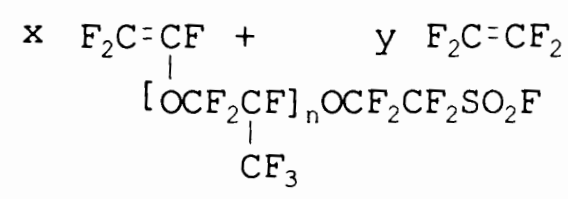

Ionomers exhibit ion aggregation, in liquid media of low dielectric constant or the dry state, ionomers are assumed to contain ion pairs and multiplets (groups of ion pairs at low ion concentration). At higher concentration the ions form clusters at a critical concentration. ${ }^{22}$ Both hydrocarbon and perfluorinated ionomers exhibit this characteristic. 22 In ionomer membranes there are three distinct regions: a microcrystalline region, the amorphous phase and the ionic clusters. Two models to explain ion clustering have been proposed, 23 one model has the ion clusters homogeneously distributed through the matrix ions, while the other model has the ion clusters shielded from surrounding matrix ions by a shell of hydrocarbon or fluorocarbon chains. Whichever model is correct, the influence of ion clustering on the glass transition temperature $\left(T_{g}\right), 24$ mechanical, diffusion, and other properties is considerable and should not be discounted.

Nafion and perfluorinated carboxylate ionomers 25,26 are two types of ionomers that have been thoroughly 
investigated. When in the salt form both ionomers exhibit ion ciustering. However they differ in the ion cluster characteristics. In the case of the Nafion, a perfluorinated sulfonate ionomer, the ion clusters have incomplete phase separation and contain three phases: the fluorocarbon phase, the ion cluster phase, and the interfacial region between these two phases. ${ }^{27}$ The interfacial region contains the pendant side chains, small amounts of adsorbed water, a small amount of the sulfonate exchange sites that have not been incorporated into clusters, and some counter ions. On the other hand the perfluorinated carboxylate ionomers have complete phase separation, having only two phases: the fluorocarbon phase and the ion clustering regions. ${ }^{28}$ The ion clusters in the perfluorinated carboxylate ionomers are thought to be larger and longer than in the perfluorinated sulfonate ionomer. Thus the ion diffusion pathway in the perfluorinated sulfonate ionomer would be more convoluted than the perfluorinated carboxylate ionomer. Therefore the functional groups on the ionomer can alter the characteristics of the ion clusters and can lead to large differences in the polymeric properties.

One aspect of this research has been to prepare new acidic ionic polymers or ion pairs for use in lithium batteries, or as a proton exchange membrane (PEM) in fuel 
cells. The acidic ionic polymer would be used as an electrolyte, and thus must be able either to conduct ions or allow diffusion of water and hydronium ions across the membrane. 


\section{LITHIUM BATTERIES}

Batteries are of interest because they offer a convenient and safe method to transport and store electrical energy. But most batteries do not produce the energy that is needed to power most applications except for a short period of time. A battery that uses lithium metal at the anode would be superior to standard storage batteries, both in the voltages produced and overall battery mass. If a polymer could be found that would readily transport Iithium ions with a conductivity greater than $10^{-4}(\Omega \mathrm{cm})^{-1}$, a battery could be made that uses this polymer as the electrolyte. 29 The half-reactions of a typical lithium battery are shown in Figure 4.

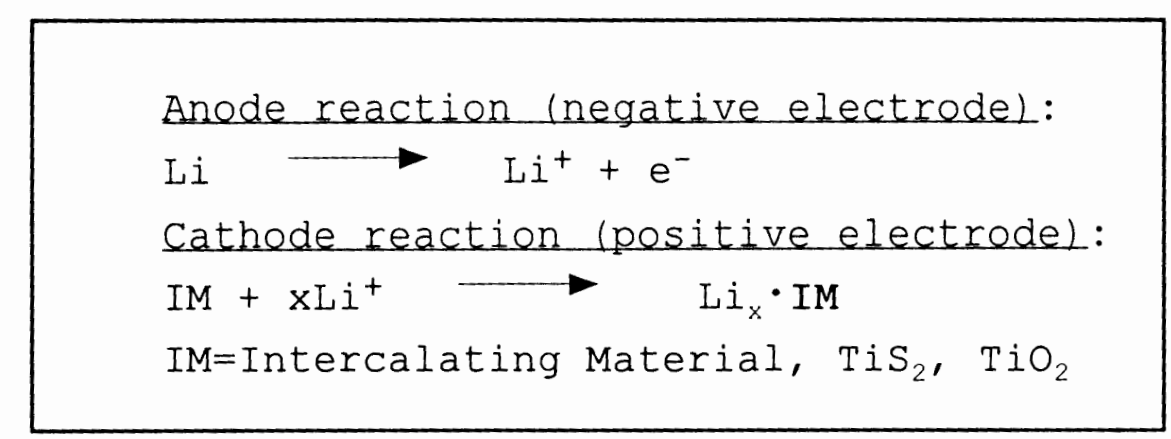

Figure 4: Electrode Reactions of a Lithium Battery

Polymer membranes are of particular interest because of their potential to conduct ions. Studies have shown PEO can conduct ions with conductivities $>10^{-3}(\Omega \mathrm{cm})^{-1}$ when cast with some lithium salts, $\left(\mathrm{CF}_{3} \mathrm{SO}_{2}\right){ }_{3} \mathrm{C}^{-} \mathrm{Li}^{+}$and 
$\left(\mathrm{CF}_{3} \mathrm{SO}_{2}\right)_{2} \mathrm{~N}^{-} \mathrm{Li}^{+} .11$ Membranes which contain the difunctional perfluoroalkane sulfonic acid, $\mathrm{HSO}_{3}\left(\mathrm{CF}_{2}\right)_{n} \mathrm{SO}_{3} \mathrm{H}$, and the corresponding lithium salts have shown promise as both fuel cell electrolytes and as ion conductors. 30

Studies of solid polymer electrolytes for use as ion transport media have focused on the use of poly-ethers, particularly the use of PEO, combined with alkali metal salts. Poly-ethers have solvating characteristics that other polymers do not have; they can readily solvate cations because of the unshared pairs of electrons on the oxygen. There is an optimum ratio of carbon atoms to oxygen atoms as evidenced by the fact that poly(methylene oxide) $-\left(\mathrm{CH}_{2}-\mathrm{O}\right)$ - and poly(tetrahydrofuran) do not conduct ions as well as PEO. 12

PEO complexes were the first polymer electrolyte system reported that was free of any solvent. The mechanism for conduction seems to be that the cation from a salt dissolved in the solvating polymer coordinates to the electron pairs on the oxygen. Pure PEO has a helical structure with seven monomer units in each unit cell. The unit cell has a length of 19.3 Angstroms (Figure 5). The charge on the Iithium is balanced in the helix by a negative charge on a polymer pendant group or an immobile anion outside the helix, typically a sulfonate. ${ }^{31}$ 


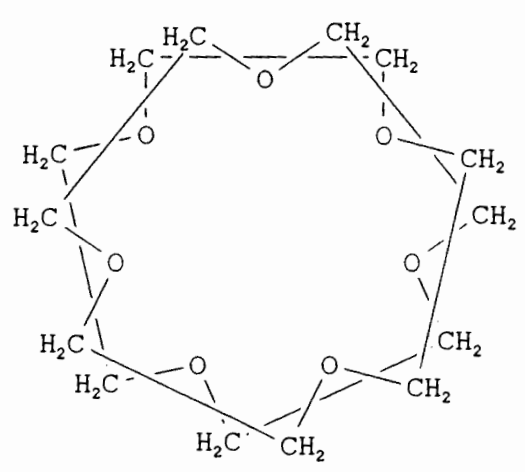

a)

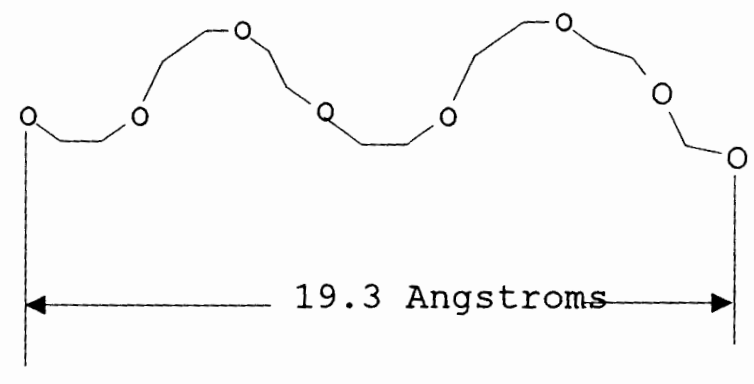

b)

Figure 5: Views a) Parallel and b) Normal to axis of helix

The cation is coordinated in a similar fashion as found for cations in crown ethers. Thus the view parallel to the axis of the helix is similar to the view of a crown ether when viewed normal to the plane containing the oxygens. The oxygens in a crown ether are all in the same plane, so any cation that is coordinated will be in that plane and equidistant to each oxygen. The oxygens in the PEO helix are spatially dislocated and so the cation is not equally coordinated to each oxygen because it is closer to some than to others. Because of this the cation can move relative to the helix if a potential is applied parallel to the axis of the helix. PEO can form complexes with many salts containing $\mathrm{Li}^{+}, \mathrm{Na}^{+}, \mathrm{K}^{+}, \mathrm{Cs}^{+}, \mathrm{Rb}^{+}, \mathrm{NH}_{4}^{+}$, $\mathrm{Mg}^{+2}, \mathrm{Ca}^{+2}, \mathrm{Zn}^{+2}, \mathrm{Cu}^{+2}$, and anions $\mathrm{F}^{-}, \mathrm{Cl}^{-}, \mathrm{Br}^{-}, \mathrm{I}^{-}, \mathrm{NO}_{3}^{-}$, 
$\mathrm{SCN}^{-}, \mathrm{ClO}_{4}^{-}, \mathrm{CF}_{3} \mathrm{SO}_{3}^{-}, \mathrm{BPh}_{4}^{-}$. The stoichiometry of the complex varies with the size of the cation. ${ }^{32}$ The PEO/salt complexes have a higher melting temperature than pure PEO and also the glass transition temperature is lowered, thus the amorphous phase is increased, this is referred to as solid solution in these polymers. The conductivities occurs only in the amorphous phase of the complex, thus crystallinity in a polymer salt complex is undesired.

Most research has focused on the formation of $\mathrm{PEO} / \mathrm{salt}$ complexes because $\mathrm{PEO}$ is readily available in pure form, and making new complexes in any laboratory is relatively easy. This research will focus on developing new anionic pendant groups attached to the polymer backbone or salts which will decrease the crystallinity and increase the amorphous phase in the polymers. Which will include an investigation of the syntheses of new salts that contain strong electron withdrawing groups; the chemistry of these salts will be investigated, as will their use in ionic salt complexes with PEO. The goal is to produce a salt which increases the conductivities of PEO. 


\section{Chemistry of $\left(\mathrm{CF}_{3} \mathrm{SO}_{2}\right)_{2} \mathrm{CH}_{2}$}

Chapter 3

FLUOROCARBON ACIDS

Fluorocarbon acids possess unusual properties that have generated widespread use and interest; for example perfluorinated acids have high acidities. The bulk of the research investigating these acids has been in the area of organometallic chemistry, the formation and structure of metal center complexes. One of the more interesting fluorinated acids is bis(trifluoromethylsulfonyl)methane, $\left(\mathrm{CF}_{3} \mathrm{SO}_{2}\right)_{2} \mathrm{CH}_{2}$. This acid is a nonhygroscopic, nonoxidizing protic acid that will react much as would any strong mineral or organic acid. It is one of the strongest carbon acids known, $\Delta G_{\text {acid }}=301.5 \mathrm{kcal} / \mathrm{mol}$ for $\left(\mathrm{CF}_{3} \mathrm{SO}_{2}\right)_{2} \mathrm{CH}_{2}$, $\Delta G_{\text {acid }}=299.5 \mathrm{kcal} / \mathrm{mol}$ for $\mathrm{CF}_{3} \mathrm{SO}_{3} \mathrm{H}$, gas phase acidities. ${ }^{33}$ These acids and their conjugate bases have a high thermodynamic stability with regard to the cleavage of the $\mathrm{CF}_{3}-\mathrm{S}, \mathrm{S}-\mathrm{O}$, and $\mathrm{C}-\mathrm{F}$ bonds. 34 
The preparation of fluoroalkysulfonyl methane derivatives will be discussed in this chapter. Methods of synthesis of salts and organic derivatives will be addressed and as will their possible introduction into known systems.

$$
\text { SYNTHESIS OF }\left(\mathrm{CF}_{3} \mathrm{SO}_{2}\right)_{2} \mathrm{CH}_{2}
$$

The acid is readily made by the reaction of trifluoromethylsulfonyl fluoride with two to four equivalents of methylmagnesium halide in ether (equations $7,8$ and 9 when $\mathrm{R}=\mathrm{H}), 35$

$\mathrm{R}_{\mathrm{f}} \mathrm{SO}_{2} \mathrm{~F} \quad \stackrel{\mathrm{RCH}_{2} \mathrm{MgX}}{\text { ether }} \rightarrow \mathrm{R}_{\mathrm{f}} \mathrm{SO}_{2} \mathrm{CH}_{2} \mathrm{R}$

$\mathrm{R}_{\mathrm{f}} \mathrm{SO}_{2} \mathrm{CH}_{2} \mathrm{R} \underset{\text { ether }}{\stackrel{\mathrm{RCH}_{2} \mathrm{MgX}}{\longrightarrow}} \mathrm{R}_{\mathrm{f}} \mathrm{SO}_{2} \mathrm{CHRMgX}+\mathrm{RCH}_{3}$

$\mathrm{R}_{\mathrm{f}} \mathrm{SO}_{2} \mathrm{CHRMgX} \underset{\text { ether }}{\stackrel{\mathrm{RCH}_{2} \mathrm{MgX}}{\rightarrow}} \mathrm{R}_{\mathrm{f}} \mathrm{SO}_{2} \mathrm{CHRSO}_{2} \mathrm{R}_{\mathrm{F}}+\mathrm{MgFX}$

$\mathrm{R}_{\mathrm{f}}=\mathrm{C}_{\mathrm{n}} \mathrm{F}_{2 \mathrm{n}+1} \mathrm{SO}_{2} \mathrm{~F}$

Ether $=\mathrm{THF}$, Diethyl ether

The yield from this net reaction varies depending on the solvent that is used. If THE is the solvent, yields of $75 \%$ can be achieved when $\mathrm{R}_{\mathrm{f}}=C \mathrm{CF}_{3}$; if diethyl ether is the solvent then the yield drops to $34 \%$ when $R_{f}=C_{3}$. 
Trifluoromethylsulfonylfluoride is produced by electrochemical fluorination of methanesulfonyl fluoride. Compounds of the general formula $\left(\mathrm{R}_{\mathrm{f}} \mathrm{SO}_{2}\right)_{2} \mathrm{CH}_{2}$ have been made, where $R_{f}=C F_{3}$ through $C_{20} F_{41} \cdot 36,37$

Neutral salts can be made by titrating with a base. ${ }^{38}$ Salts have been made with the general formula:

$$
\begin{aligned}
& {\left[\left(\mathrm{R}_{\mathrm{f}} \mathrm{SO}_{2}\right){ }_{2} \mathrm{CZ}\right]^{-}\left(1 /{ }_{\mathrm{n}} \mathrm{M}\right)+\mathrm{n}}
\end{aligned}
$$

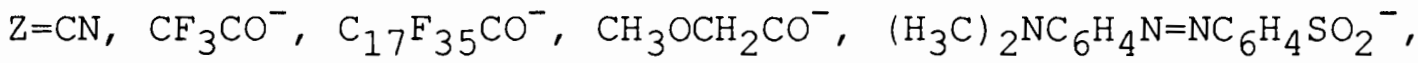

$$
\begin{aligned}
& \text { [ }\left(\mathrm{CH}_{3}\right)_{2}{ }_{2}{ }^{\mathrm{N}}{ }_{2} \mathrm{PO}^{-} \text {, ethylenebis (oxyethylenenitrilo) } \\
& \text { tetraacetic acid }
\end{aligned}
$$

$M=$ metal of valence $n$ or cationic organic group capable of stabilizing the anion. Due to the strong acidity of this compound it will react with sulfates that are used as drying agents, producing the corresponding metal salt. Thus care must be taken when drying derivatives of it. The ethylenebis(oxyethylenenitrilo) tetraacetic acid complex has a very interesting structure (Figure 6); all of the carboxylic hydroxyls are replaced by bis(trifluoromethylsulfonyl)methane groups. 


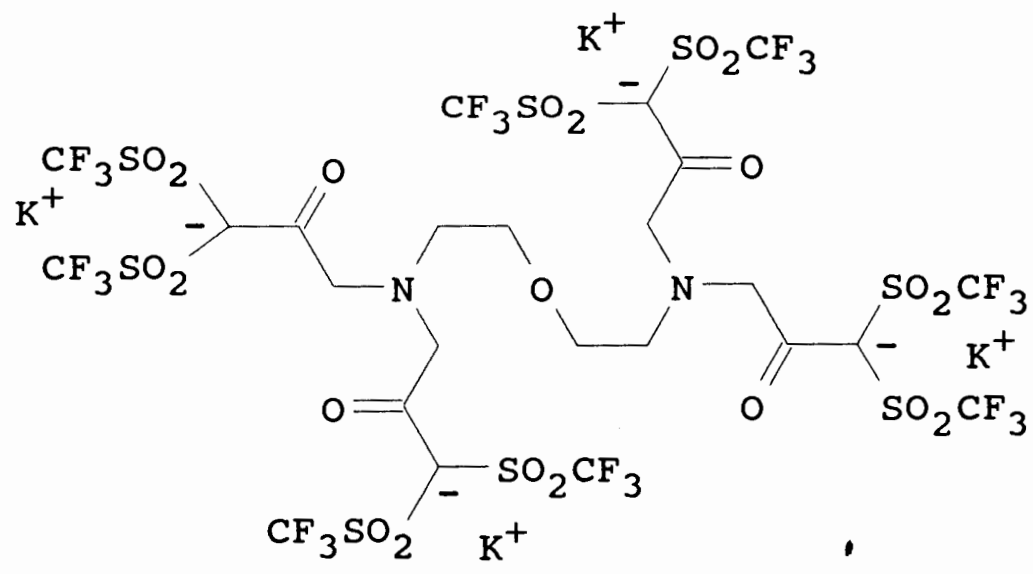

Figure 6: Structure of ethylenebis (oxyethylenenitrilo) tetraacetic acid

These molecules have been found to be useful as electrochemical devices for controlling light transmission or reflection and as the dielectric in capacitors. ${ }^{39}$

The tris analogue $\left(\mathrm{CF}_{3} \mathrm{SO}_{2}\right)_{3} \mathrm{CH}$ has been synthesized. It is a slightly stronger acid $\left(\Delta \mathrm{G}_{\mathrm{acid}}=289.0 \mathrm{kcal} / \mathrm{mole}\right.$, gas phase acicity ${ }^{33}$ ) than $\left(\mathrm{CF}_{3} \mathrm{SO}_{2}\right)_{2} \mathrm{CH}_{2}$ and has a very similar chemistry.

$\left(\mathrm{CF}_{3} \mathrm{SO}_{2}\right)_{2} \mathrm{CH}_{2}$ is soluble in protic solvents as well as aprotic solvents; studies of its acidity and reactivity can therfore be carried out with no solvent interference. 40 The reaction of $\left(\mathrm{CF}_{3} \mathrm{SO}_{2}\right)_{2} \mathrm{CH}_{2}$ with some transition metal complexes follows the following scheme:

$\left(\mathrm{Ph}_{3} \mathrm{P}\right)_{2} \mathrm{M}\left(\mathrm{C}_{2} \mathrm{H}_{4}\right)+\left(\mathrm{CF}_{3} \mathrm{SO}_{2}\right)_{2} \mathrm{CH}_{2} \rightarrow$ trans- $\left(\mathrm{Ph}_{3} \mathrm{P}\right)_{2} \mathrm{MH}\left[\mathrm{HC}\left(\mathrm{SO}_{2} \mathrm{CF}_{3}\right)_{2}\right]$ $\mathrm{M}=\mathrm{Pt}$ ， $\mathrm{Co}, \mathrm{Rh}$, Ir

$$
+\mathrm{H}_{2} \mathrm{C}=\mathrm{CH}_{2}
$$


The reaction in equation 10 produces a metal-carbon bond which is very labile and can be titrated with such weak bases as tetrahydrofuran (THF) generating the anion $\left(\mathrm{CF}_{3} \mathrm{SO}_{2}\right)_{2} \mathrm{CH}^{-}$and a cation which has a metal hydrogen (hydride) bond which is not acidic. ${ }^{41}$ Reactions of this type when carried out with $\left(\mathrm{R}_{\mathrm{f}} \mathrm{SO}_{2}\right)_{2} \mathrm{CH}_{2}$ (with $\mathrm{R}_{\mathrm{f}}=$ long-chain perfluoroalkyl groups) yield salts that have a high solubility in aromatic hydrocarbons. All other metal complexes (ie. Ti, K, Zr, Hf) that have been studied have resulted in metal complexes in which the cations have had a strong interaction with the sulfonyl oxygens rather than the methanide carbon. ${ }^{41,42}$

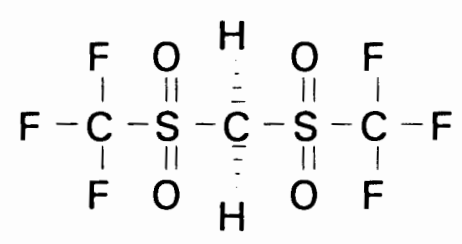

a)

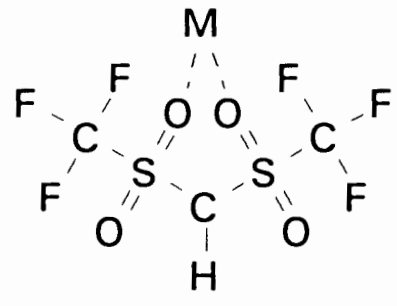

b)<smiles>[M]C(C([M])S(=O)(=O)C(F)(F)F)S(=O)(=O)C(F)(F)F</smiles>

c)

Figure 7: Structure of a) $\left(\mathrm{CF}_{3} \mathrm{SO}_{2}\right)_{2} \mathrm{CH}_{2}$ and b) $\left(\mathrm{CF}_{3} \mathrm{SO}_{2}\right){ }_{2} \mathrm{CH}^{-}$ coordinated to $\mathrm{SO}_{2}$ oxygens and $\left.\mathrm{C}\right)\left(\mathrm{CF}_{3} \mathrm{SO}_{2}\right)_{2} \mathrm{CH}^{-}$ with a $\mathrm{M}-\mathrm{C}$ bond

The position at which the metal coordinates affects the infrared absorption frequency of adjacent bonds; 
Compound $\mathrm{CH}$ stretch

$$
\mathrm{SO}_{2} \text { Sym }
$$$$
\mathrm{SO}_{2} \text { asym }
$$
a) $\left(\mathrm{CF}_{3} \mathrm{SO}_{2}\right){ }_{2} \mathrm{CH}_{2}$

$2991,2926 \mathrm{~cm}^{-1}$

$1113 \mathrm{~cm}^{-1}$

$1400-1360 \mathrm{~cm}^{-1}$

b) $\left(\mathrm{CF}_{3} \mathrm{SO}_{2}\right){ }_{2} \mathrm{CHK}$

$3084 \mathrm{~cm}^{-1}$

$1133,1092 \mathrm{~cm}^{-1}$

$1328,1302 \mathrm{~cm}^{-1}$

C) $\left(\mathrm{CF}_{3} \mathrm{SO}_{2}\right)_{2} \mathrm{CHAg}$

$2993 \mathrm{~cm}^{-1}$

$1120 \mathrm{~cm}^{-1}$

$1340 \mathrm{~cm}^{-1}$

When the cation is coordinated with the central carbon (example c) the wavenumbers of the $\mathrm{C}-\mathrm{H}$ and $\mathrm{SO}_{2}$ stretches are not affected in a significant manner. However the wavenumbers of the $\mathrm{C}-\mathrm{H}$ and $\mathrm{SO}_{2}$ stretches are greatly affected when the cation is coordinated to the sulfonyl oxygens (example b), both a shift of their absorbance and a splitting is observed.

The coordination of the cation to the sulfonyl oxygens results in a lamellar crystal structure with the cation coordinated to six adjacent sulfonyl oxygens between layers. This was demonstrated by D.D. DesMarteau when he and his research group studied the crystal structures of $\mathrm{K}\left[\mathrm{CH}\left(\mathrm{SO}_{2} \mathrm{CF}_{3}\right)_{2}\right]$ and $\mathrm{K}\left[\mathrm{CH}\left(\mathrm{SO}_{2} \mathrm{~F}\right)_{2}\right]$. They found that the cation is coordinated to the oxygens rather than the central carbon. ${ }^{43}$ 
The Synthesis of New Fluoroalkylsulfonyl Methanide Derivatives

Many neutral salts have been made with $\mathrm{CH}\left(\mathrm{SO}_{2} \mathrm{CF}_{3}\right)_{3}$ and their structures show that the central carbon and sulfur atoms exist in a plane (SCS bond angle is approximately $120^{\circ}$ ) and the $\mathrm{CF}_{3}$ groups are oriented so that two of them are above and the other is below the $\mathrm{CS}_{3}$ plane. The cation in the potassium salt is coordinated to six sulfonyl oxygens and to a seventh oxygen if the salt is the monohydrate. 44

Few of the salts of the unique acid bis(trifluoromethylsulfonyl) methane, $\left(\mathrm{CF}_{3} \mathrm{SO}_{2}\right)_{2} \mathrm{CH}_{2}$, have been characterized or investigated for their utility in organic synthesis. Studies of the structures of the potassium salts and transition metal complexes have been carried out by different groups around the world. Little of this work has focused on the ability to incorporate the functionality of this molecule into organic compounds. Recently, work has been done to incorporate this functionality into a perfluorinated system: ${ }^{45}$ 


$$
\begin{aligned}
& \left(\mathrm{CF}_{3} \mathrm{SO}_{2}\right)_{2} \mathrm{CH}_{2}+\mathrm{K}_{2} \mathrm{CO}_{3} \longrightarrow\left(\mathrm{CF}_{3} \mathrm{SO}_{2}\right)_{2} \mathrm{CH}^{-} \mathrm{K}^{+}+\mathrm{KHCO}_{3} \\
& \left(\mathrm{CF}_{3} \mathrm{SO}_{2}\right)_{2} \mathrm{CH}^{-} \mathrm{K}^{+}+\mathrm{CH}_{3} \mathrm{MgCl} \longrightarrow\left(\mathrm{CF}_{3} \mathrm{SO}_{2}\right)_{2} \mathrm{CMgCl}^{-} \mathrm{K}^{+}+\mathrm{CH}_{4}
\end{aligned}
$$

$$
\left(\mathrm{CF}_{3} \mathrm{SO}_{2}\right)_{2} \mathrm{CMgCl}^{-\mathrm{K}^{+}}+\mathrm{F}_{2} \mathrm{C}=\mathrm{CFCF}_{2} \mathrm{I} \longrightarrow\left[\left(\mathrm{CF}_{3} \mathrm{SO}_{2}\right)_{2} \mathrm{CCF}=\mathrm{CFCF}_{3}\right]^{-} \mathrm{K}^{+}
$$

The addition product to the hydrocarbon analogue has already been made: ${ }^{37}$

$$
\left(\mathrm{CF}_{3} \mathrm{SO}_{2}\right)_{2} \mathrm{CHK}+\mathrm{H}_{2} \mathrm{C}=\mathrm{CHCH}_{2} \mathrm{Br} \rightarrow\left(\mathrm{CF}_{3} \mathrm{SO}_{2}\right)_{2} \mathrm{CHCH}_{2} \mathrm{CH}=\mathrm{CH}_{2}+\mathrm{KBr}
$$

The strength of $\left(\mathrm{CF}_{3} \mathrm{SO}_{2}\right)_{2} \mathrm{CKH}$ as a nucleophile is rather weak because of the strong electron withdrawing $\mathrm{CF}_{3} \mathrm{SO}_{2}$ groups, but it is thought that the strength of the dianion $\left(\mathrm{CF}_{3} \mathrm{SO}_{2}\right)_{2} \mathrm{CKMgCl}$ is much greater as a nucleophile. This is demonstrated in the above example (Equation 13) when substitution of the dianion by perfluoroallyl iodide occurs. The rearrangement in the fluorocarbon addition (Equation 13) provides a route to an internal double bond. 45

$\left(\mathrm{CE}_{3} \mathrm{SO}_{2}\right)_{2} \mathrm{CH}_{2}$ will form carbenes that react with alkenes, halogens, alcohols, benzene, and other organics. This is useful for introducing the bis(trifluoromethylsulfonyl) functionality into organic molecules. 46 
$\left(\mathrm{CF}_{3} \mathrm{SO}_{2}\right)_{2} \mathrm{CH}_{2}+\mathrm{PhI}(\mathrm{OAC})_{2} \longrightarrow \mathrm{PhI}^{+-} \mathrm{C}\left(\mathrm{SO}_{2} \mathrm{CF}_{3}\right)_{2}+2 \mathrm{ACOH}$

This structure has been best described as an ylid, since some double bond character has been reported for the C-I bond. 47 Additions to aromatic compounds, cyclic alkenes and reactions with noncharged nucleophiles, and halogens have also been reported in good yields.

Condensation reactions of $\left(\mathrm{CF}_{3} \mathrm{SO}_{2}\right)_{2} \mathrm{CH}_{2}$ have been carried out with aromatic aldehydes to form 1-aryl-2,2bis(trifluoromethylsulfonyl) ethylene. This double bond is very activated because of its proximity to the highly electron withdrawing $\mathrm{CF}_{3} \mathrm{SO}_{2}$ groups.

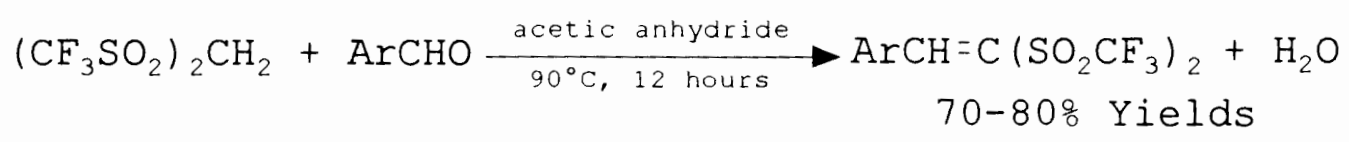

An anion can be easily formed because of the polarity of this bond and salts made from this anion with anhydrous pyridine are thermally stable and nonhygroscopic. Addition reactions to the double bond will also occur with other atoms, such as phosphites. ${ }^{48}$ 


\section{INDUSTRIAI APPLICATIONS}

One industrial application of $\left(\mathrm{CF}_{3} \mathrm{SO}_{2}\right)_{2} \mathrm{CH}_{2}$ has been patented. Bis(perfluoroalkylsulfonyl)methanes are very efficient catalysts for the polymerization of epoxy resins. They are useful for polymerizing resins at ambient temperatures or low heat in a relatively short period of time. ${ }^{49}$ Equations 17 and 18 illustrate two polymerization reactions that $\left(\mathrm{CF}_{3} \mathrm{SO}_{2}\right)_{2} \mathrm{CH}_{2}$ will catalyze, a hydrocarbon epoxy resin, Equation 17, and a epoxy terminated silane, Equation 18.
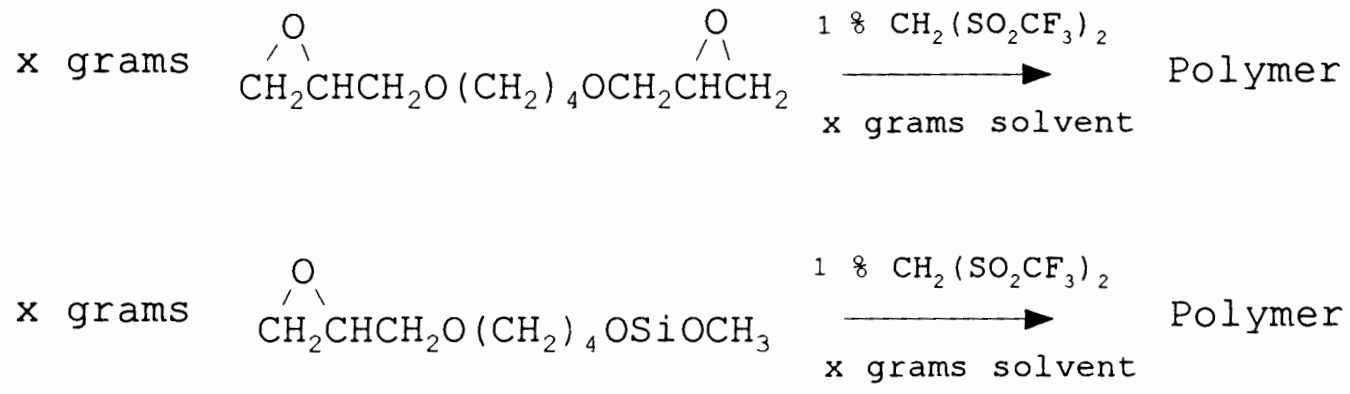

Most epoxy applications require that polymerization occur in situ; this means that the catalysis must be able to be controlled so that polymerization does not begin prior to application of the coating. Solvents which will latentize, or retard the catalytic effect of bis(perfluoroalkylsulfonyl) methanes have been investigated. For example, a latentized (3:1 - 1:1 
wt./epoxy to solvent), catalyzed solution (1:100 wt./wt. catalyst to resin) gelled after 24 hours, and thin films cured to a tack-free state after only 10 minutes. The solvents which gave the greatest delay to gelation of the bulk solutions were ethers, esters, and aromatic solvents, including the following: ethyl acetate, benzene, ethyl ether, isopentyl acetate, toluene, and furan. This delay in polymerization can be controlled byusing a specific amount of catalyst and solvent. The rate of solvent removal(evaporation) determines the time to a tack free film.

Because the $\mathrm{CF}_{3} \mathrm{SO}_{2}$ group is extremely electronwithdrawing, the lithium salt of this acid should make an excellent choice for a use as an electrolyte in a polymer system. The effect of the $\mathrm{CF}_{3} \mathrm{SO}_{2}$ groups on the chemistry of the compound is well worth investigating. The chemistry of the acid has already been seen to be diverse, and should yield some interesting products. The use of the lithium salts for use as battery electrolytes has been investigated in other analogous compounds; $\left(\mathrm{CF}_{3} \mathrm{SO}_{2}\right)_{3} \mathrm{CLi}$, and $\left(\mathrm{CF}_{3} \mathrm{SO}_{2}\right)_{2} \mathrm{NLi}$. The salt $\left(\mathrm{CF}_{3} \mathrm{SO}_{2}\right)_{2} \mathrm{CHLi}$ also has potential as an electrolyte. 


\section{Chapter 4 \\ Experimental Methods}

\section{Vacuum Inines}

A glass vacuum system was used for transferring volatile materials except for fluorine gas, for which a metal system was utilized. The glass system consisted of a glass manifold made from $22 \mathrm{~mm}$ inside-diameter Pyrex tubing, fitted with four Kontes high vacuum stopcocks with glass $10 / 30$ female joints. The manifold was connected to a Welch Duo-Seal rotary vacuum pump through a liquid nitrogen cooled trap. Pressures in the manifold were monitored with a Frederick Company Televac thermocouple gauge or a mercury manometer. The Televac gauge was used to monitor pressures less than $100 \mu \mathrm{m} \mathrm{Hg}$, and the mercury manometer was used to monitor pressures greater than $10 \mathrm{~mm}$ Hg. All permanent joints were sealed with Glyptol Enamel. Fluorolube GR-290 grease was used to lubricate and seal all taper joints and stopcocks. Ball joints were sealed with Apiezon-N grease or with Halocarbon wax.

A metal vacuum Iine was used to transfer anhydrous fluorine gas. It was constructed of 0.125 inch insidediameter copper tubing fitted with four whitey stainless Steel valves with $10 / 30$ standard taper copper joints. All permanent fittings were attached with silver solder. The 
Iine was attached to a vacuum pump in the same manner as the glass line. An ACCD Helicoid Gage vacuum gauge was used to monitor pressures down to $1 \mathrm{~mm} \mathrm{Hg}$. Reaction Vessels

Reactions performed at low pressures and temperatures were carried out in $75 \mathrm{ml}$ Pyrex glass vessels which were equipped with Teflon coated magnetic stir bars, a Kontes high vacuum stopcock, and a male $10 / 30$ tapered glass joint.

Reactions carried out at higher temperatures or pressures, or where the reactants would damage the glass, were carried out in $75 \mathrm{ml}$ stainless steel vessels. They were equipped with whitey stainless steel valves and tapered brass $10 / 30$ joints.

\section{INSTRUMENTATION AND METHODS}

Infrared spectroscopy

Infrared spectra were collected using a Perkin-Elmer model 2000 FTIR spectrophotometer using $\mathrm{KBr}$ or NaCl plates for liquids and solids. Gas spectra were collected using a $10 \mathrm{~cm}$ path length Pyrex glass gas cell fitted with a Kontes high vacuum stopcock and KBr windows. NMR Spectroscopy

${ }^{1} \mathrm{H}$ and ${ }^{19} \mathrm{~F}$ NMR spectra were recorded using a Varian Model EM-390 spectrometer, operating at $90 \mathrm{MHz}$ for proton 
and $84.67 \mathrm{MHz}$ for fluorine resonances. ${ }^{1} \mathrm{H}$ spectra were also collected on a Bruker AMX400 spectrometer operating at $400 \mathrm{MHz}$ for the proton resonances. TMS was used as a ${ }^{1} \mathrm{H}$ reference source and $\mathrm{CFCl}_{3}$ was used as an internal standard for ${ }^{19} \mathrm{~F}$ NMR; the resonance of the standards was set to zero ppm. All chemical shifts are reported as $\delta$ (ppm), negative chemical shifts refer to upfield shifts in the resonances from TMS or $\mathrm{CFCl}_{3}$, while positive shifts refer to resonances downfield from the references. Mass spectra

Mass spectra were obtained using a FISONS VG-QuattroSQ combined with Fast Atom Bombardment (FAB) at the Instrumental Laboratory at Colorado State University. Elemental Analysis

Analysis of all new compounds were carried out by Beller Mikroanalytisches Laboratorium, Gottingen, Germany. Melting Points

All melting/decomposition points of solid samples were determined using either sealed or open capillary tubes in a Mel-Temp apparatus. All reported temperatures are uncorrected.

Sublimations

Conventional Pyrex glass sublimation units were employed for purification of solid samples. All were done using tap water as the coolant. 


\section{Dry Box}

All air sensitive compounds were handled under an atmosphere of dry nitrogen in a Kewaunee Scientific Equipment dry box. The atmosphere inside the dry box was continuously circulated over molecular sieve.

\section{Reagents}

Allyl Bromide, $\mathrm{CH}_{2}=\mathrm{CHCH}_{2} \mathrm{Br}$ was obtained from $\mathrm{MCB}$ and was used without further purification.

$\mathrm{Bis}\left(\right.$ trifluoromethylsulfonyl) methane, $\left(\mathrm{CF}_{3} \mathrm{SO}_{2}\right)_{2} \mathrm{CH}_{2}$ which was prepared by treatment of $\mathrm{CF}_{3} \mathrm{SO}_{2} \mathrm{~F}$ with $\mathrm{CH}_{3} \mathrm{MgCl}$, was a gift from Dr. Fred Behr at the 3M Company. ${ }^{50}$

Carbonates, $\mathrm{Li}_{2} \mathrm{CO}_{3}, \mathrm{~K}_{2} \mathrm{CO}_{3}, \mathrm{La}_{2}\left(\mathrm{CO}_{3}\right)_{3}, \mathrm{ZnCO}_{3}$ were obtained from Mallinkrodt Co, and used without further purification. $\mathrm{Ag}_{2} \mathrm{CO}_{3}$ was synthesized from $\mathrm{AgNO}_{3}$ and $\mathrm{NaHCO}_{3}$ in the laboratory according to literature method. ${ }^{51}$

Diethyl Ether, anhydrous, $\left(\mathrm{CH}_{3} \mathrm{CH}_{2}\right)_{2} \mathrm{O}$ was obtained from J.T. Baker Co. and was used without further purification. Diglyme, $\left(\mathrm{CH}_{3} \mathrm{OCH}_{2} \mathrm{CH}_{2}\right)_{2} \mathrm{O}$ was obtained from J.T. Baker Co. and was distilled and stored over 4A molecular sieve. Epibromohydrin, $\mathrm{OCH}_{2} \mathrm{CHCH}_{2} \mathrm{Br}$ was obtained from Aldrich Chemical Co. and was used without further purification.

Ethanol, absolute, $\mathrm{CH}_{3} \mathrm{CH}_{2} \mathrm{OH}$ was obtained from Grain Distiller Inc. and was used without further purification. 
Ethyl magnesium chloride, $\mathrm{CH}_{3} \mathrm{CH}_{2} \mathrm{MgCl}$ was obtained from Aldrich Chemical Co. and was used without further purification.

Lithium hydroxide, LiOH was obtained from Aldrich Chemical Co. and was used without further purification. Methanol, absolute, $\mathrm{CH}_{3} \mathrm{OH}$ was obtained from J.T. Baker Co. and was purified according to literature methods and stored over $4 \mathrm{~A}$ molecular sieve.

Methyl magnesium chloride, $\mathrm{CH}_{3} \mathrm{MgCl}$ was obtained from Mallinkrodt Co. and was used without further purification. n-Propyl iodide, $\mathrm{CH}_{3} \mathrm{CH}_{2} \mathrm{CH}_{2} \mathrm{I}$ was obtained from Aldrich Chemical Co. and was used without further purification. Silver fluoride, AgF was synthesized in the laboratory according to literature methods. 51 Also AgF was obtained from Alf Atochem and was used without further purification.

Sulfur trioxide, $\mathrm{SO}_{3}$, was distilled from $130 \%$ oleum obtained from DuPont Company.

Tetrafluoroethylene, inhibited, $C F_{2}=C F_{2}$, was obtained from PCR and was used without further purification. 
Chapter 5

TRIFLUOROMETHYLSULFONYL SYSTEMS

A number of salts containing the $\mathrm{CF}_{3} \mathrm{SO}_{2}$ group were prepared and characterized by several different methods. Compounds that contain the $\mathrm{CF}_{3} \mathrm{SO}_{2}$ group are of interest because of their electron-withdrawing ability and their usefulness as possible lithium battery electrolytes.

\section{General synthesis Routes}

salts

The general procedure for the preparation of salts of bis(trifluoromethylsulfonyl)methane involves neutralization of the acid with the appropriate carbonate salt in either methanol or ethanol, e.g. $\mathrm{K}_{2} \mathrm{CO}_{3}$ gives the potassium salt, followed by filtration, evaporation of the solvent and drying at $100^{\circ} \mathrm{C}$ under vacuum. 37 In this study the salts, $\left(\mathrm{CF}_{3} \mathrm{SO}_{2}\right)_{2} \mathrm{CHK},\left(\mathrm{CF}_{3} \mathrm{SO}_{2}\right){ }_{2} \mathrm{CHLi},\left[\left(\mathrm{CF}_{3} \mathrm{SO}_{2}\right)_{2} \mathrm{CH}\right]_{3} \mathrm{La}$, and $\left[\left(\mathrm{CF}_{3} \mathrm{SO}_{2}\right)_{2} \mathrm{CH}\right]_{2} \mathrm{Zn}$, were prepared in this manner. Of these salts $\left(\mathrm{CF}_{3} \mathrm{SO}_{2}\right)_{2} \mathrm{CHLi}_{1}\left[\left(\mathrm{CF}_{3} \mathrm{SO}_{2}\right)_{2} \mathrm{CH}\right]_{3} \mathrm{La}$ and $\left[\left(\mathrm{CF}_{3} \mathrm{SO}_{2}\right)_{2} \mathrm{CH}\right]_{2} \mathrm{Zn}$ were new. This method is generally used with alkali and alkaline earth metal carbonate salts; however this study showed that 
bis(trifluoromethylsulfonyl)methane is acidic enough to react directly with metal oxides:

$2\left(\mathrm{CF}_{3} \mathrm{SO}_{2}\right)_{2} \mathrm{CH}_{2}+\mathrm{MO} \longrightarrow\left[\left(\mathrm{CF}_{3} \mathrm{SO}_{2}\right)_{2} \mathrm{CH}\right]_{2} \mathrm{M}+\mathrm{H}_{2} \mathrm{O}$ (19) $\mathrm{M}=\mathrm{Ca}, \mathrm{Hg}$

This reaction will occur neat, however the rate is greatly increased by the use of a solvent, eg., methanol or water. The calcium and mercury salts prepared using this method are new compounds.

The reaction between the acid and a reducing agent was investigated. Good yields of the calcium salt were obtained when the acid was reacted with the hydride in organic solvents:

$$
\begin{aligned}
& \left(\mathrm{CF}_{3} \mathrm{SO}_{2}\right)_{2} \mathrm{CH}_{2}+\mathrm{CaH}_{2} \stackrel{\text { xylene }}{\longrightarrow}\left[\left(\mathrm{CF}_{3} \mathrm{SO}_{2}\right)_{2} \mathrm{CH}_{2}^{-2} \mathrm{Ca}^{2+}+2 \mathrm{H}_{2}(\mathrm{~g})\right. \\
& \mathrm{M}=\mathrm{Ca}, \mathrm{Hg}
\end{aligned}
$$

All of the hydride could be converted by using an excess of the acid. Thus, by removing the solvent a pure product could be obtained easily. The product is a white solid that is very hygroscopic. The two methods of preparing the calcium salts are equal with respect to the yields, however the purification of the calcium oxide product is easier and required a shorter reaction time.

Reactions with other hydrides were not attempted. An attempt to synthesize the dianion, $\left(\mathrm{CF}_{3} \mathrm{SO}_{2}\right)_{2} \mathrm{C}^{-2}$, was made 
using a strong base, butyllithium. The reaction mixture spontaneously detonated after ninety minutes. A white solid precipitate was observed in the reaction vessel before the explosion.

Organic salts of bis(trifluoromethylsulfonyl)methane have been made in the same manner, e.g. neutralization with an organic base. ${ }^{45}$ These were not investigated in this study because the intent was to investigate the feasibility of incorporating the bis/trifluoromethylsulfonyl) group into organic molecules.

\section{$\alpha$-Halogen Disulfones}

The chloro and bromo derivatives of the potassium salt of bis(trifluoromethylsulfonyl)methane are known, but have not been investigated fully. In this study $\left(\mathrm{CF}_{3} \mathrm{SO}_{2}\right)_{2} \mathrm{CHBr}, \quad\left(\mathrm{CF}_{3} \mathrm{SO}_{2}\right)_{2} \mathrm{CKBr}$ were prepared. Neither of these compounds were new, but new synthetic routes to these compounds were investigated. They are generally produced by the reaction of the salt with an equivalent amount of the halogen:

$$
\begin{array}{ll}
\left(\mathrm{CF}_{3} \mathrm{SO}_{2}\right)_{2} \mathrm{CHM} & +\mathrm{X}_{2} \stackrel{\mathrm{CCl}_{4}}{\longrightarrow}\left(\mathrm{CF}_{3} \mathrm{SO}_{2}\right) \mathrm{CHX}+\mathrm{MX} \\
\mathrm{M}=\mathrm{K}, \mathrm{Na} & \mathrm{X}=\mathrm{Cl}, \mathrm{Br}
\end{array}
$$

The halogenation is rapid at room temperature and does not require an excess of halogen. During the 
synthesis of $\left(\mathrm{CF}_{3} \mathrm{SO}_{2}\right)_{2} \mathrm{CHBr}$, an excess of bromine was added, followed by the addition of a small quantity of mercury. This resulted in a loss of approximately half of the anticipated product. Upon further investigation it was found that the $\alpha$-bromo compound reacts with elemental mercury giving $\left[\left(\mathrm{CF}_{3} \mathrm{SO}_{2}\right)_{2} \mathrm{CH}\right]_{2} \mathrm{Hg}$ and $\mathrm{HgBr}_{2}$.

The reaction of $\left(\mathrm{CF}_{3} \mathrm{SO}_{2}\right){ }_{2} \mathrm{CHBr}$ with magnesium was also investigated and it was found that the magnesium will react exothermically to give a yellow colored product. This reaction appeared to be quantitative, however the product was never isolated but was used in situ. This method may never replace the transmetallation reaction with a Grignard reagent, such as $\mathrm{CH}_{3} \mathrm{MgX}$, because of the loss in yield incurred in the production of the $\alpha$-bromo derivative. The reaction of $\left(\mathrm{CF}_{3} \mathrm{SO}_{2}\right)_{2} \mathrm{CHBr}$ with $\mathrm{Mg}$ would be useful if only a monosubstituted acid was desired, since the reaction of the acid with $\mathrm{CH}_{3} \mathrm{MgX}$ can result in both of the $\alpha$-hydrogens being replaced. The preparation of $\left(\mathrm{CF}_{3} \mathrm{SO}_{2}\right)_{2} \mathrm{CHMgBr}$ from $\left(\mathrm{CF}_{3} \mathrm{SO}_{2}\right)_{2} \mathrm{CHBr}$ was done on a small scale and the product was reacted with allyl bromide in an attempt to make an olefin that contains the $\mathrm{CH}\left(\mathrm{SO}_{2} \mathrm{CF}_{3}\right)_{2}$ functional group:

$\left(\mathrm{CF}_{3} \mathrm{SO}_{2}\right)_{2} \mathrm{CHMgBr}+\mathrm{CH}_{2}=\mathrm{CHCH}_{2} \mathrm{Br} \longrightarrow\left(\mathrm{CF}_{3} \mathrm{SO}_{2}\right)_{2} \mathrm{CHCH}_{2} \mathrm{CH}=\mathrm{CH}_{2}+\mathrm{MgBr}_{2}$ 
This reaction appeared to work giving the product in a 22\% yield. The NMR data supported the conclusion that an allyl group was added.

The reaction of the Grignard reagent with epibromohydrin was attempted. This synthesis resulted in a light brown liquid that distills at $128^{\circ} \mathrm{C}(15 \mathrm{~mm} \mathrm{Hg})$ in about a $20 \%$ yield.

$$
\begin{aligned}
& \left(\mathrm{CF}_{3} \mathrm{SO}_{2}\right)_{2} \mathrm{CH}_{2}+\mathrm{CH}_{3} \mathrm{MgCl} \longrightarrow\left(\mathrm{CF}_{3} \mathrm{SO}_{2}\right)_{2} \mathrm{CHMgCl}+\mathrm{CH}_{4} \text { (23) }
\end{aligned}
$$

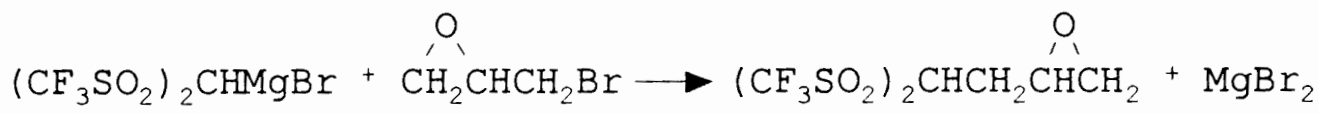

This product, if made, would allow the formation of polymers, diols, or halohydrins, and would be unstable at room temperature as a monomer; the acidity of the $\alpha$ hydrogen on the methine carbon is high enough to catalyze the polymerization of epoxy resins. This reaction sequence is supported by the fact that the proton NMR resonances seem to be similar to those found in the halohydrins made by $N$. Hamel. ${ }^{52}$ The proton NMR spectrum can be explained by the following assignments: two doublets of doublets at $4.11 \mathrm{ppm}$ and $4.19 \mathrm{ppm}$, a complex multiplet at $3.86 \mathrm{ppm}$, two additional doublets of doublets overlapping at $3.5 \mathrm{ppm}$, and the hydroxyl protons appearing at $5.6 \mathrm{ppm}$ and $6.3 \mathrm{ppm}$. The sample which was made in this 
research also has broad unresolved resonances at $1.5-2 \mathrm{ppm}$ and 3.5-4.0 ppm which indicate the possible presence of short chain telomers. Two doublets appearing at $1.0 \mathrm{ppm}$ and $1.3 \mathrm{ppm}$ along with two multiplets at $1.6 \mathrm{ppm}$ and 1.9 ppm help to reinforce the idea that the diol was present, but probably not stable, because of the formation of polymeric materials.

The ability of bases to open epoxide rings also throws doubt on the possibility of this product ever being formed. Grignard reagents typically are strong bases, and thus could cause a ring opening reaction that would produce an alcohol upon hydrolysis with water.

A different route to the epoxide derivative is to use the salt rather than the parent acid because this affords some protection to the epoxide ring. $\left(\mathrm{CF}_{3} \mathrm{SO}_{2}\right)_{2} \mathrm{CHK}+\mathrm{CH}_{3} \mathrm{MgCl} \longrightarrow\left(\mathrm{CF}_{3} \mathrm{SO}_{2}\right)_{2} \mathrm{CKMgCl}+\mathrm{CH}_{4}$

This reaction relies on the fact that the acid, $\left(\mathrm{CF}_{3} \mathrm{SO}_{2}\right)_{2} \mathrm{CH}_{2}$ is very strong, but its salt $\left(\mathrm{CF}_{3} \mathrm{SO}_{2}\right)_{2} \mathrm{CHK}$ is such a weak acid that it cannot be neutralized by $\mathrm{NaOH}$ (aq). Therefore $\left(\mathrm{CF}_{3} \mathrm{SO}_{2}\right)_{2} \mathrm{CKMgCl}$ should be a strong base. A reaction using this material would not spontaneously polymerize or undergo ring-opening reactions:

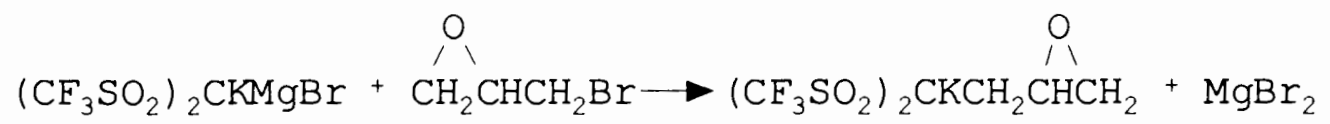


However, the Grignard reagent could again attack the epoxide ring preferentially over the bromine, causing formation of materials other than the desired product.

Characterization of the product of reaction (26) shows that the epoxide ring was initially present; this material would likely polymerize under acid conditions. Also under acid conditions the salt would be converted to the acid form. The lithium salt form of this epoxide is a good candidate for a lithium battery electrolyte.

A summary of the compounds prepared during this research has been summarized in Table 3. This is intended to show the new compounds that were synthesized and compounds that need further investigation. 


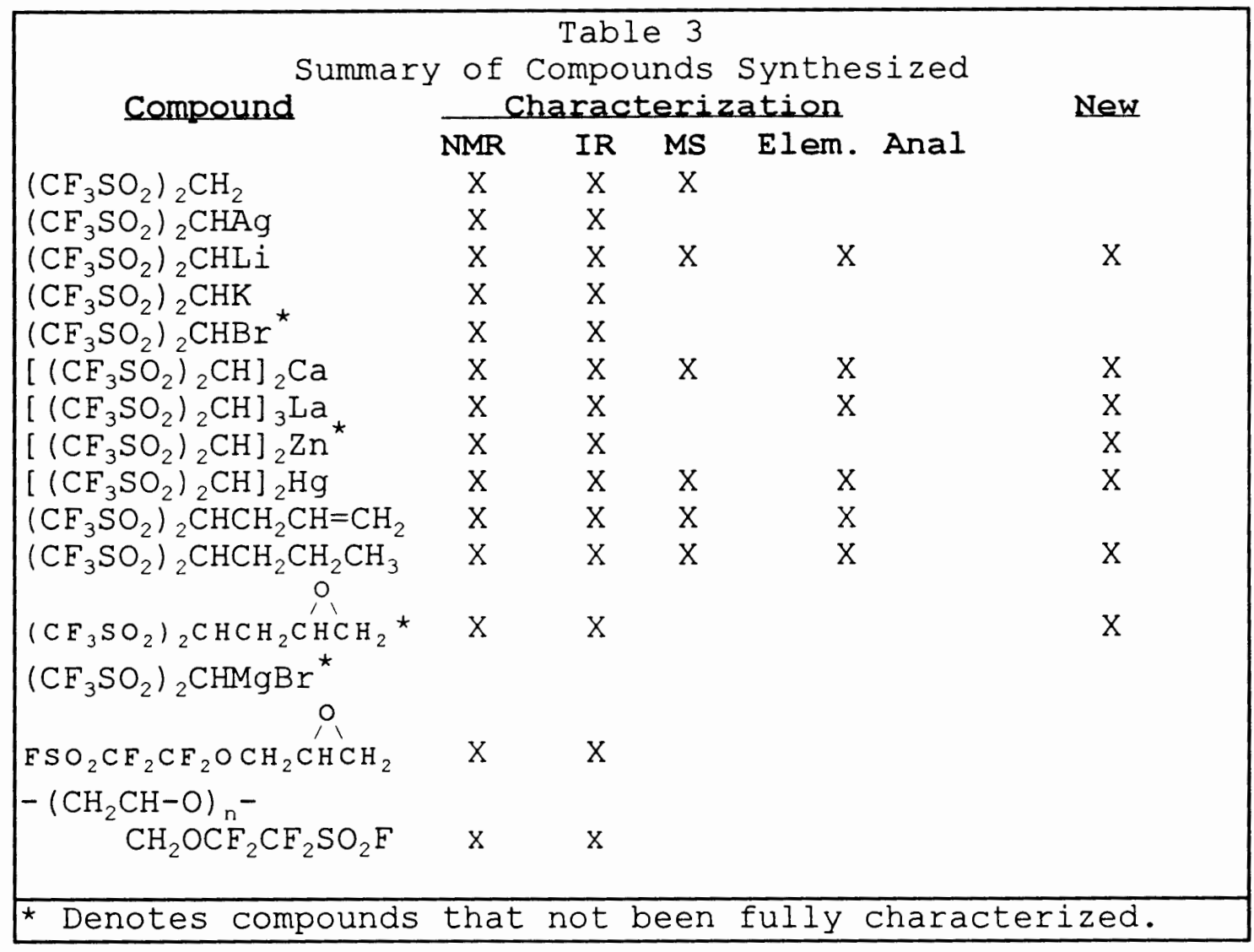




\section{Summary}

The research that was completed during this investigation shows that the salts and derivatives of bis(trifluoromerthylsulfonyl)methane are versatile. Three methods for the synthesis of the salts were used: reaction with carbonates, oxides, and hydrides. Of these methods the reaction with oxides and hydrides were new, and resulted in a significant increase in the product yield and an improvement in the recovery of the product from the reaction mixture. Also the variety of products which may be synthesized has been increased.

The versatility of the mercury salt as an organic precursor has been shown by utilizing it in a variety of synthesis: $\left(\mathrm{CF}_{3} \mathrm{SO}_{2}\right)_{2} \mathrm{CHCH}_{2} \mathrm{CH}=\mathrm{CH}_{2}, \quad\left(\mathrm{CF}_{3} \mathrm{SO}_{2}\right)_{2} \mathrm{CHCH}_{2} \mathrm{CH}_{2} \mathrm{CH}_{3}$, 公 $\left(\mathrm{CF}_{3} \mathrm{SO}_{2}\right)_{2} \mathrm{CHBr}$ and $\left(\mathrm{CF}_{3} \mathrm{SO}_{2}\right)_{2} \mathrm{CHCH}_{2} \mathrm{CHCH}_{2}$. The ease of synthesis and the diverse chemistry of the mercury salt make this a valuable precursor when trying to introduce the $\left(\mathrm{CF}_{3} \mathrm{SO}_{2}\right)_{2} \mathrm{CH}$ functionality into an organic compound.

The use of Grignard reagents for incorporating the $\left(\mathrm{CF}_{3} \mathrm{SO}_{2}\right)_{2} \mathrm{CH}$ group into organic compounds is already known. However the new technique to make the Grignard reagent, that was investigated in this research, has increased the ease by which the Grignard is produced for use in organic synthesis. By using the Grignard reagent, intermediate purification steps can be eliminated and many synthesis 
may be done using a "one-pot" technique. In the synthesis of the epoxide derivative the the use of a Grignard reagent causes a ring-opening reaction to occur, producing a halohydrin. This halohydrin product could be used in further synthetic steps, since halohydrins are used extensively in polymer chemistry to produce polyurethanes, epoxy resins, and polyglycols.

The lithium salt of $\left(\mathrm{CF}_{3} \mathrm{SO}_{2}\right){ }_{2} \mathrm{CH}_{2}$ and the lithium 金 polymer salt of $\mathrm{FSO}_{2} \mathrm{CF}_{2} \mathrm{CF}_{2} \mathrm{OCH}_{2} \mathrm{CHCH}_{2}$ are currently undergoing conductivity studies at oregon state University. 


\section{Infrared spectra}

The infrared spectra for these salts and derivatives of bis(trifluoromethylsulfonyl)methane are presented in the Appendix and summarized in Table 4.

The $\mathrm{SO}_{2}, \mathrm{CF}_{3}$, and $\mathrm{CH}$ have distinctive absorbances in the infrared region. All of the compounds discussed thus far have shown strong absorbances for the $\mathrm{SO}_{2}$ group, both asymmetric and symmetric stretching modes, $1340-1310 \mathrm{~cm}^{-1}$ and 1120-1100 $\mathrm{cm}^{-1}$ respectively. These values are quite variable, depending on the ability of the cation to polarize the methine carbon or the electronegativity effect caused by the halogen substituent.

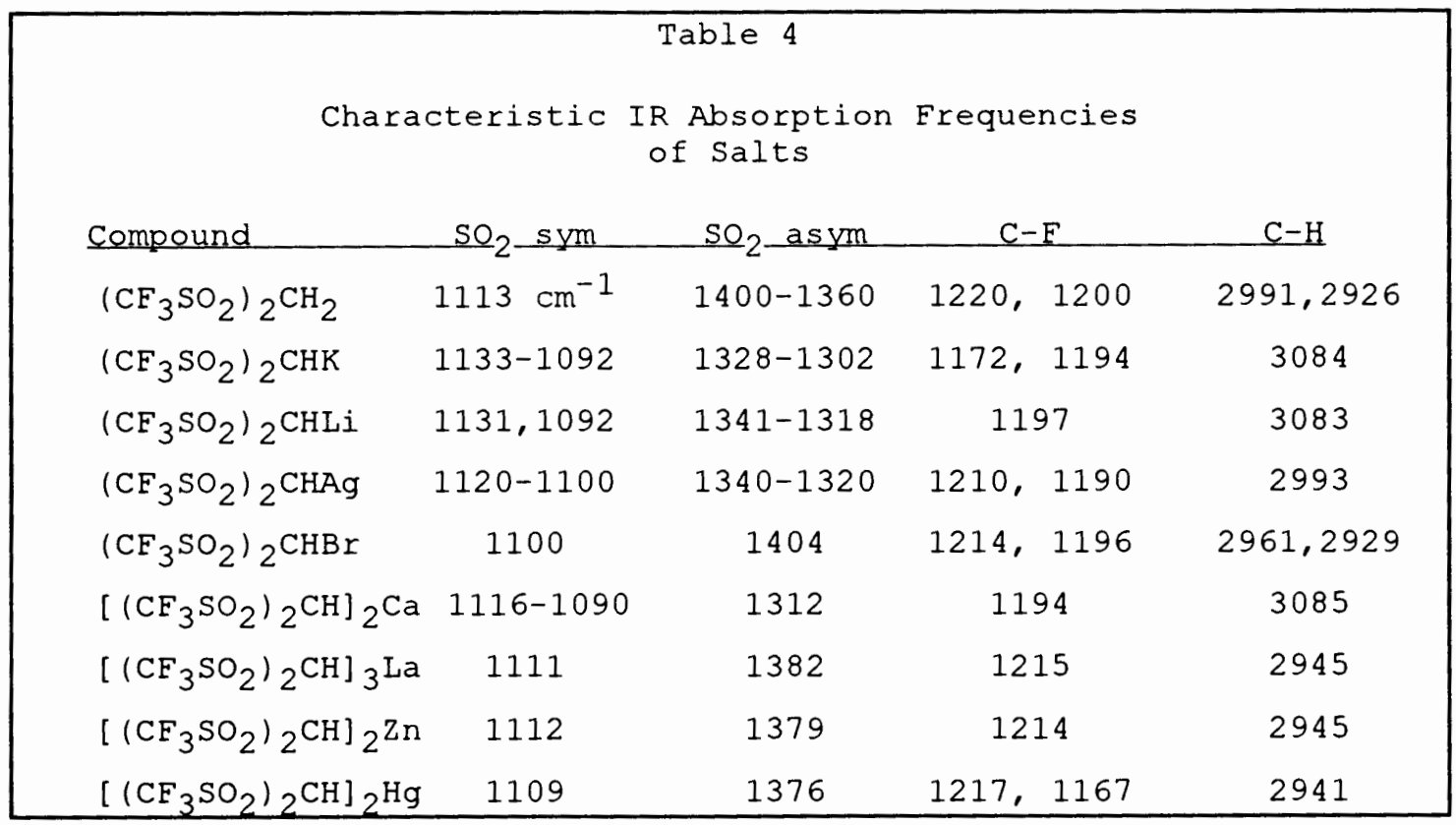

Thus it can be clearly seen that the substituent on the methine carbon can have a great effect on the absorbances of the other groups. It is interesting to 
note that these salts have two distinct structures; one structure where the cation or halogen is bonded or coordinated to the carbon and another structure where the cation forms a complex with the sulfonyl oxygens rather than the carbon. Depending on the substituent and the coordination the infrared region absorbances are affected, e.g. If the metal ion is coordinated to the oxygens it changes absorbances, and if it is coordinated to the methine carbon it affects the $\mathrm{C}-\mathrm{H}$ stretch.

\section{NMR Spectra}

The ${ }^{1} \mathrm{H}$ and ${ }^{19} \mathrm{~F}$ NMR spectra for these compounds are summarized in Table 5. The $\left(\mathrm{CF}_{3} \mathrm{SO}_{2}\right)_{2} \mathrm{CH}_{2}$ has only one peak in both the ${ }^{1} \mathrm{H}$ and ${ }^{19} \mathrm{~F}$ spectra. As substituents are changed the peak position varied over a range of $2 \mathrm{ppm}$ in the ${ }^{1} \mathrm{H}$ spectrum and $15 \mathrm{ppm}$ in the ${ }^{19} \mathrm{~F}$ spectrum. 
Table 5

Characteristic NMR Resonances

Compound ${ }^{1}$ H Chemical shift (ppm) ${ }^{19} \mathrm{E}$ Chemical

Shift (ppm)

$\begin{array}{llr}\left(\mathrm{CF}_{3} \mathrm{SO}_{2}\right)_{2} \mathrm{CH}_{2} & 5.0 & -73.0 \\ \left(\mathrm{CF}_{3} \mathrm{SO}_{2}\right)_{2} \mathrm{CHAg} & 5.0 & -70.2 \\ \left(\mathrm{CF}_{3} \mathrm{SO}_{2}\right)_{2} \mathrm{CHK} & 4.0 & -70.2 \\ \left(\mathrm{CF}_{3} \mathrm{SO}_{2}\right)_{2} \mathrm{CHLi} & 4.1 & -85.0 \\ \left(\mathrm{CF}_{3} \mathrm{SO}_{2}\right)_{2} \mathrm{CHBr} & 6.30 & -64.0 \\ {\left[\left(\mathrm{CF}_{3} \mathrm{SO}_{2}\right)_{2} \mathrm{CH}\right]_{2} \mathrm{Ca}} & 4.0 & -81.9 \\ {\left[\left(\mathrm{CF}_{3} \mathrm{SO}_{2}\right)_{2} \mathrm{CH}\right]_{3} \mathrm{La}} & 4.0 & -81.0 \\ {\left[\left(\mathrm{CF}_{3} \mathrm{SO}_{2}\right)_{2} \mathrm{CH}\right]_{2} \mathrm{Zn}} & 4.0 & -82.3 \\ {\left[\left(\mathrm{CF}_{3} \mathrm{SO}_{2}\right)_{2} \mathrm{CH}\right]_{2} \mathrm{Hg}} & 4.6 & -79.0\end{array}$

All of these compounds gave singlets in both the proton and fluorine spectra. The spectra that were obtained for the alkylation derivatives were very complex and they were compared to known literature values for analogous compounds. The 4,4'-bis(trifluoro methylsulfonyl) butene-1 $\left(\left(\mathrm{CFa}_{3} \mathrm{SO}_{2}\right){ }_{2} \mathrm{CH}^{b} \mathrm{CH}_{2} \mathrm{CH}^{\mathrm{d}}=\mathrm{CH}_{2}{ }_{2}\right)$ had been synthesized previously and had been fully characterized by NMR, $45{ }^{19} \mathrm{~F}$ NMR $\delta_{a}-73.5(s) ;{ }^{1} \mathrm{H}$ NMR $\delta_{b} 4.9$ (t); $\delta_{c} 3.2$ (t); $\delta_{\mathrm{d}} 5.9(\mathrm{~m}) ; \delta_{\mathrm{e}} 5.4(\mathrm{~m})$ so a simple comparison showed that the same compound had been made. The 1,1'bis(trifluoromethylsulfonyl) butane had not been synthesized previously. 
The 4,4'-bis(trifluoro methylsulfonyl)-1,2epoxybutane $\left(\left(\mathrm{CE}_{3} \mathrm{SO}_{2}\right)_{2} \mathrm{CHCH}_{2} \mathrm{CHCH}_{2}\right)$ was a new compound, its 分 proton NMR was compared to $\mathrm{FSO}_{2} \mathrm{CF}_{2} \mathrm{CF}_{2} \mathrm{OCH}_{2} \mathrm{CHCH}_{2}$, which had been previously been made in this laboratory. The proton spectrum was very complex and it was assumed that the correct compound was made based on similarities to the similar compound; with the new compound there is coupling between the methyl fluorines and the protons on the alkyl chain, whereas there is no observed coupling between protons and fluorines in the ether derivative.

\section{Mass spectra}

The mass spectra of these compounds did show a general trend to the fragmentation pattern, the $\left(\mathrm{CF}_{3} \mathrm{SO}_{2}\right)_{2} \mathrm{CH}^{-}$ion was observed in most of the spectra, and most fragment could be accounted for by the loss of $\mathrm{CF}_{3} \mathrm{SO}_{2}$ or $\mathrm{CF}_{3}$ groups. All mass spectra were obtained using fast atom bombardment (FAB); spectra were collected for both positive and negative ions.

The resolution of the instrument was not sufficient to differentiate the isotopes of mercury or sulfur. Mercury has five isotopes that exceed ten percent, 198, 199, 200, 201, and 202, these isotopes should produce a series of five peaks in the mass spectra with relative intensities of $2: 3: 5: 3: 6$ respectively. The mercury salt 
ion fragments were calculated using the mercury isotope with a mass number 202, relative abundance $29.7 \%$, the most abundant isotope.

It should be noted that the mass spectra for the compounds includes ion peaks that exceed the molecular ion mass. These compounds would form dimers and trimers because of the acidic hydrogens and the oxygens. Dimeric and trimeric structures can be easily drawn for the organic derivatives and the acid. The mass spectra data are reported in Table 6 .

Table 6:

Mass Spectra Data

$\left[\left(\mathrm{CF}_{3} \mathrm{SO}_{2}\right)_{2} \mathrm{CH}\right]_{2} \mathrm{Hg}$ M.W. 760

\begin{tabular}{|c|c|c|}
\hline Negative Ions & & \\
\hline Mass & $\frac{o}{\partial}$ Base Peak & Ion \\
\hline 757.7 & 7.5 & $M-2 H$ \\
\hline 505.4 & 1.0 & $\mathrm{M}-\mathrm{H}-\mathrm{SO}_{2} \mathrm{CF}_{3}-\mathrm{CF}_{3}-(\mathrm{F}, 2 \mathrm{O})$ \\
\hline 378.1 & 57.2 & $\begin{array}{c}\mathrm{M}-\mathrm{H}-\mathrm{CH}\left(\mathrm{SO}_{2} \mathrm{CF}_{3}\right)_{2}-\mathrm{CF}_{3}-2 \mathrm{O} \\
\quad \text { or } \mathrm{MF}-\mathrm{H}-3 \mathrm{SO}_{2} \mathrm{CF}_{3}\end{array}$ \\
\hline 311.8 & 48.7 & $\mathrm{M}-\mathrm{C}\left(\mathrm{SO}_{2} \mathrm{CF}_{3}\right)_{2}-2 \mathrm{CF}_{3}-2 \mathrm{O}$ \\
\hline 279.0 & 100.0 & $\mathrm{CH}\left(\mathrm{SO}_{2} \mathrm{CF}_{3}\right)_{2}$ \\
\hline
\end{tabular}


Table 6 (continued)

$\left(\mathrm{CF}_{3} \mathrm{SO}_{2}\right)_{2} \mathrm{CHCH}_{2} \mathrm{CH}_{2} \mathrm{CH}_{3}$ M.W. 322.2

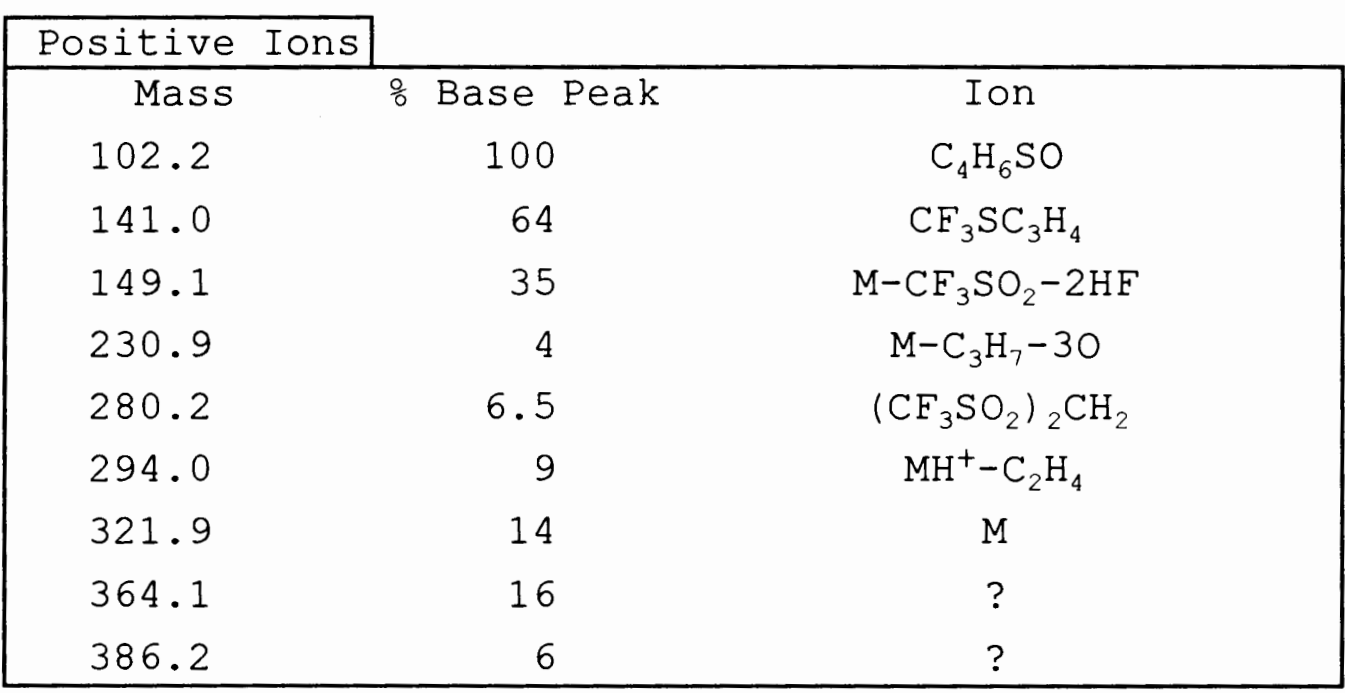

$\left(\mathrm{CF}_{3} \mathrm{SO}_{2}\right)_{2} \mathrm{CH}_{2} \quad$ M.W. 280.2

Positive Ions

Mass

141.0

158.0

198.3

214.0

279.3

391.5

440.4

528.5

555.8

634.1 o Base Peak

24

73

8

100

4

6

5

5

4

7
Ion

$\mathrm{M}-\mathrm{H}-2 \mathrm{CF}_{3}$

$\mathrm{M}-\mathrm{H}-\mathrm{CF}_{3}-2 \mathrm{O}-\mathrm{HF}$

$\mathrm{MH}_{3}{ }^{+}-\mathrm{CF}_{3}$

$\mathrm{M}-\mathrm{SO}_{2}$, $\mathrm{H}$ $\mathrm{M}-\mathrm{H}$ $2 \mathrm{M}-\mathrm{CF}_{3} \mathrm{SO}_{2}-\mathrm{O}-\mathrm{F}$ $2 \mathrm{M}-\mathrm{CF}_{3}-2 \mathrm{O}-\mathrm{F}$ $2 \mathrm{M}-2 \mathrm{O}$ $2 \mathrm{M}-4 \mathrm{H}$

$3 \mathrm{M}-\mathrm{CF}_{3} \mathrm{SO}_{2}-\mathrm{CF}_{3}-4 \mathrm{H}$

Negative Ions

Mass $\frac{\circ}{8}$ Base Peak

278.9

100

210

2

Ion
$\mathrm{M}-\mathrm{H}$
$\mathrm{M}-\mathrm{H}-\mathrm{CF}_{3}$


Table 6 (continued)

$\left(\mathrm{CF}_{3} \mathrm{SO}_{2}\right)_{2} \mathrm{CHCH}_{2} \mathrm{CH}=\mathrm{CH}_{2} \quad$ M.W. 320.2

\begin{tabular}{|ccc|}
\hline Negative Ions & & \\
\hline Mass & : & \\
279.0 & 32 & Ion \\
319.0 & 100 & $\mathrm{M}-\mathrm{CH}_{2} \mathrm{CH}=\mathrm{CH}_{2}$ \\
405.2 & 3 & $\mathrm{M}$ \\
& & $2 \mathrm{M}-\mathrm{CF}_{3} \mathrm{SO}_{2}-\mathrm{CF}_{3}-\mathrm{HF}-\mathrm{CH}$ \\
\hline
\end{tabular}

$\left(\mathrm{CF}_{3} \mathrm{SO}_{2}\right)_{2} \mathrm{CHCH}_{2} \mathrm{CH}=\mathrm{CH}_{2} \quad$ M.W. 320.2

\begin{tabular}{|ccc}
\hline Positive Ions & & \\
\hline Mass & Base Peak & Ion \\
103.1 & 20 & $\mathrm{MH}^{+}-\mathrm{CF}_{3} \mathrm{SO}_{2}-\mathrm{CF}_{3}-\mathrm{O}$ \\
141.0 & 93 & $\mathrm{M}-2 \mathrm{CF}_{3}-\mathrm{C}_{3} \mathrm{H}_{5}$ \\
149.1 & 22 & $\mathrm{M}-\mathrm{CF}_{3} \mathrm{SO}_{2}-\mathrm{C}_{3} \mathrm{H}_{2}$ \\
158.0 & 100 & $\mathrm{M}-\mathrm{CF}_{3} \mathrm{SO}_{2}-\mathrm{C}_{2} \mathrm{H}_{5}$ \\
167.2 & 8 & $\mathrm{M}-\mathrm{H}-2 \mathrm{CF}_{3}-\mathrm{CH}_{2}$ \\
198.4 & 9 & $\mathrm{M}-\mathrm{H}-\mathrm{CF}_{3}-2 \mathrm{O}-\mathrm{HF}$ \\
214.1 & 18 & $\mathrm{M}-\mathrm{H}-\mathrm{CF}_{3}-2 \mathrm{H}_{2} \mathrm{O}$ \\
255.2 & 9 & $\mathrm{MF}+-\mathrm{CF}_{3}-\mathrm{CH}$ \\
279.3 & 4 & $\left(\mathrm{CF}_{3} \mathrm{SO}_{2}\right){ }_{2} \mathrm{CH}$ \\
418.2 & 7 & $2 \mathrm{M}-\mathrm{CF}_{3} \mathrm{SO}_{2}-\mathrm{CF}_{3}-\mathrm{HF}$
\end{tabular}




\section{Elemental Analysis}

Some of the values that were obtained from elemental analysis were in poor agreement to the calculated values. However, there were possible side products that would have been hard to remove or detect. For products (III) and (VII) water added to the formula would have given better agreement. For the formula $\left[\left(\mathrm{CF}_{3} \mathrm{SO}_{2}\right)_{2} \mathrm{CH}\right]_{2} \mathrm{Ca} \cdot 1.5 \mathrm{H}_{2} \mathrm{O}$ calculated values $\frac{\circ}{\circ} \mathrm{C} 1.52, \circ \mathrm{F} 36.45$, $\circ \mathrm{H} 0.81$ found values \% $10.72, \frac{\circ}{\circ} \mathrm{F} 36.6, \frac{8}{0} \mathrm{H} 0.75$ which is an improvement. For (VII) if seven waters are added, an improvement is seen in the calculated values $\frac{\circ}{0} \mathrm{C} 9.81, \circ \mathrm{F} 31.02, \circ \mathrm{H} 1.55$ versus found values $\frac{\circ}{\circ} 9.80, \frac{\circ}{\circ}$ 30.4, $\frac{\circ}{\circ} \mathrm{H} 1.11$. For products (IX) and $(X)$, the reactions were much more complex and a vast array of side products were possible.

For (IX) it was found that the sample may have been contaminated with one part $\left(\mathrm{CF}_{3} \mathrm{SO}_{2}\right)_{2} \mathrm{C}\left(\mathrm{CH}_{2} \mathrm{CH}=\mathrm{CH}_{2}\right)_{2}$ to two parts $\left(\mathrm{CF}_{3} \mathrm{SO}_{2}\right)_{2} \mathrm{CHCH}_{2} \mathrm{CH}=\mathrm{CH}_{2}$ (36\% by weight). This side product is reasonable and gives a good agreement to the values that were found, calculated $\frac{\circ}{\circ} 25.2$, $\frac{\circ}{F} 34.17, \circ \mathrm{H}$ 2.22 versus the found values $\frac{\circ}{0} \mathrm{C} 25.23, \frac{\circ}{0} \mathrm{~F} 33.4,8 \mathrm{H} 2.41$. For $\left(\mathrm{CF}_{3} \mathrm{SO}_{2}\right)_{2} \mathrm{CHCH}_{2} \mathrm{CH}_{2} \mathrm{CH}_{3}$ (X) it was found that the sample was possibly contaminated with $\left(\mathrm{CF}_{3} \mathrm{SO}_{2}\right){ }_{2} \mathrm{CHHgI}$ (30\% by weight). This contaminant is stable and gives a good agreement to the values that were found, calculated $\frac{}{5} \mathrm{C}$ 16.44, $\frac{\circ}{\circ} 29.39$, ㄱ 1.66 versus the found values $\frac{\circ}{\circ}$ 16.49, 
을 29.20, 8H 1.43. Elemental Analysis data is presented in Table 7 .

Table 7:

Elemental Analysis

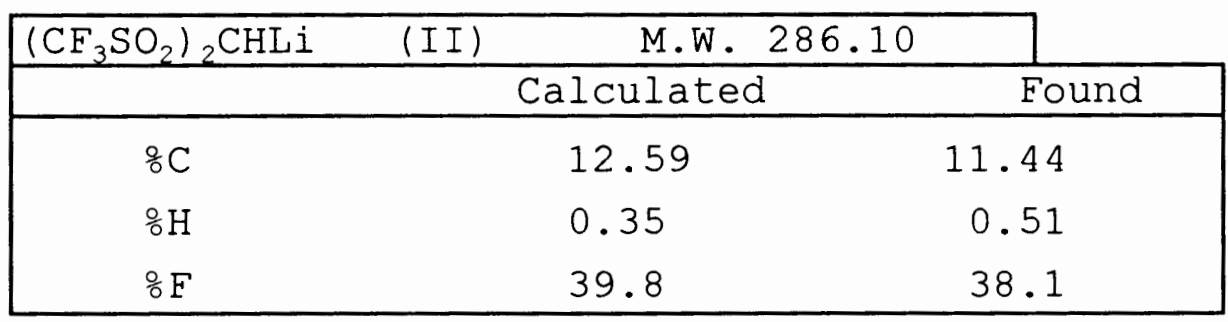

\begin{tabular}{|c|c|c|}
\hline \multicolumn{3}{|c|}{$\left[\left(\mathrm{CF}_{3} \mathrm{SO}_{2}\right)_{2} \mathrm{CH}\right]_{2} \mathrm{Ca} \cdot 1.5 \mathrm{H}_{2} \mathrm{O}$ (III) $\mathrm{M} . \mathrm{W} .598 .40$} \\
\hline & Calculated & Foun \\
\hline$\frac{\circ}{0} \mathrm{C}$ & 11.52 & 10.72 \\
\hline$\circ \mathrm{H}$ & 0.81 & 0.75 \\
\hline$\frac{\circ}{\circ} \mathrm{F}$ & 36.5 & 36.6 \\
\hline
\end{tabular}

\begin{tabular}{|ccc|}
\hline$\left[\left(\mathrm{CF}_{3} \mathrm{SO}_{2}\right)_{2} \mathrm{CH}\right]_{2} \mathrm{Hg}$ & $(\mathrm{IV}) \mathrm{M} . \mathrm{W} .758 .91$ & \\
\hline & Calculated & Found \\
\hline$\% \mathrm{C}$ & 9.50 & 9.27 \\
$\circ \mathrm{H}$ & 0.27 & 0.46 \\
$\circ \mathrm{F}$ & 30.04 & 29.3 \\
$\circ \mathrm{S}$ & 16.90 & 16.33 \\
\hline
\end{tabular}

\begin{tabular}{|c|c|c|}
\hline$\left[\left(\mathrm{CF}_{3} \mathrm{SO}_{2}\right)\right.$ & (VII) & \\
\hline & Calculated & Found \\
\hline$\circ \mathrm{C}$ & 9.81 & 9.80 \\
\hline$\% \mathrm{H}$ & 1.55 & 1.11 \\
\hline$\frac{a}{8} \mathrm{~F}$ & 31.02 & 30.4 \\
\hline
\end{tabular}


Table 7 (continued)

\begin{tabular}{|ccc|}
\hline$\left(\mathrm{CF}_{3} \mathrm{SO}_{2}\right)_{2} \mathrm{CHCH}_{2} \mathrm{CH}=\mathrm{CH}_{2}$ & (IX) & M.W. 320.23 \\
\hline & Calculated & Found \\
\hline$\frac{8}{8}$ & 22.50 & 25.23 \\
$\frac{8}{8}$ & 1.89 & 2.41 \\
$8 \mathrm{~F}$ & 35.6 & 33.4 \\
\hline
\end{tabular}

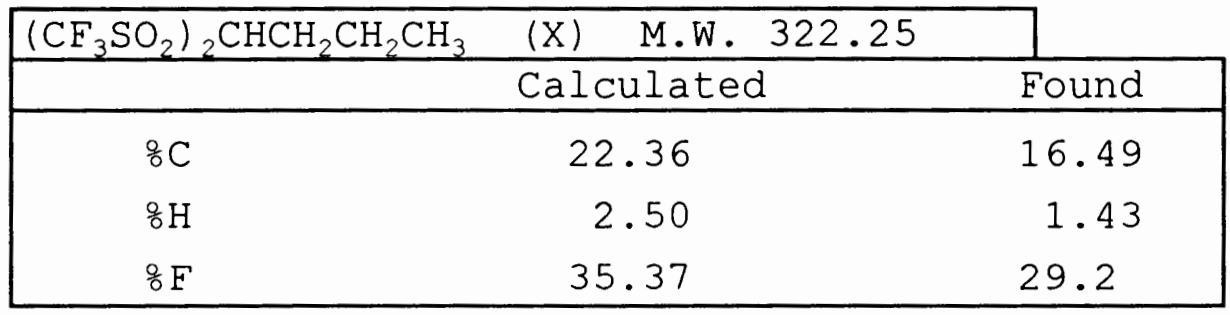

An attempt to synthesize the acidic form of (XIII) was made. This resulted in a dark brown liquid product which appears to be analogous to the chlorohydrin $\mathrm{ClCH}_{2} \mathrm{CH}(\mathrm{OH}) \mathrm{CH}_{2} \mathrm{OCF}_{2} \mathrm{CF}_{2} \mathrm{SO}_{2} \mathrm{~F}$ which was prepared by Nick Hamel. The acid form of (XIII) shows a sharp weak absorbance near $3600 \mathrm{~cm}^{-1}$ that could be attributed to a partially protected hydroxyl group, or one that is not hydrogen bonded and a broad absorbance at $3413 \mathrm{~cm}^{-1}$, which is attributable to the portion of the hydroxyl that can hydrogen bond. These results are similar to those found for a dilute solution of cyclohexylcarbinol in $\mathrm{CCl}_{4} \cdot{ }^{53}$ To determine the most probable structure for the product of $\left(\mathrm{CF}_{3} \mathrm{SO}_{2}\right)_{2} \mathrm{CHMgBr}+\mathrm{BrCHCH}_{2} \mathrm{CHCH}_{2} \mathrm{O}$ it is helpful to examine the reactions that epoxides undergo in the presence of acids and bases. The epoxide ring would have 
opened in the presence of $\mathrm{HCl}$ to form the terminal chloride and the hydroxyl on the second carbon. This is supported in the IR because there is a broad absorbance at $3413 \mathrm{~cm}^{-1}$, a sharp peak at $3599 \mathrm{~cm}^{1}$ and a weak absorbance at $744 \mathrm{~cm}^{-1}$ which indicates an intermolecular bonded $\mathrm{OH}$. There is also a "free" $\mathrm{OH}$, and a $\mathrm{C}-\mathrm{Cl}$ bond in the compound respectively. A free hydroxyl can be explained by the fact that there may be steric hindrances that would keep the hydroxyl group from forming hydrogen bonding, as in 2,6-di-t-butylphenol. By comparing the structure with 2,6-di-t-butylphenol it is likely that the steric hindrances would be similar in these two compounds, as illustrated in Eigure 8 .

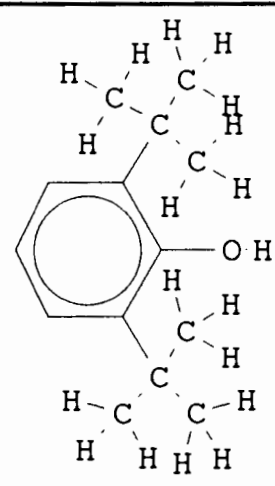

a) 2,6-di-t-butylphenol

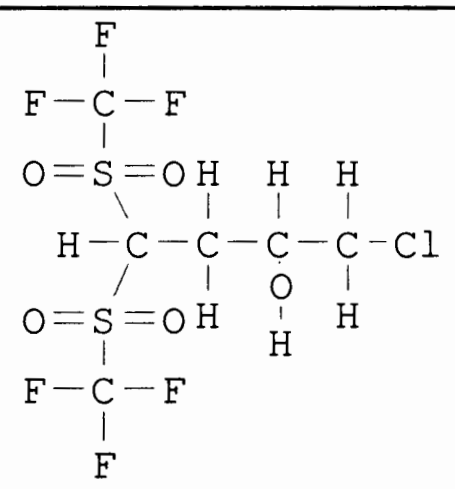

b) 1,1-bis (trifluoromethylsulfonyl) -4-chloro-2-butanol

Figure 8: Analogous structures of hindered alcohols 
Also the peaks that are characteristic of an epoxide, 3084 $\mathrm{cm}^{-1}, 1311 \mathrm{~cm}^{-1}, 1262 \mathrm{~cm}^{-1}$, and $965 \mathrm{~cm}^{-1}$, are missing from the spectrum after the reaction is quenched with $\mathrm{HCl}$. If the reaction is not quenched with $\mathrm{HCl}$, the absorbances characteristic of epoxides are visible in spectra of the product as in the case of (XIII).

In the case of epoxide ring opening in the presence of bases, the reaction is carried out with a Grignard reagent which is a very strong base. It is strong enough to cause the ring to open, forming a $\beta$-substituted alcohol after hydrolysis. This would possibly provide additional shielding for the hydroxyl group which would result in the observed "free" hydroxyl. These reactions are shown in Equations (27) and (28).

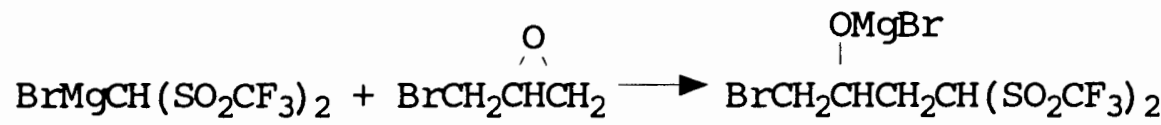

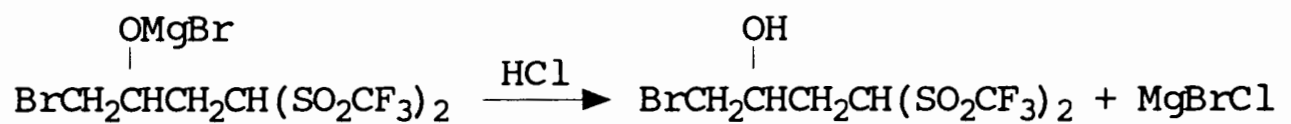




\section{Chapter 6 \\ Synthesis of $\left(\mathrm{CF}_{3} \mathrm{SO}_{2} \mathrm{~L}_{2} \mathrm{CH}_{2}\right.$ Salts}

Preparation of $\left(\mathrm{CE}_{3} \mathrm{SO}_{2} \mathrm{~L}_{2} \mathrm{CHK}\right.$ (I)

$6.0 \mathrm{~g}$ (43.5 mmols) of $\mathrm{K}_{2} \mathrm{CO}_{3}$ were finely ground and suspended in $50 \mathrm{ml}$ of ethanol. To this was added $10.2 \mathrm{~g}$ (36.4 mmols) of bis(trifluoromethylsulfonyl)methane (sublimed) dissolved in $20 \mathrm{ml}$ of ethanol. The reaction mixture was stirred in a $250 \mathrm{ml}$ round bottom flask containing a magnetic stir bar, at room temperature for 2 hours. The mixture was suction filtered and the ethanol was removed from the supernatant liquid by rotary evaporation, followed by drying at $80^{\circ} \mathrm{C}$ under high vacuum for 1 day. $9.5 \mathrm{~g}$ of product were recovered. Characterization of $\left(\mathrm{CF}_{3} \mathrm{SO}_{2} \mathrm{~L}_{2} \mathrm{CHb} \mathrm{K}\right.$

${ }^{19} \mathrm{~F} \operatorname{NMR}\left(\mathrm{CD}_{3} \mathrm{CN}\right) \delta_{\mathrm{a}}-81.9(\mathrm{~s}) ;{ }^{1} \mathrm{H} \operatorname{NMR}\left(\mathrm{CD}_{3} \mathrm{CN}\right) \delta_{\mathrm{b}} 4.0(\mathrm{~s}) ;$ IR 3084 (m), 1328 (s), 1302 (s), 1194 (s), 1172 (s), 1133 (m), $1092(\mathrm{~m}), 964(\mathrm{~s}), 833(\mathrm{~m}), 647(\mathrm{~m}), 582(\mathrm{~m}) \mathrm{cm}^{-1}$; MP $268^{\circ} \mathrm{C}, \operatorname{dec} 295^{\circ} \mathrm{C}$. The characterization agrees with literature values. 37 Preparation of $\left(\mathrm{CF}_{3} \mathrm{SO}_{2} \mathrm{~L}_{2} \mathrm{CHLi}\right.$ (II)

To $0.45 \mathrm{~g}$ ( $6.25 \mathrm{mmols})$ of finely ground $\mathrm{Li}_{2} \mathrm{CO}_{3}$, were added $17.0 \mathrm{ml}(6.07 \mathrm{mmols})$ of a $10 \%$ aqueous solution of bis(trifluoromethylsulfonyl)methane (sublimed). The reaction mixture was stirred in a $25 \mathrm{ml}$ round bottom flask containing a magnetic stir bar, at room temperature for 3 
weeks. The mixture was suction filtered and the water was removed from the supernatant liquid by rotary evaporation, followed by drying at $100^{\circ} \mathrm{C}$ under high vacuum for 20 hours. The product was recrystallized from ethanol to give $1.04 \mathrm{~g}(3.6 \mathrm{mmols})$ product.

Characterization of $\left(\mathrm{CF}_{3} \mathrm{SO}_{2} \mathrm{~L}_{2} \mathrm{CH}^{\mathrm{kLI}}\right.$

${ }^{19} \mathrm{~F} \operatorname{NMR}\left(\mathrm{CD}_{3} \mathrm{CN}\right) \delta_{\mathrm{a}}-85.0(\mathrm{~s}) ; \operatorname{IR} 3083(\mathrm{w}), 1341$ (s), 1318 (s), 1197 (s), 1131 (m), 1092 (m), 982 (m), 845 (w), $657(\mathrm{~m}), 583(\mathrm{~m}) \mathrm{cm}^{-1} ; \mathrm{mp} 280^{\circ} \mathrm{C}$ dec. Preparation of $\left[\left(\mathrm{CE}_{3} \mathrm{SO}_{2} \mathrm{~L}_{2} \mathrm{CH}_{2} \mathrm{Ca}\right.\right.$ (III)

Freshly distilled xylene $(7 \mathrm{ml})$ and $0.28 \mathrm{~g}(6.7$ mmols) $\mathrm{CaH}_{2}$ were added to a three neck round bottom flask fitted with a drying tube, a reflux column and a Teflon magnetic stir bar. $17.3 \mathrm{ml}$ of a 10 \% solution of $\left(\mathrm{CF}_{3} \mathrm{SO}_{2}\right)_{2} \mathrm{CH}_{2}$ in xylene was added dropwise over one hour. The reaction was stirred at reflux until gas evolution ceased. The reaction mixture was stirred for three weeks protected from air by an air trap. Following filtration under nitrogen the product was recrystallized from ethanol, dried at $100^{\circ} \mathrm{C}$ under vacuum yielding $1.98 \mathrm{~g}$ (3.31 mols) product in a quantitative yield.

Characterization of $\left[\left(\mathrm{CF}_{3}^{\mathrm{a}} \mathrm{SO}_{2} \mathrm{~L}_{2} \mathrm{CH}^{\mathrm{b}} \mathrm{I}_{2} \mathrm{Ca}\right.\right.$ ${ }^{19} \mathrm{~F} \operatorname{NMR}\left(\mathrm{CD}_{3} \mathrm{CN}\right) \delta_{\mathrm{a}}-81.9(\mathrm{~s}) ;{ }^{1} \mathrm{H} \operatorname{NMR}\left(\mathrm{CD}_{3} \mathrm{CN}\right) \delta_{\mathrm{b}} 4.0(\mathrm{~s}) ;$ IR 3086 (m), (1624 (m) $\left.\mathrm{CH}_{3} \mathrm{CN}\right) 1312$ (s), 1194 (s), 1116 (m), $1090(\mathrm{~m}), 975$ (s), 846 (m), 650 (m), 579 (s) $\mathrm{cm}^{-1}$. 
Preparation of $\left[\left(\mathrm{CF}_{3} \mathrm{SO}_{2} \mathrm{~L}_{2} \mathrm{CH}_{2} \mathrm{Hg}\right.\right.$ (IV)

$$
2.30 \mathrm{~g} \mathrm{HgO}(10.6 \mathrm{mmols}), 6.04 \mathrm{~g}(21.6 \mathrm{mmols}) \text { freshly }
$$

sublimed $\left(\mathrm{CF}_{3} \mathrm{SO}_{2}\right)_{2} \mathrm{CH}_{2}$ and $15 \mathrm{ml}$ deionized water were added to a $75 \mathrm{ml}$ Pyrex reaction vessel containing a Teflon magnetic stir bar. The reaction was stirred at room temperature for 18 hours. The water was removed under high vacuum. The product was heated to $110^{\circ} \mathrm{C}$ and pumped to $10 \mu \mathrm{m} \mathrm{Hg}$ for 6 hours to give $7.92 \mathrm{~g}$ (10.44 mmols) of product in a $98 \%$ yield.

Characterization of $\left[\left(\mathrm{CEa}_{3} \mathrm{SO}_{2} \perp_{2} \mathrm{CH}^{2}\right]_{2} \mathrm{Hg}\right.$

${ }^{19} \mathrm{~F} \operatorname{NMR}\left(\mathrm{CD}_{3} \mathrm{CN}\right) \delta_{\mathrm{a}}-81.9(\mathrm{~s}) ;{ }^{1} \mathrm{H} \operatorname{NMR}\left(\mathrm{CD}_{3} \mathrm{CN}\right) \delta_{\mathrm{b}} 4.0(\mathrm{~s}) ;$ $\operatorname{MS}(F A B) \mathrm{m} / \mathrm{z} 757.7(\mathrm{M}-\mathrm{H})^{-} ; \quad 505.4\left(\mathrm{M}-\left(\mathrm{CF}_{3} \mathrm{SO}_{2}\right)_{2} \mathrm{C}\right)^{-} ; 378.1$ $\left(\mathrm{CF}_{3} \mathrm{SO}_{2} \mathrm{CHSHg}\right)^{-} ; 311.8\left(\mathrm{M}-\mathrm{C}_{2} \mathrm{~F}_{5}+3 \mathrm{SO}_{2}\right)^{-} ; 279.0\left(\left(\mathrm{CF}_{3} \mathrm{SO}_{2}\right)_{2} \mathrm{CH}\right)^{-}$ ; IR 2941 (w), 1376 (s), 1217 (s), 1166 (m), 1109 (s), $1009(\mathrm{~m}), 794(\mathrm{~m}), 746(\mathrm{~m}), 654(\mathrm{~m}), 639(\mathrm{~m}), 580(\mathrm{~m}) \mathrm{cm}^{-1}$. Preparation of $\left(\mathrm{CE}_{3} \mathrm{SO}_{2} \mathrm{~L}_{2} \mathrm{CHBr}(\mathrm{V})\right.$

Method 1

$2.30 \mathrm{~g}\left[\left(\mathrm{CF}_{3} \mathrm{SO}_{2}\right)_{2} \mathrm{CH}\right]_{2} \mathrm{Hg}(10.4$ mmols $)$ and $4.53 \mathrm{~g}$ of dry $\mathrm{Br}_{2}$ were added to a $75 \mathrm{ml}$ Pyrex reaction vessel containing a Teflon magnetic stir bar. The reaction mixture was stirred at room temperature for 6 hours. $6.85 \mathrm{~g}$ of crude product was vacuum transferred to a $25 \mathrm{ml}$ round flask, and was shaken with $\mathrm{Hg}$ to remove excess bromine. To give 3.77 g of crude product. The crude product was distilled at 
$75^{\circ} \mathrm{C}$ under dynamic vacuum to give $3.59 \mathrm{~g}(10.00 \mathrm{mmols})$ of product in a 48 \% yield.

Method 2

$13.61 \mathrm{~g}(42.79$ mmols $)$ finely ground $\left(\mathrm{CF}_{3} \mathrm{SO}_{2}\right)_{2} \mathrm{CHK}$ in a $100 \mathrm{ml}$ round bottom flask equipped with a Teflon coated stir bar was suspended in $30 \mathrm{ml}$ of $\mathrm{CCl}_{4} \cdot 7.01 \mathrm{~g}(87.6$ mmols) $\mathrm{Br}_{2}$ dissolved in $10 \mathrm{ml} \mathrm{CCl}_{4}$ was added to the suspension slowly over five minutes. The reaction mixture was stirred until all bromine color was gone. Following filtration of the solid material the crude product was isolated by distilling off the bulk of the $\mathrm{CCl}_{4}$ at atmospheric pressure. The final product was distilled at $90^{\circ} \mathrm{C}(24 \mathrm{~mm} \mathrm{Hg})$ to yield $10.59 \mathrm{~g}(29.42 \mathrm{mmols})$ product in a 69 \% yield.

Both methods yielded a liquid product; the product obtained from method 1 was clear, the product obtained from method 2 was yellow. The spectra (IR and NMR) were identical for both products.

Characterization of $\left(\mathrm{CF}_{3} \mathrm{SO}_{2} \perp_{2} \mathrm{CHBr}\right.$

${ }^{19} \mathrm{~F} \operatorname{NMR}\left(\mathrm{CDCl}_{3}\right) \delta_{\mathrm{a}}-64.0(\mathrm{~s}) ;{ }^{1} \mathrm{H} \operatorname{NMR}\left(\mathrm{CDCl}_{3}\right) \delta_{\mathrm{b}} 6.30$ (s); $\operatorname{IR} 2961(\mathrm{w}), 2928$ (w), 1403 (s), 1220 (s), 1105 (s), 776 $(\mathrm{w}), 722(\mathrm{~m}), 680$ (w), 627 (w), 576 (m) $\mathrm{cm}^{-1}$.

Preparation of $\mathrm{Ag}_{2} \mathrm{CO}_{3}$ (VI)

To a single neck $250 \mathrm{ml}$ round bottom flask containing a Teflon coated stir bar were added $17.35 \mathrm{~g}$ (102.14 mmols) 
$\mathrm{AgNO}_{3}$ and $50 \mathrm{ml}$ distilled water. The reaction mixture was stirred at room temperature until all $\mathrm{AgNO}_{3}$ was dissolved. $150 \mathrm{ml}$ of a saturated aqueous solution of $\mathrm{NaHCO}_{3}$ was added slowly over one hour; addition was stopped when no further solid was precipitated upon further addition. The precipitate was washed with fresh water five times. Following filtration and drying in the oven at $110^{\circ} \mathrm{C}$ for 6 hours $14.08 \mathrm{~g}(50.2 \mathrm{mmols})$ were recovered in a $98 \%$ yield. Characterization of $\mathrm{Ag}_{2} \mathrm{CO}_{3}$

IR 1437 (s), 1090 (m), 861 (s), 744 (m) Preparation of $\left(\mathrm{CF}_{3} \mathrm{SO}_{2} \mathrm{~L}_{2} \mathrm{CHAg}\right.$ (VII)

To a $250 \mathrm{ml}$ single neck round bottom flask containing a stir bar were added $14.08 \mathrm{~g}$ (50.2 mmols) $\mathrm{Ag}_{2} \mathrm{CO}_{3}$ and 150 ml methanol. The resulting suspension was stirred at room temperature with slow addition of a solution of $14.20 \mathrm{~g}$ (50.7 mmols) of $\left(\mathrm{CF}_{3} \mathrm{SO}_{2}\right)_{2} \mathrm{CH}_{2}$ dissolved in $25 \mathrm{ml}$ methanol. The reaction mixture was stirred in the dark for 48 hours. The precipitate was filtered and the methanol was removed from the supernatant liquid by rotary evaporation in the dark followed by drying at $100^{\circ} \mathrm{C}$ under vacuum to yield $19.4 \mathrm{~g}$ of product in a quantitative yield. Characterization of $\left(\mathrm{CF}_{3} \mathrm{SO}_{2}{ }_{2} \mathrm{CHAg}\right.$

IR 2993 (VW), 1332 (s), 1193 (s), 1125 (m), 1100 (m), $883(\mathrm{~m}), 771(\mathrm{w}), 687(\mathrm{~m}), 626(\mathrm{w}), 582(\mathrm{~m})$ The spectrum agreed with literature values. ${ }^{35}$ 
Preparation of $\left[\left(\mathrm{CF}_{3} \mathrm{SO}_{2} \perp_{2} \mathrm{CH}_{3} \mathrm{La}\right.\right.$ (VIII)

To a $50 \mathrm{ml}$ single neck round bottom flask containing a stir bar were added $0.79 \mathrm{~g}(1.72 \mathrm{mmols}) \mathrm{La}_{2}\left(\mathrm{CO}_{3}\right)_{3}$ and 15 $\mathrm{ml}$ ethanol. To the resulting suspension was added $28.5 \mathrm{ml}$ of a $10.2 \%$ (wt/wt) methanol solution of $\left(\mathrm{CF}_{3} \mathrm{SO}_{2}\right)_{2} \mathrm{CH}_{2}$ (10.4 mmols). The reaction mixture was stirred at room temperature for 4 days. The solution was filtered and most of the ethanol was removed from the filtrant by rotary evaporation followed by drying at $100^{\circ} \mathrm{C}$ under vacuum to yield $3.3 \mathrm{~g}$ of product in a quantitative yield. Characterization of $\left[\left(\mathrm{CE}_{3} \mathrm{SO}_{2} \mathrm{~L}_{2} \mathrm{CH}_{3} \mathrm{La}\right.\right.$

IR 2993 (VW), 1332 (s), 1193 (s), 1125 (m), 1100 (m), $883(\mathrm{~m}), 771(\mathrm{w}), 687(\mathrm{~m}), 626(\mathrm{w}), 582(\mathrm{~m})$ Preparation of $\left(\mathrm{CF}_{3} \mathrm{SO}_{2} \mathrm{~L}_{2} \mathrm{CHCH}_{2} \mathrm{CH}=\mathrm{CH}_{2}\right.$ (IX) With Grignard Reagent

To a $250 \mathrm{ml}$ three neck round bottom flask, fitted with a drying tube, a dry nitrogen line, and containing a Teflon coated magnetic stir bar were added $4.40 \mathrm{~g}$ of $\left(\mathrm{CF}_{3} \mathrm{SO}_{2}\right)_{2} \mathrm{CH}_{2}(15.7 \mathrm{mmols})$ and $6 \mathrm{ml}$ tetrahydrofuran. After flushing the system with nitrogen $22.5 \mathrm{ml}$ of $2.5 \mathrm{M} \mathrm{CH}_{3} \mathrm{MgCl}$ in THF was added over a period of one hour via an addition funnel. The reaction mixture was stirred until gas evolution ceased. At which point $4.5 \mathrm{ml}$ allyl bromide (52.0 mmols) was added (addition funnel). A reflux column was fitted in place of the addition funnel and the system 
was again flushed with nitrogen. The reaction was stirred under reflux for 1.5 hours, at $100^{\circ} \mathrm{C}$. The reaction was cooled by addition of ice to the round bottom flask, and the reactants were hydrolyzed by the addition of $80 \mathrm{ml}$ of $3 \mathrm{~N} \mathrm{HCl}$. The organic layer was drawn off and distilled to remove the bulk of the solvent. The crude product 19.74 g) was stirred with water overnight and extracted with diethyl ether; the etherate was then dried over anhydrous $\mathrm{MgSO}_{4}$. The dried etherate was distilled at atmospheric pressure to remove the ether followed by distillation at $93^{\circ} \mathrm{C}(20 \mathrm{mmHg})$ to give $1.06 \mathrm{~g}$ of product.

Characterization of $\left(\mathrm{CE}_{3} \mathrm{SO}_{2}\right)_{2} \mathrm{CHCH}_{2} \mathrm{CH}=\mathrm{CH}_{2}$

$\operatorname{IR} 2992(\mathrm{~m}), 2929(\mathrm{~m}), 1646(\mathrm{w}), 1617(\mathrm{w}), 1398(\mathrm{~s}), 1216$ (s), 1115 (s), $992(w), 938(w), 827(w), 778(m), 742$ (m), 729 (m); MS (FAB) $319(\mathrm{M}-\mathrm{H})^{-}, 279\left(\mathrm{M}-\mathrm{CH}_{2} \mathrm{CHCH}_{2}\right)^{-}, 158$ $\left(\mathrm{CF}_{3} \mathrm{SO}_{2} \mathrm{CHC}\right)^{+}, 141\left(\mathrm{CFSO}_{2} \mathrm{CH}_{2} \mathrm{~S}\right)^{+}$; The spectrum agreed with literature values. 37

Preparation of $\left(\mathrm{CE}_{3} \mathrm{SO}_{2} \mathrm{~L}_{2} \mathrm{CHCH}_{2} \mathrm{CH}_{2} \mathrm{CH}_{3}-\mathrm{X}\right)$

To a single neck $35 \mathrm{ml}$ round bottom flask equipped with a reflux condenser and a stir bar was added $3.04 \mathrm{~g}$ $\left[\left(\mathrm{CF}_{3} \mathrm{SO}_{2}\right)_{2} \mathrm{CH}\right]_{2} \mathrm{Hg}(4.01$ mmols) and $6.4 \mathrm{~g}$ 1-iodopropane $(37.6$ mols) as a reactant and solvent. When the reaction mixture became too viscous to stir, $12 \mathrm{~g}$ of $\mathrm{CHCl}_{3}$ was added and the reaction was stirred for 12 hours. The reaction mixture became pale yellow $\left(\mathrm{Hg}_{2} \mathrm{I}_{2}\right)$ and was heated 
to reflux temperature and held there for four hours. During the reflux period bright red crystals $\left(\mathrm{HgI}_{2}\right)$ began to form. The reaction was stopped and allowed to cool to room temperature, the liquid contents of the flask were removed and the solvent was distilled off. The product was a pale white waxy solid which resisted distillation and sublimation; it was heated to $80^{\circ} \mathrm{C}(10 \mu \mathrm{m} \mathrm{Hg})$ for six hours to yield $1.8 \mathrm{~g}$ product in a $70 \%$ yield.

Characterization of $\left(\mathrm{CF}_{3} \mathrm{SO}_{2} \perp_{2} \mathrm{CHCH}_{2} \mathrm{CH}_{2} \mathrm{CH}_{3}\right.$ IR 3082 (w), 2979 (w), 2941 (w), 2889 (w), 1614 (m), $1377,1365 \mathrm{dblt}(\mathrm{s}), 1329,1310 \mathrm{dblt}(\mathrm{s}), 1195$ (s), 1184 (s), $1100,1094 \operatorname{dblt}(\mathrm{s}), 1027(\mathrm{~m}), 963(\mathrm{~m}), 792(\mathrm{~m}), 746(\mathrm{~m})$, $698(\mathrm{~m}), 653(\mathrm{~m}), 580(\mathrm{~m}) ; \mathrm{MS}(\mathrm{FAB}) 322(\mathrm{M}+\mathrm{H})+$, 364 $\left(\mathrm{M}+\mathrm{C}_{3} \mathrm{H}_{6}\right)+, 294\left(\mathrm{M}-\mathrm{C}_{2} \mathrm{H}_{4}\right)^{+}, 280\left(\left(\mathrm{CF}_{3} \mathrm{SO}_{2}\right)_{2} \mathrm{CH}_{2}\right)^{+}, 141$ $\left(\mathrm{CFSO}_{2} \mathrm{CH}_{2} \mathrm{~S}\right)^{+}, \quad 102\left(\mathrm{C}_{3} \mathrm{H}_{6} \mathrm{SO}\right)^{+}$;

Preparation of $\mathrm{AgF}$ (XI)

To a $500 \mathrm{ml}$ Teflon beaker containing a Teflon coated stir bar were added $6.08 \mathrm{~g}(22.0 \mathrm{mmols}) \mathrm{Ag}_{2} \mathrm{CO}_{3}$ and $15 \mathrm{ml}$ water. The suspension was stirred at room temperature and $10 \mathrm{ml} 48 \%$ aqueous hydrofluoric acid was slowly added over 30 minutes until gas evolution ceased. The reaction mixture was stirred in the dark for 1 hour and then filtered with filter paper in a Nalgene funnel. The filtrant was then heated at $110^{\circ} \mathrm{C}$ under a stream of dry air, with stirring in a Teflon beaker, to dryness. The 
solid crude product was washed three times with $20 \mathrm{ml}$ of dry methanol. The crude solid and the methanol solutions were extracted four times with $10 \mathrm{ml}$ of diethyl ether. The resulting yellow/brown solid was placed in a poly(ethylene) vacuum flask and dried under vacuum to remove the solvents; to give $4.06 \mathrm{~g}$ (32 mols)of product in a 73응 yield. The color and appearance agreed with literature. 54

Preparation of $\mathrm{FSO}_{2} \mathrm{CF}_{2} \mathrm{CF}_{2} \mathrm{OCH}_{2} \mathrm{CHCH}_{2}$ (XII)

To a $75 \mathrm{ml}$ pyrex glass reaction vessel was added 7.00 g (55.2 mmols) of finely ground AgF. The AgF was dried overnight at $100^{\circ} \mathrm{C}$ under high vacuum. $10 \mathrm{ml}$ of dry diglyme (bis(2-methoxyethyl)ether) was added as a solvent, followed by static vacuum transfer addition of $10.91 \mathrm{~g}$ (60.6 mmols) of TEE sultone, $\mathrm{OCF}_{2} \mathrm{CF}_{2} \mathrm{SO}_{2}$. The reaction mixture was stirred at $40^{\circ} \mathrm{C}$ for 5 hours. $8.10 \mathrm{~g} \quad(59.1$ mmols) of epibromohydrin was added by static vacuum transfer. The reaction was stirred in the dark at $40^{\circ} \mathrm{C}$ for 48 hours. The reaction vessel was vented to the atmosphere followed by the removal of volatile materials under dynamic vacuum transfer to a cold trap cooled in liquid nitrogen. The product was transferred to a separatory funnel where it was washed three times with water followed by a continuous liquid/liquid extraction with water to remove all solvent and residual water 
soluble contaminants. The product was dried over anhydrous $\mathrm{MgSO}_{4}$ to yield $5.14 \mathrm{~g}$ (20.25 mols) of crude product. This was distilled at atmospheric pressure under nitrogen at $162^{\circ} \mathrm{C}$ to give $3.13 .9(12.3 \mathrm{mmols})$ in a $25 \%$ yield.

Characterization of $\mathrm{FSO}_{2} \mathrm{CF}_{2} \mathrm{CF}_{2} \mathrm{OCH}_{2} \stackrel{\mathrm{CHCH}_{2}}{\mathrm{O}}$ IR 3008 (VW), 1455 (s), 1363 (w), 1335 (m), 1244 (s), 1205 (s), 1145 (s), 1117 (s), 1040 (w), 998 (m), 801 (s), 766 (w), $653(\mathrm{~m}), 611$ (s), 548 (w); $1_{\mathrm{H}}$ NMR 2.7 (d-d), 2.9 (dd), $3.3(m), 4.0(d-d), 4.5(d-d)$; The spectra agree with literature values. 55

Preparation of $\left(\mathrm{CF}_{3} \mathrm{SO}_{2}\right)_{2} \mathrm{CKCH}_{2} \mathrm{CHCH}_{2}$ (XIII)

To a $250 \mathrm{ml}$ Pyrex glass three neck round bottom flask fitted with an addition funnel, a Teflon coated stir bar, a drying tube $\left(\mathrm{CaCl}_{2}\right)$ and a rubber septum, was added $2.81 \mathrm{~g}$ $\left(8.84\right.$ mmols) of finely ground $\left(\mathrm{CF}_{3} \mathrm{SO}_{2}\right)_{2} \mathrm{CHK}$ and $20 \mathrm{mI} \mathrm{dry}$ tetrahydrofuran (THF). The apparatus was flushed with dry nitrogen and all further addition were done with a syringe through the rubber septum. $5.00 \mathrm{ml}$ (10.0 mmols) of $\mathrm{CH}_{3} \mathrm{CH}_{2} \mathrm{MgBr}$ was injected into the addition funnel and was slowly added over 20 minutes. When gas evolution had ceased and the reaction mixture had returned to room temperature $1.02 \mathrm{ml}$ of epibromohydrin and $10 \mathrm{ml} \mathrm{THF}$ was added to the addition funnel and slowly added over 1 hour. 
The reaction mixture was stirred at reflux for two hours. The reaction mixture became very gelatinous and stirring became difficult. Most of the THF was removed by distillation, until the mixture became too thick to stir. $20 \mathrm{ml}$ diethyl ether was added and stirring was initiated again. $10 \mathrm{ml} 1 \mathrm{~N} \mathrm{HCl}$ was added to the stirred mixture, the mixture became clear. The ether was removed and the reaction vessel was rinsed twice with $10 \mathrm{ml}$ portions of ether. The ether layer was placed in a separatory funnel, $2 \mathrm{ml} 0.1 \mathrm{M} \mathrm{KOH}$ solution and $10 \mathrm{ml}$ water was added and the layers were mixed until the $\mathrm{pH}$ became neutral again. The aqueous layer was removed and the ether layer was extracted with two additional times with $0.5 \mathrm{ml} 0.1 \mathrm{M} \mathrm{KOH}$ and $5 \mathrm{ml}$ water. The aqueous layer was dried and the product was recovered in a $3.4 \mathrm{~g}$ yield.

Characterization of $\left(\mathrm{CF}_{3} \mathrm{SO}_{2}\right)_{2} \mathrm{CKCH}_{2} \mathrm{CHCH}_{2}$

IR $3083(\mathrm{VW}), 2952$ (w), 2894 (w), 1335 (m), 1313 (m), 1262 (w), 1222 (m), 1194 (s), 1125 (s), 1094 (m), 1047 (w), $1008(\mathrm{~s}), 965(\mathrm{~m}), 937(\mathrm{~m}), 834(\mathrm{w}), 762(\mathrm{w}), 653(\mathrm{~s}), 577$ $(\mathrm{s}), 507(\mathrm{~m}) ;{ }_{\mathrm{H}} \mathrm{NMR} 0.9$ (d), 1.0 (t), 1.25 (d), 1.6 (m), $1.85(m), 2.4(m), 2.6(m), 3.5(t), 3.58(d-d), 3.8(d-d)$, $4.0(m), 4.2(m), 5.57(d-d), 5.8(t), 6.3(t)$ 
1 Sylla S.; Sanchez J.-Y.; Armand M.; Electrochimica Acta.; $37(9) ; 1992 ; 1699-1701$

2 Berthier C.; Gorecki W.; Minier M.; Armand M.;

Chabagno J.M.; Rigaud P.; Solid State Ionics; 11(91); 1983

3 Dominey L.A.; Blakley T.J.; Koch; 25th IECEC Meeting; Reno; NV; Aug 16, 1990

4 Personal communication from Dr. David G. Castner, XPS studies at University of Washington

5 Nolte R.; Ledjeff K.; Bauer M.; Mülhaupt R.; Journal of Membrane Science; 83(2); 1993; 211-220

6 LeGuilianton, G.; Simonet, J.; Tetrahedron Letters; $31(22) ; 1990 ; 3149-3150$

7 Wakabayashi M.; Miyazaki Y.; Kanbara T.; Osakada K.; Yamamoto T.; Ishibashi A.; Synthetic Metals; 55(2-3); $1993 ; 1073-1078$

8 Vallee, A.; Besner, S.; Prud'Homme, J.; Electrochemica Acta; 37(9); 1992; 1579-1583

9 Bannister, D.J.; Davies, G.R.; Ward, I.M.; McIntyre, J.E.; Polymer; 25; 1984; 1291-1296

10 Sylla, S.; Sanches, J.-Y.; Armand, M.; Electrochemica Acta.;37(9); 1992; 1699-1701

11 Benrahbah, D.; Baril, D.; Sanchez, J.-Y.; Armand, M.; Gard, G.G.; J. Chem. Soc., Faraday Trans.; 89(2); $1993 ; 355-359$

12 Armand, M.B.; Chabagno, J.M.; Duclot, M.J. in East Ion Transport in Solids; Elsevier North Holland, Inc.; Vashishta, Mundy, Shenoy, Eds.; 1979; 131-136

13 Kanatzidis M.G.; Chemical and Engineering News; Dec. $3 ; 1990 ; 36-54$

14 Eisenberg, A.;Rinaudo, M.; Polymer Bulletin; 1990; 
$24 ; 69-170$

15 Eisenberg, A.; King, M.; Eds.; Ion Containing

Polymers; Academic Press, New York; 1977; p. 141-162

16 Eisenberg, A.;Rinaudo, M.; Polymer Bulletin; 1990; $24 ; 69-170$

17 Stinson, S.C.; Chemical \& Engineering News; 1982 ; March 15

18 Holliday, L.; Ed.; Ionic Polymers; John Wiley \& Sons; New York; 1975; p. 19

19 Nafion is a Du Pont registered trademark for its perfluorinated membranes; Nafion Product Bulletin; 1986

20 UK Patent ; 1,034,196; 1965

21 UK Patent; 1,034, 197; 1965

22 Eisenberg, A.; Yeager, H.L.; Eds.; Perfluorinated Ionomer Membranes; ACS Symposium Series 180, 1982 p. 217-248

23 Marx, C.L.; Caulfield, D.F.; Cooper, S.L.; Macromolecules, 1973, 6, 344

24 Eisenberg, A.; Polym. Prepr., 1988, 29(2), 429

25 Yeager, H.L.; Twardowski, Z.; Clarke, L.M.; J. Electrochem. Soc.; 1982; 129; 324

26 Twardowski, Z.; Yeager, H.L.; O'Dell, B.; J. Electrochem. Soc.; 1982; 129; 328

27 Yeager, H.L.; Steck, A.; J. Electrochem. Soc.; 1981; $128 ; 1880$

28 Yeager, H.L.; Twardowski, Z.; Clarke, L.M.; J. Electrochem. Soc.; 1982; 129; 324

29 Armand, M.B.; Chabagno, J.M.; Duclot, M.J.; East Ion Transport in Solids; Elsevier North Holland, Inc.; Amsterdam; 1979; p. 72 
31

Armand, M.B.; Polymer Electrolyte Reviews: Part 1; Elsevier Science Publishing Co.; NewYork; 1987

Armand, M.B.; Pelymer Electrelyte Reviews: Part 1; Elsevier Science Publishing Co.; NewYork; 1987

Koppel, I.A.; Taft, R.W.; Anvia, F; Zhu, S.-Z.;Hu, L.-Q.; Sung, K.-S.; DesMarteau, D.D.; Yagupolskii, L.M.; Yagupolskii, Y. L.; Ignat'ev, N.V.; Kondratenko, N.V.; Volkonskii, A.Y.; Vlasov, V.M.; Notario, R.; Maria, P.-C.; J. Am. Chem. Soc.;1994; $116 ; 3047-3057$

4 Siedle, A.R.; Newmark, R.A.; Pignolet, L.H.; Inorg. Chem.; 1986; 25; 1345-1351

5 Gramstad, T.; Haszeldine, R.N.; J. Chem. SoC; 1957; 4069-4079

Koshar, R.J.; Mitsch, R.A.; U. S. Patent; 3,776,960; 1973

7 Koshar, R.J.; Mitsch, R.A.; J. Org. Chem.; 1973; $38(19) ; 3358-3363$

Armand, M.; French Patent; PCT/FR90/00241 (WO $90 / 12000) ; 1990$

9 Armand, M.; Benrabah, D.; Sanchez, J.-Y.; Erench Patent; PCT/FR92/01024 (WO 93/09092) ; 1992

Siedle, A.R.; Gleason, W.B.; Newmark, R.A.; Organomettallics; 1986; 5; 1969-1975.

I Siedle, A.R.; Newmark, R.A.; Gleason, W.B.; J. Am. Chem. Soc.; 1986; 108; 767-773

2 Siedle, A.R.; Newmark, R.A.; Gleason, W.B.; Lamanna, W.M.; Organomettallics; 1990; 9; 1290-1295.

3 Desmarteau, D.D.; Pennington, W.T.; Sung, K.-S.; Zhu, S.-Z; Scott, R.; Eur. J. Solid State Inorg. Chem.; $1991 ; 28(5) ; 905-917$

4 Turowsky, L; SeppeIt, K.; Inorg. Chem.; 1988; 27; 2135-2137 
45 Sung, K.; Dissertation: Synthesis of Fluoropolymers containing Strongly Acidic Sulfonimide functional Groups, Chemistry of

Bis(trifluoromethylsulfonyl)methane, and Layered Structures of $\alpha, \omega-D i f u n c t i o n a l$ Salts; Clemson University; 1992

46 Zhu, S.-Z.; Heteroatom Chemistry; 1994; 5(1);9-18

47 Zhu, S.-Z.; Chen, Q.-y.; J. Chem. Soc., Chem. Commun.; 1990; 1459-146

48 Zhu, S.-Z.; Synthesis; 1994; March; 261-263

49 Berg, E.P.; U. S. Patent; 4,043,967; 1977

50 U.S. Patent; $3,776,960 ; 1971$

51 Hudlicky, M.; Chemistry of organic Eluorine Compounds; Elsevier Scientific; Amsterdam; 1994

52 Hamel, N.N.; Gard, G.L.; Journal of Eluorine Chemistry; 68; 1994; 253-259

53 Silverstein, R.M.; Bassler, G.C.; Morrill, T.C.; Spectrometric Indentification of organic compounds; John Wiley and Sons, Inc.; New York; 1991; p 111

54 Hudlicky, M.; Chemistry of organic Eluorine Compounds; Elsevier Scientific; Amsterdam; 1994

55 Chen, L.-E.; Mohtasham, J.; Gard, G.L.; Journal of Fluorine Chemistry; 46; 1990; 39-56 
APPENDIX A

INERARED SPECTRA 


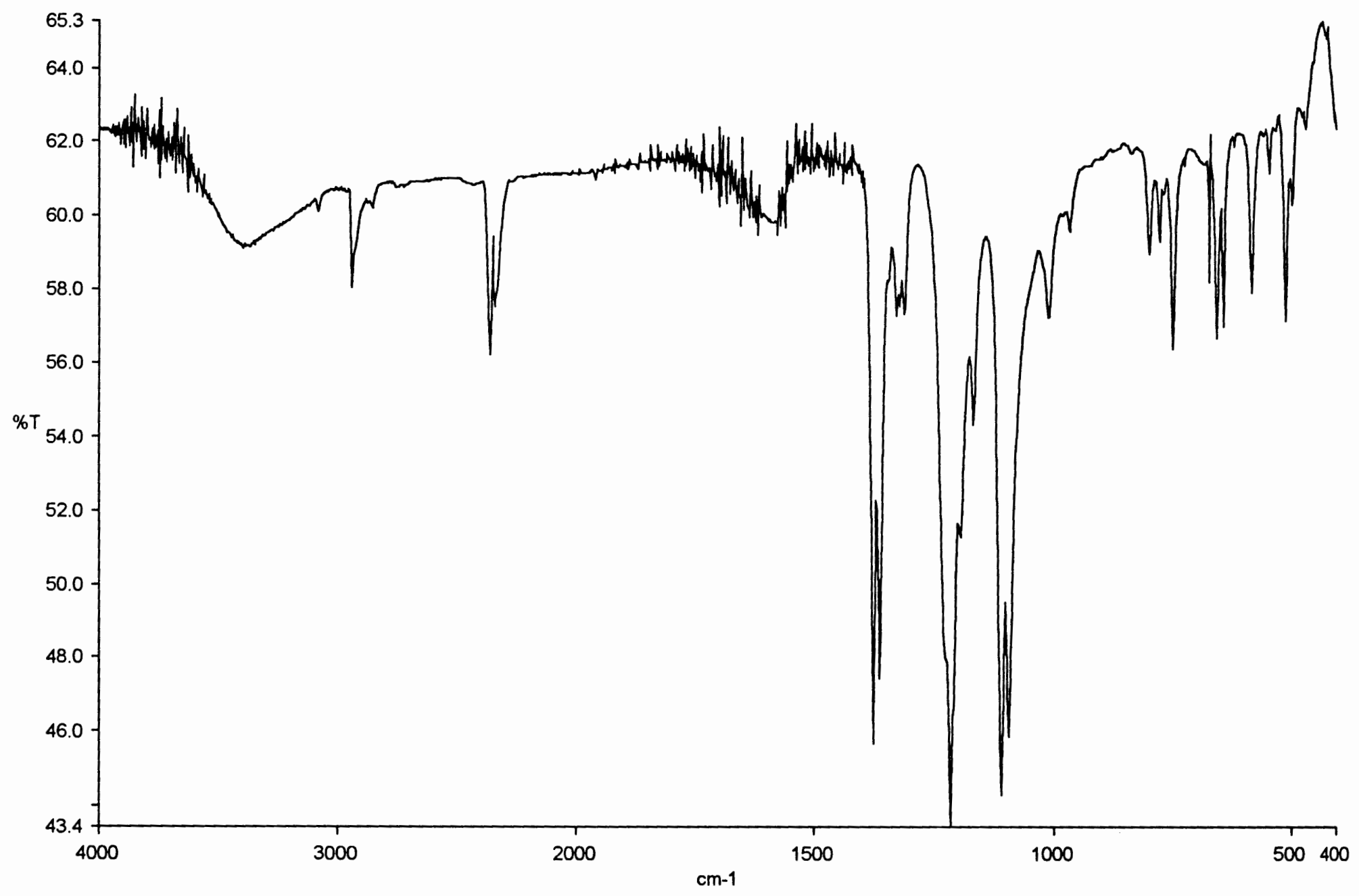

Figure 9: IR spectra of $\left.\left[\left(\mathrm{CF}_{3} \mathrm{SO}_{2}\right){ }_{2} \mathrm{CH}\right)\right]_{2} \mathrm{Hg}$ salt 


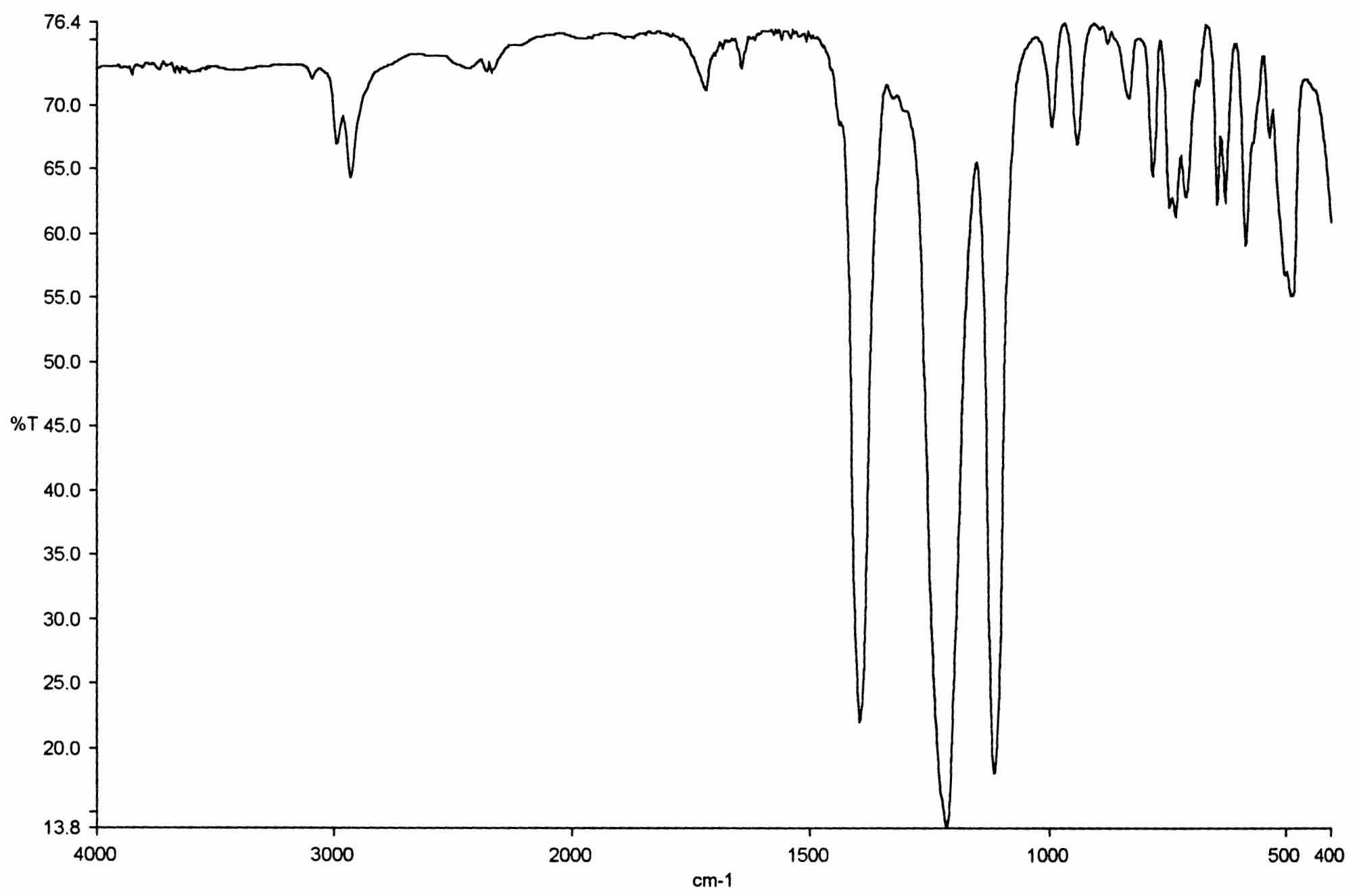

Figure 10: IR spectra of $\left(\mathrm{CF}_{3} \mathrm{SO}_{2}\right)_{2} \mathrm{CHCH}_{2} \mathrm{CH}=\mathrm{CH}_{2}$ 


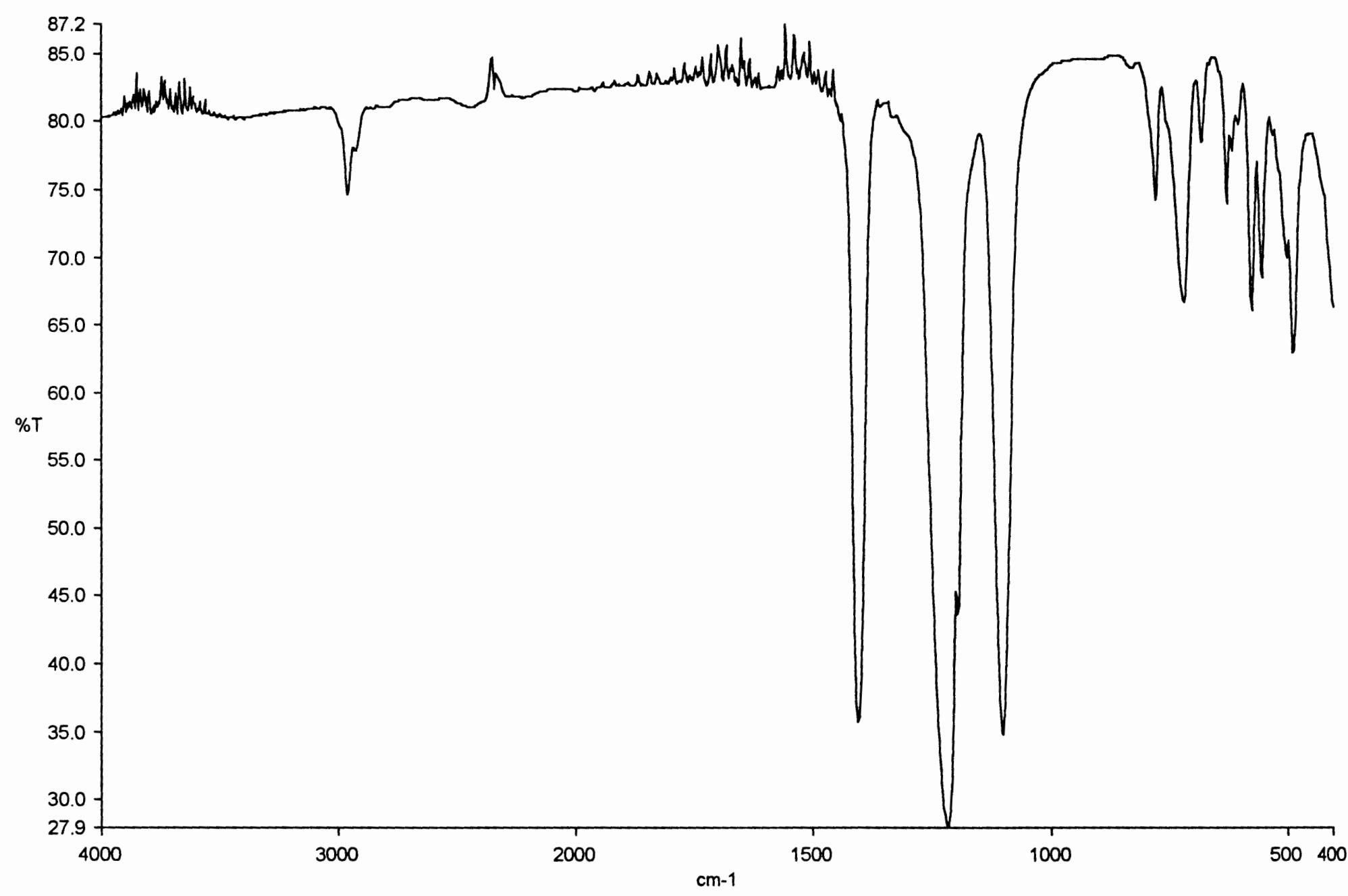

Figure 11: IR Spectra of $\left(\mathrm{CF}_{3} \mathrm{SO}_{2}\right)_{2} \mathrm{CHBr}$ 


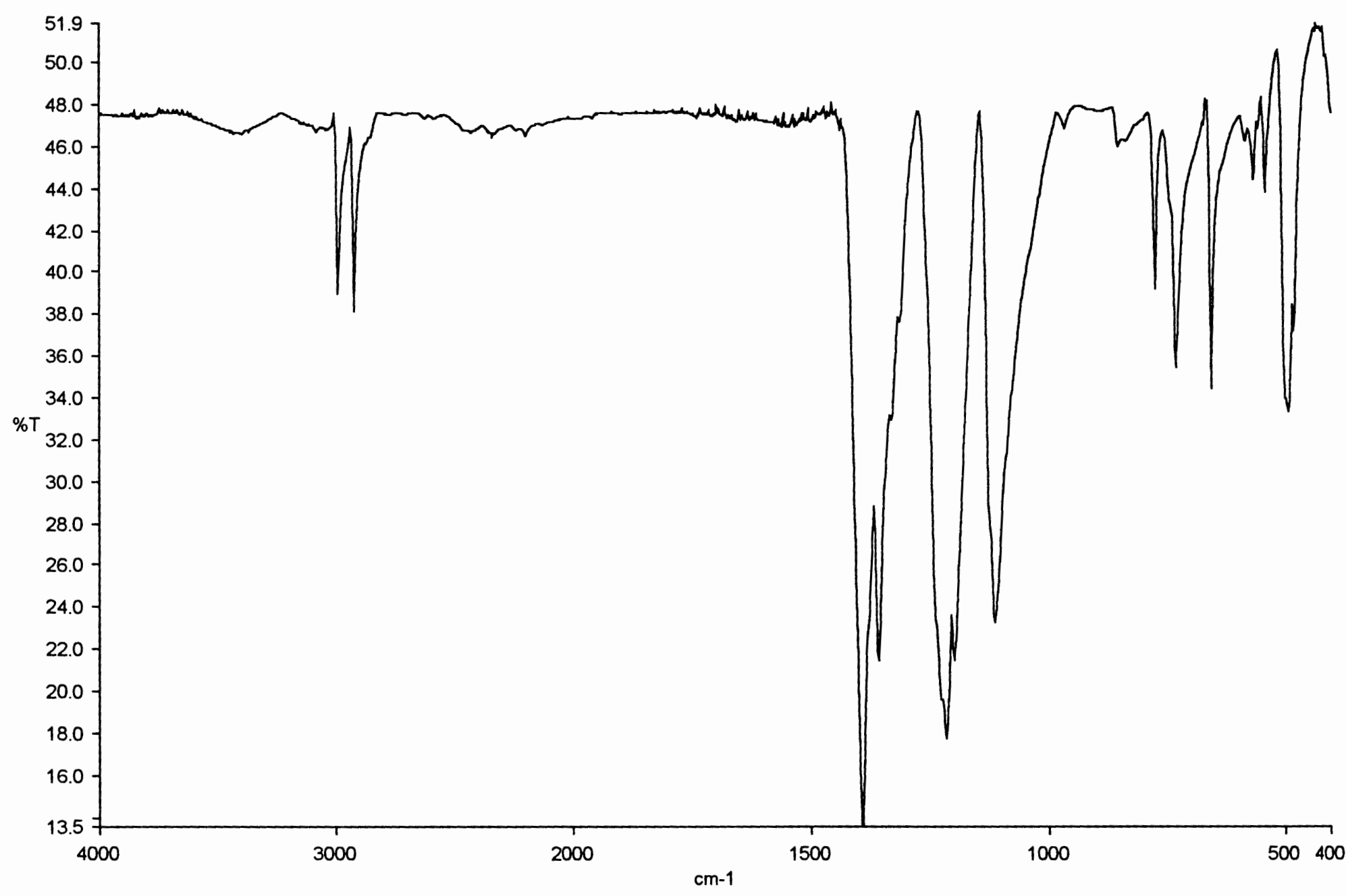

Figure 12: IR Spectra of $\left(\mathrm{CF}_{3} \mathrm{SO}_{2}\right)_{2} \mathrm{CH}_{2}$ 


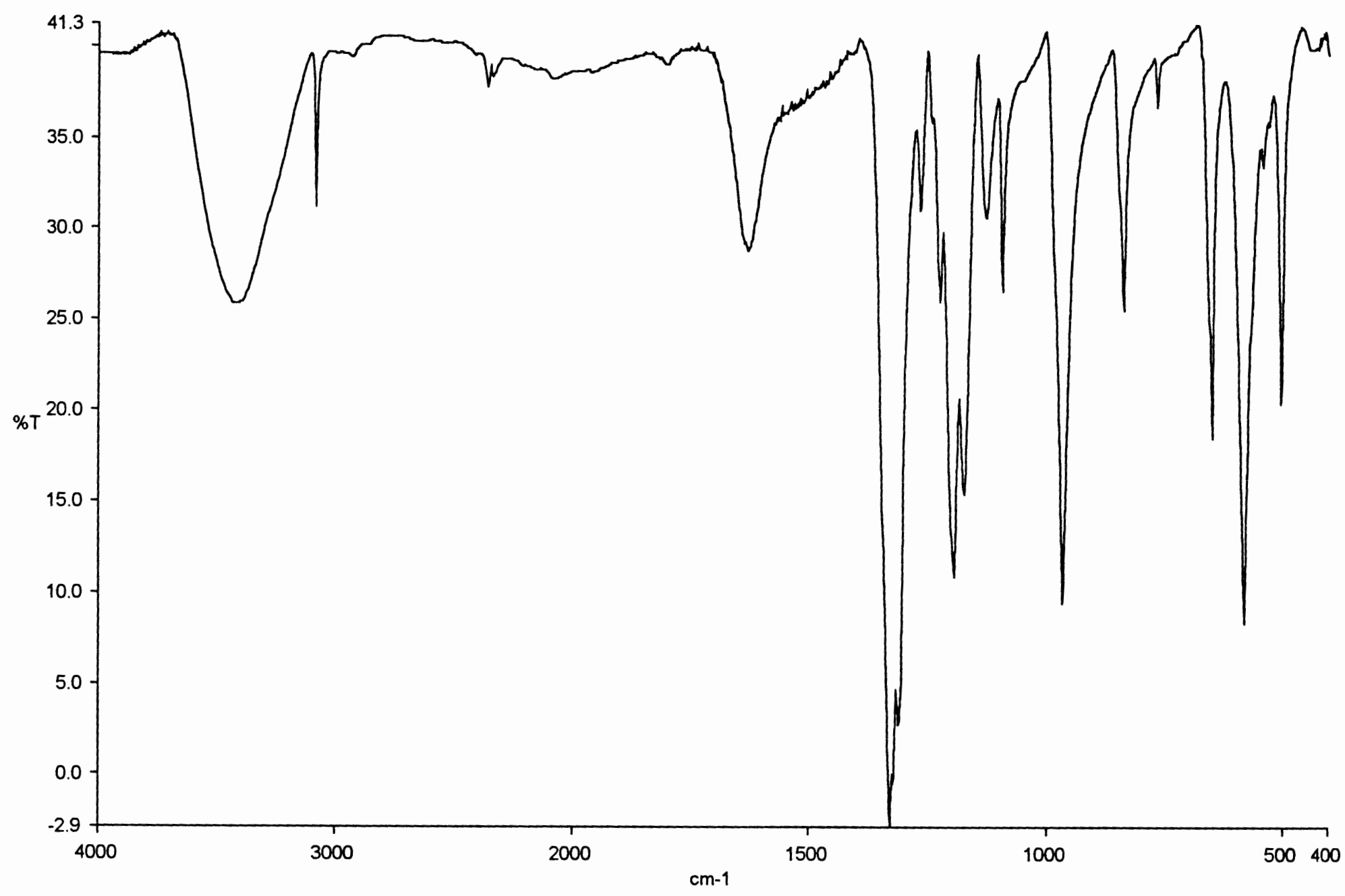

Figure 13: IR spectra of $\left(\mathrm{CF}_{3} \mathrm{SO}_{2}\right)_{2} \mathrm{CHLi}$ 


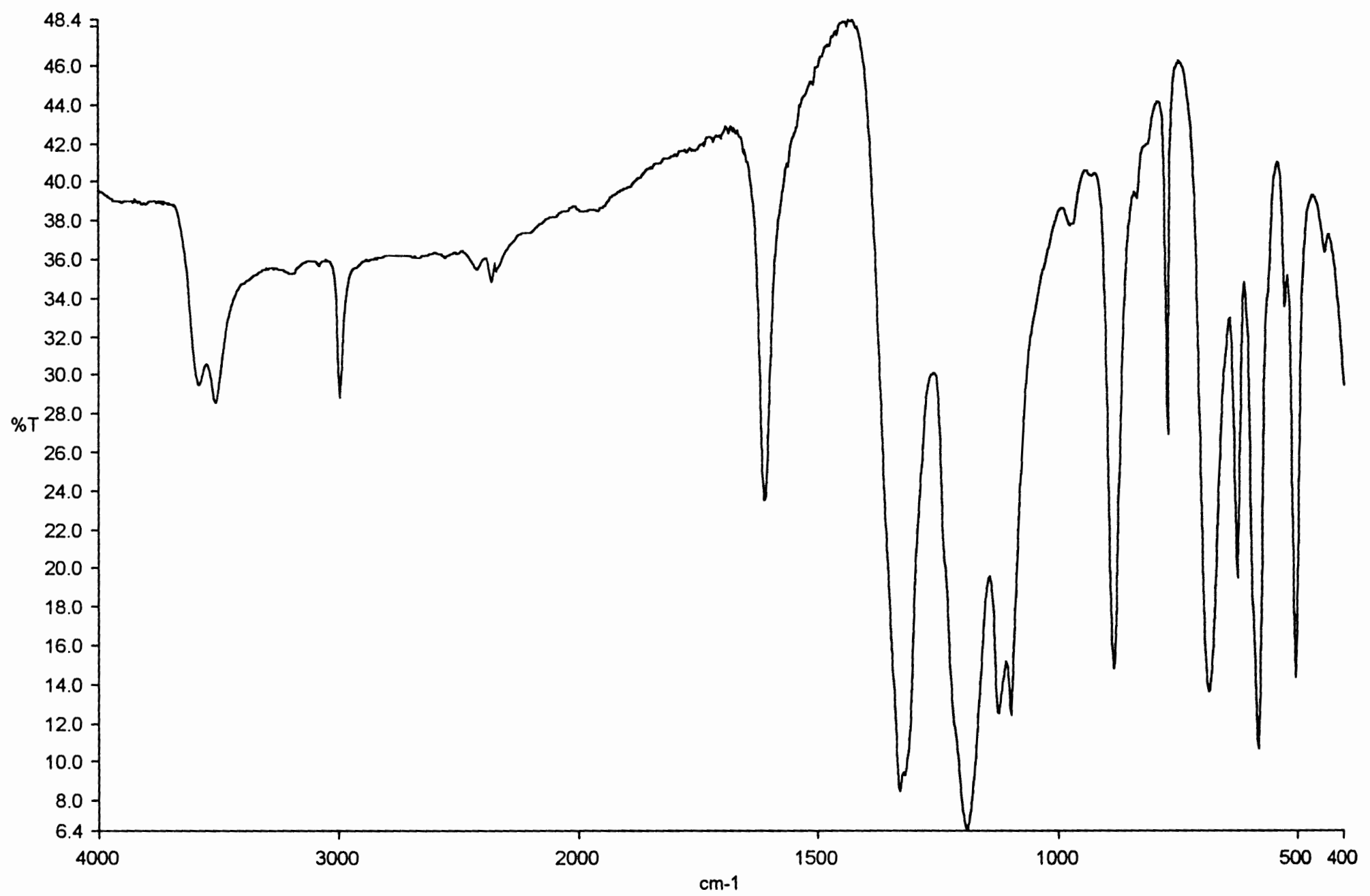

Figure 14: IR Spectra of $\left(\mathrm{CF}_{3} \mathrm{SO}_{2}\right)_{2} \mathrm{CHAg}$ 


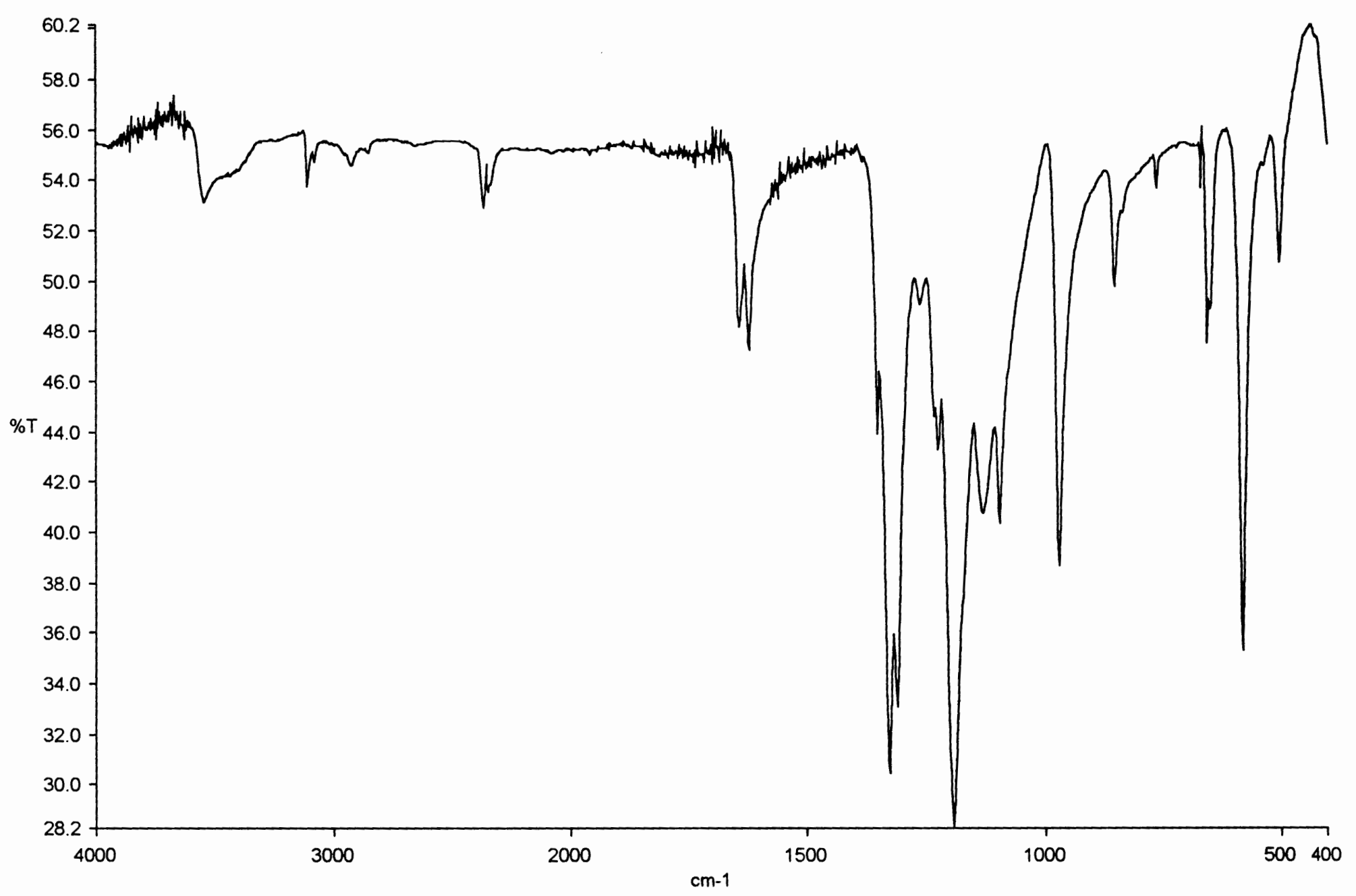

Figure 15: IR spectra of $\left.\left[\left(\mathrm{CF}_{3} \mathrm{SO}_{2}\right)_{2} \mathrm{CH}\right)\right]_{2} \mathrm{Ca}$ 


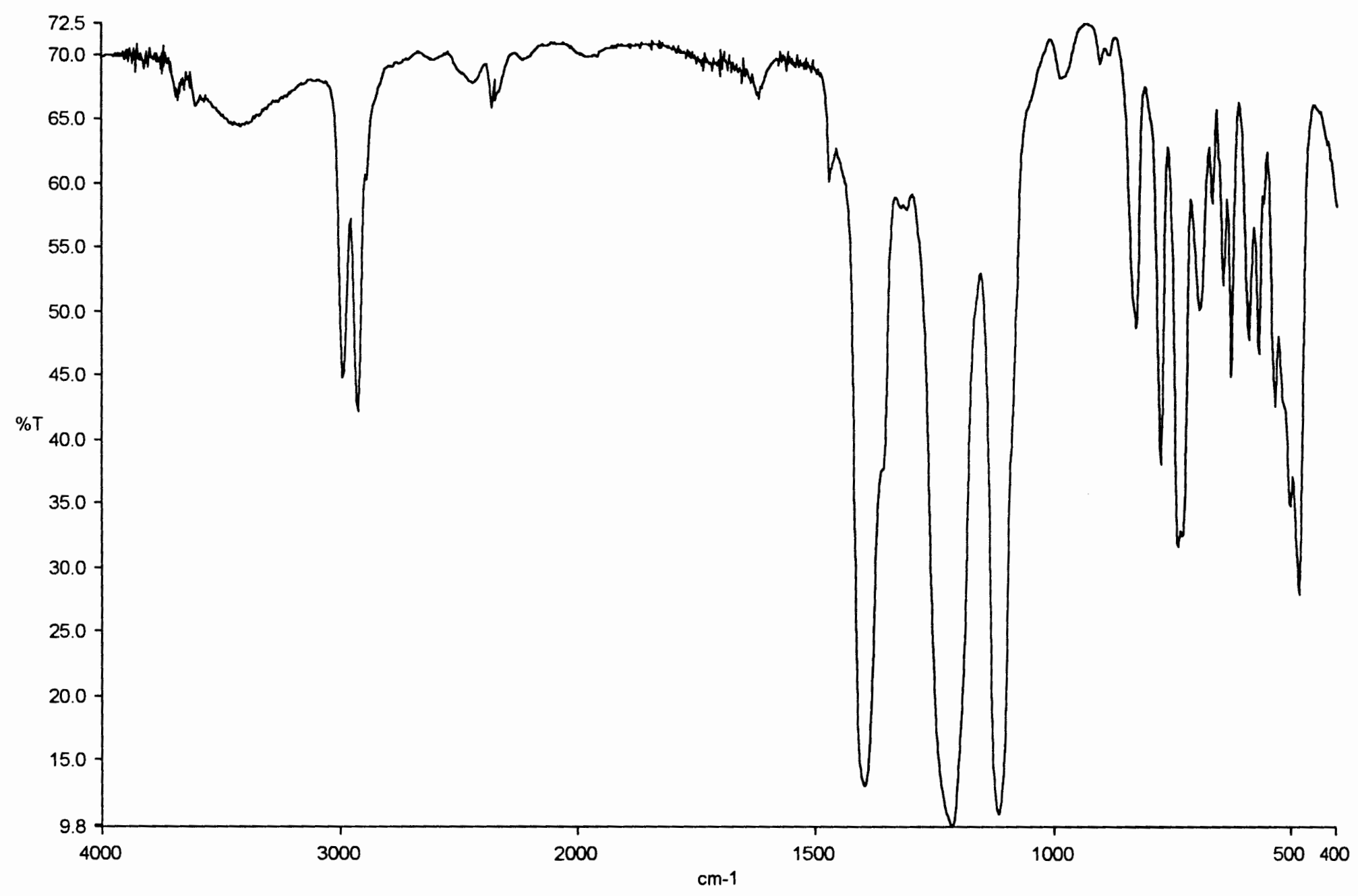

Figure 16: IR spectra of $\left(\mathrm{CF}_{3} \mathrm{SO}_{2}\right)_{2} \mathrm{CHCH}_{2} \mathrm{CH}_{2} \mathrm{CH}_{3}$ 


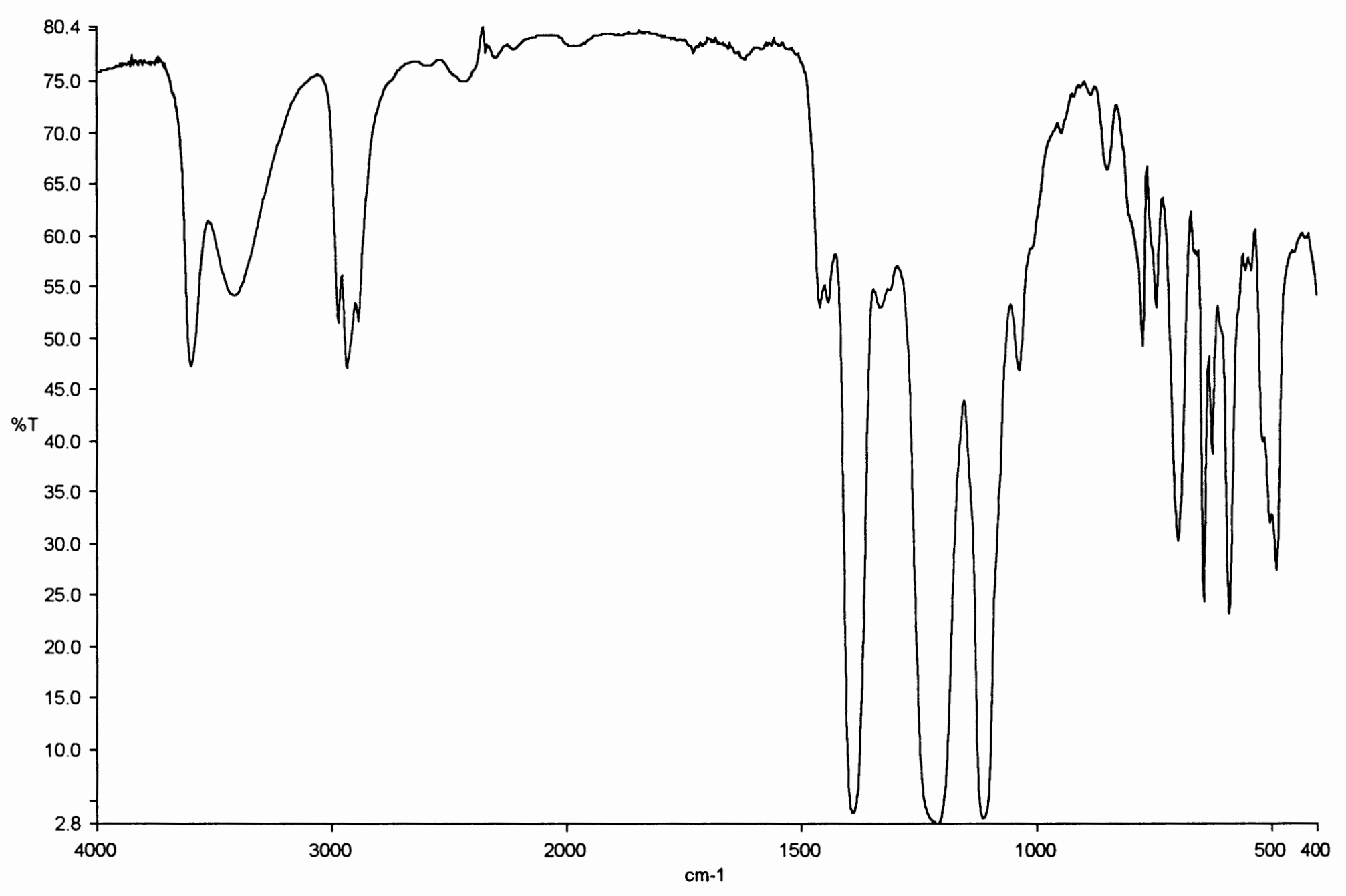

Figure 17: IR spectra of $\left(\mathrm{CF}_{3} \mathrm{SO}_{2}\right){ }_{2} \mathrm{CHCH}_{2} \mathrm{CH}(\mathrm{OH}) \mathrm{CH}_{2} \mathrm{Cl}$ 


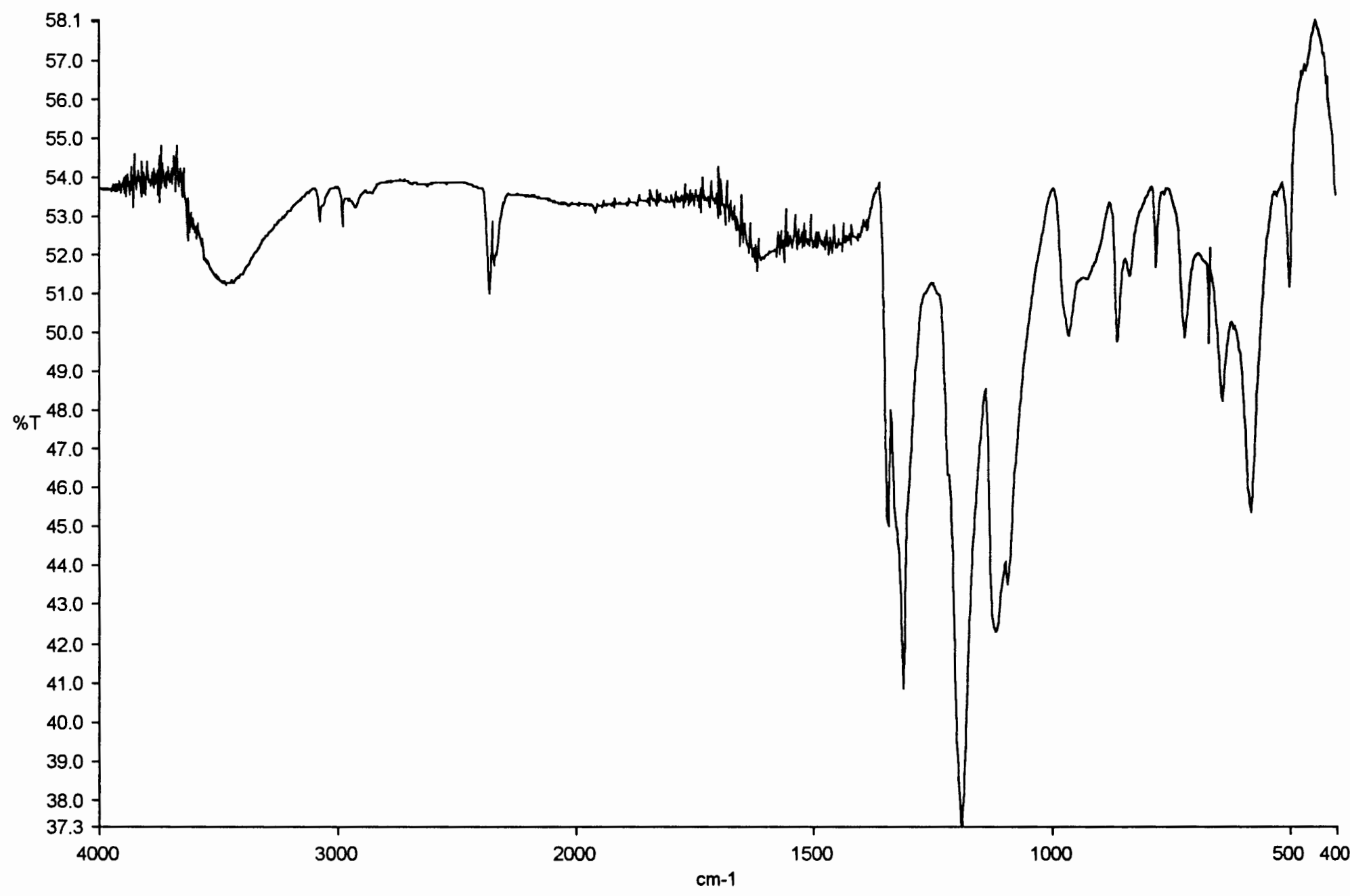

Figure 18: IR Spectra of $\left.\left[\left(\mathrm{CF}_{3} \mathrm{SO}_{2}\right)_{2} \mathrm{CH}\right)\right]_{2} \mathrm{Zn}$ 


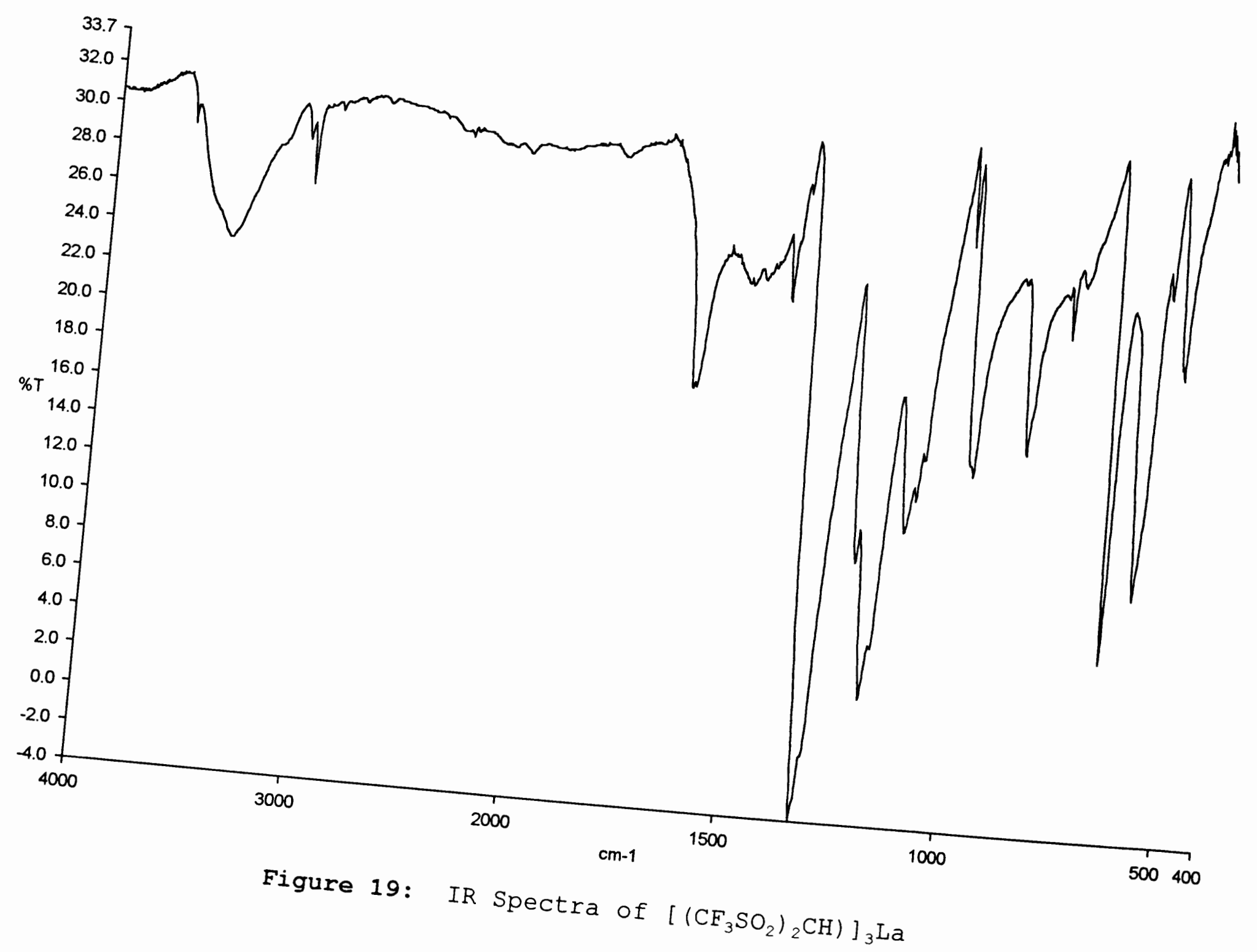




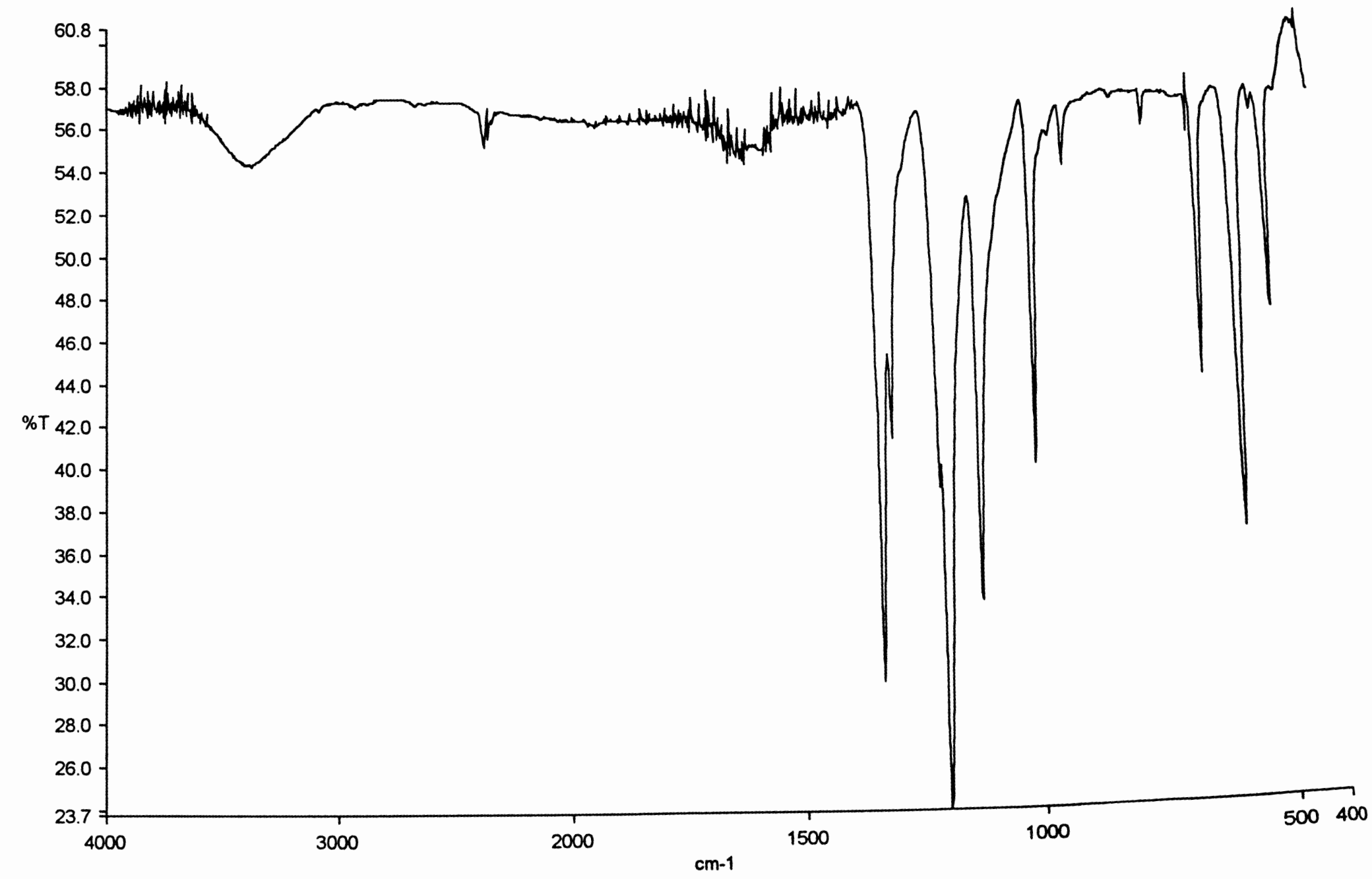

Figure 20: IR Spectra of $\left(\mathrm{CF}_{3} \mathrm{SO}_{2}\right)_{2} \mathrm{CBrK}$ 


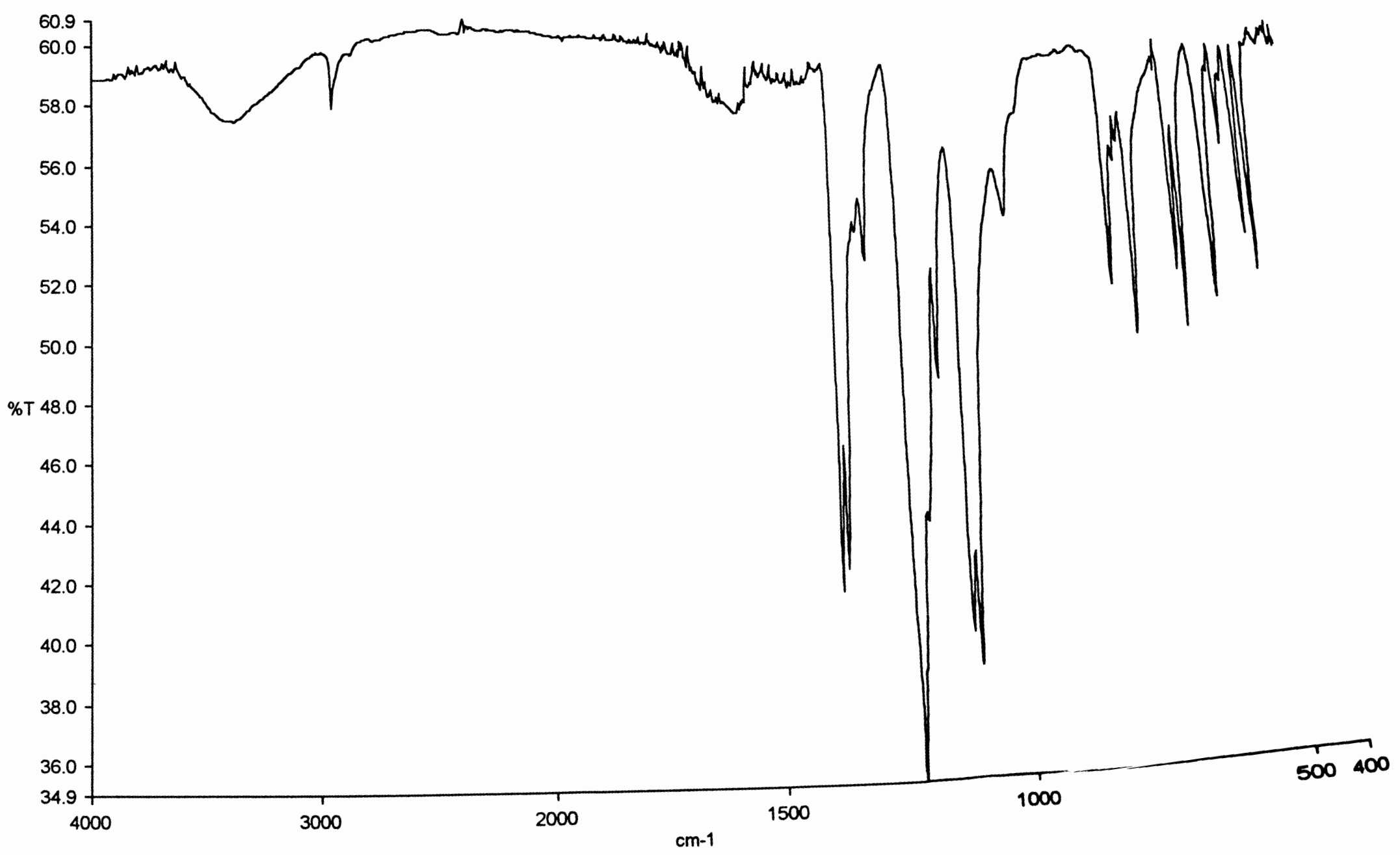

Figure 21: IR spectra of $\left(\mathrm{CF}_{3} \mathrm{SO}_{2}\right)_{2} \mathrm{CH}(\mathrm{HgBr})$ 


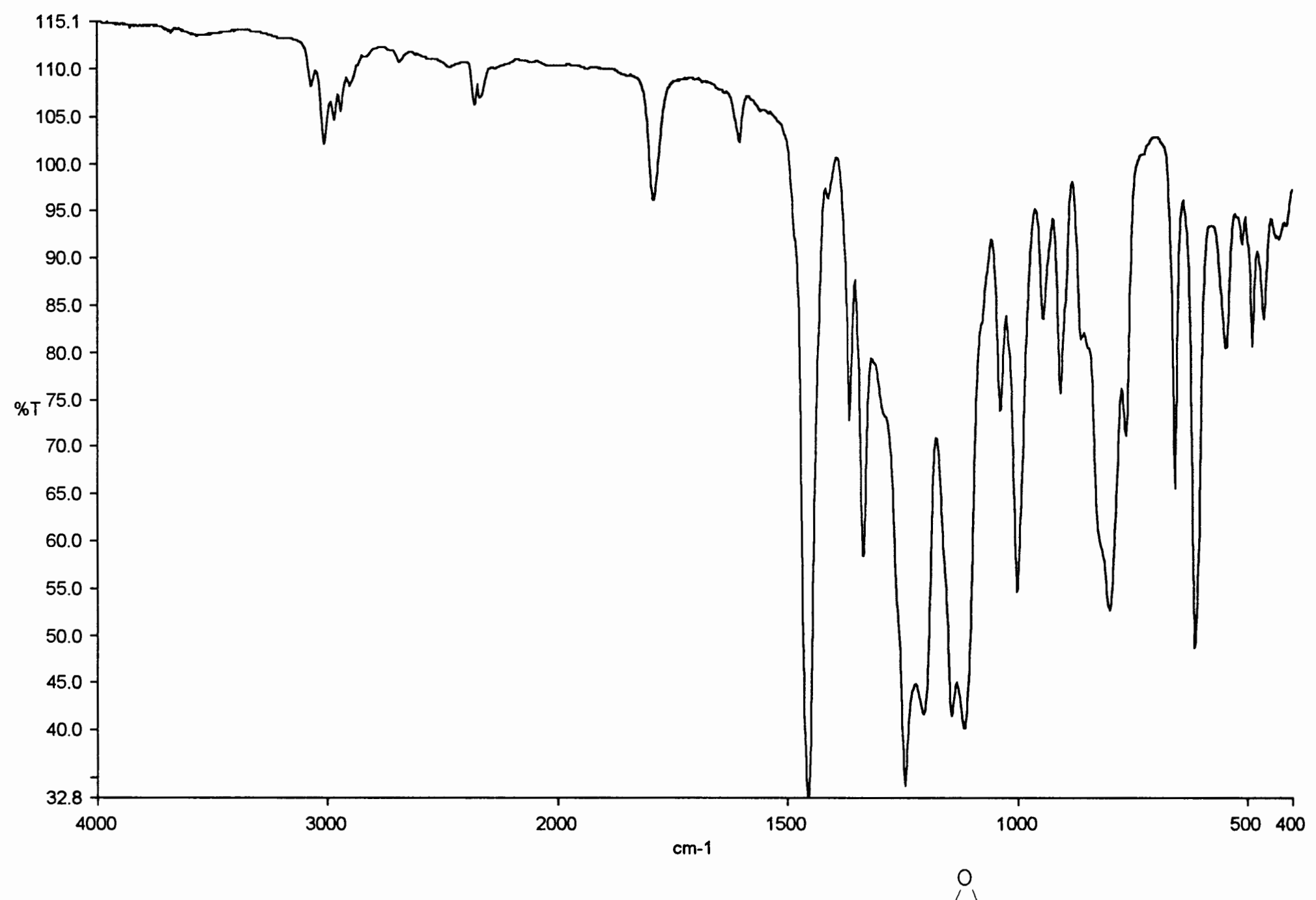

Figure 22: IR spectra of $\mathrm{FSO}_{2} \mathrm{CF}_{2} \mathrm{CF}_{2} \mathrm{OCH}_{2} \mathrm{CHCH}_{2}$ 